Universidade de Brasília Instituto de Ciências Biológicas

Departamento de Biologia Celular

Pós-Graduação em Biologia Molecular

Efeito do modulador epigenético 5-AZA-2'desoxi-citidina dos genes e a produção de celulases e xilanases pelo fungo termofílico Humicola grisea var. thermoidea cultivado em resíduos agrícolas

João Heitor Colombelli Manfrão Netto 

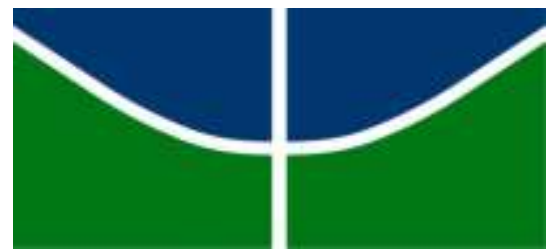

Universidade de Brasília Instituto de Ciências Biológicas

Departamento de Biologia Celular

Pós-Graduação em Biologia Molecular

\section{Efeito do modulador epigenético 5-Aza-2' -desoxi- citidina dos genes e a produção de celulases e xilanases pelo fungo termofílico Humicola grisea var. thermoidea cultivado em resíduos agrícolas}

João Heitor Colombelli Manfrão Netto

Orientador: Prof. Dr. Marcio José Poças Fonseca

Dissertação apresentada ao Departamento de Biologia Celular do Instituto de Ciências Biológicas da Universidade de Brasília, como requisito parcial à obtenção do grau de Mestre em Biologia Molecular.

Brasília, 2016 
Trabalho desenvolvido nos Laboratórios de Biologia Molecular e de Regulação Gênica e Mutagênese da Universidade de Brasília (UnB) sob orientação do Prof. Dr. Marcio José Poças Fonseca. 


\section{BANCA EXAMINADORA}

\section{Titulares:}

Orientador:

Dr. Marcio José Poças Fonseca

Departamento de Genética e Morfologia (GEM/IB)

Universidade de Brasília - UnB

\section{Titulares}

Dra. Nádia Skorupa Parachin

Departamento de Biologia Celular (CEL/IB)

Universidade de Brasília - UnB

Dra. Fabrícia Paula de Faria

Instituto de Ciências biológicas II

Universidade Federal de Goiás -UFG

\section{Suplente:}

Dr. Edivaldo Ximenes Ferreira Filho

Departamento de Biologia Celular (CEL/IB)

Universidade de Brasília-UnB 
"Eu tentei 99 vezes e falhei, mas na centésima tentativa eu consegui"

(Albert Einstein) 


\section{AGRADECIMENTOS}

Primeiramente agradeço a Deus por me dar forças para sempre prosseguir, não importando as dificuldades encontradas no caminho.

Agradeço a toda minha família pelo apoio, principalmente a minha mãe que sempre me apoiou na escolha de vida que fiz e me deu condições para seguir em meu sonho.

Agradeço aos meus amigos, que mesmo não sabendo nada do que faço sempre ficam admirados e curiosos quando falo sobre minha pesquisa ou sobre biologia, principalmente ao João Ricardo Cabral.

Um agradecimento especial ao meu melhor amigo Yuri Barros por todos os momentos de reflexões e conversas sobre a vida, com certeza cresci muito como homem nessas introspecções.

Ao meu orientador Professor Márcio Poças por todo o ensinamento, paciência e pela oportunidade de realizar um sonho meu. Muito obrigado por tudo professor.

Ás meninas do nosso laboratório, Camila, Fernanda, Cássia e Juliana, por todo o apoio na hora de fazer os ensaios enzimáticos, nos experimentos de indução e todos os demais experimentos que realizamos. Sem vocês não teria conseguido concluir este trabalho, muito obrigado meninas.

Ao pessoal do Lab3: Lorena, Paty, Fernanda, Rayka, Daniel, Fabian, Marco e Fabiana, por sempre em ajudarem tirando minhas dúvidas e fornecendo reagentes e materiais para 0 desenvolvimento deste trabalho.

Ao pessoal do Laboratório de Enzimologia, principalmente ao Professor Edivaldo e a Antonielly pela ajuda nas análises de proteínas e também pelas dúvidas respondidas quando precisei.

Agradeço as Professores do Departamento de Genética e Morfologia, Professora Rosana, Professora Nilda, Professor Fernando e todos os demais professores do Departamento por tornar o meu ambiente de trabalho tão agradável e receptivo.

Um agradecimento especial a Ana Carolina Alipaz, que permaneceu ao meu lado $90 \%$ do meu mestrado, mas que no final não pode ver como ele foi concluído. Mas não tenho dúvidas que sem você eu não teria conseguido chegar até aqui. Muito obrigado.

Queria agradecer a Natália pelo carinho e atenção no momento de encerramento do meu mestrado. Sua ajuda ficará guardada pra sempre no meu coração.

Por fim, agradeço ao primeiro amigo que fiz no laboratório, o Henrique, que me ensinou sobre o projeto no inicio do mestrado e sobre os experimentos que iriamos desenvolver. Ele 
sempre foi uma pessoa esforçada e competente, e que sem dúvidas se tornaria um excelente pesquisador, por isso dedicado este trabalho a você Henrique.

À Universidade de Brasília e ao Programa de Pós-Graduação em Biologia Molecular. À Capes e ao CNPQ pelo apoio financeiro. 


\section{$\underline{\text { ÍNDICE }}$}

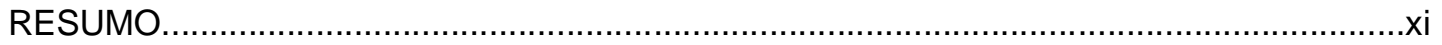

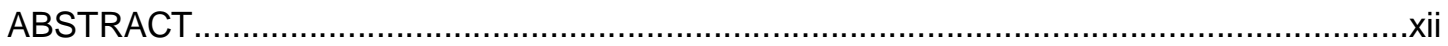

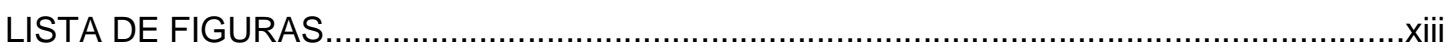

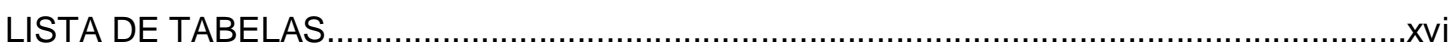

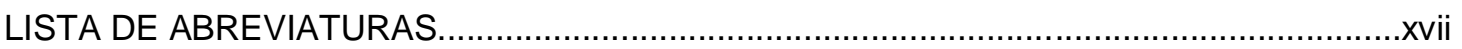

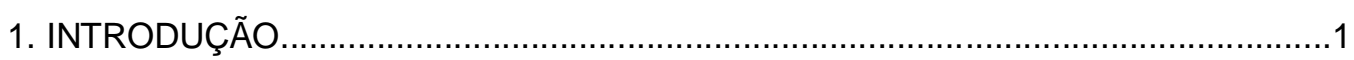

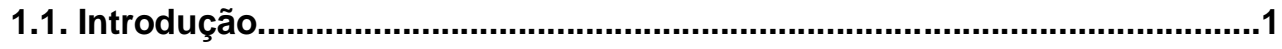

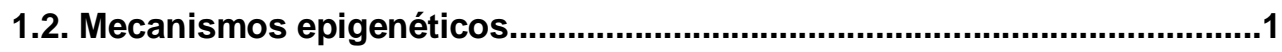

1.3. Metilação do DNA e a regulação gênica.......................................................

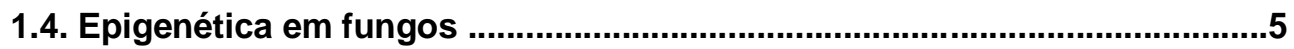

1.5. Metilação do DNA em fungos...................................................................6

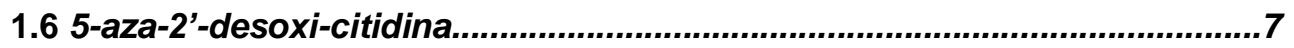

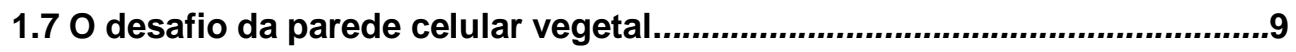

1.8 Fungos e sua importância industrial............................................................12

1.9 Sistema celulolítico do fungo Humicola grisea var. thermoidea..................15

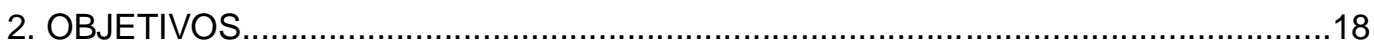

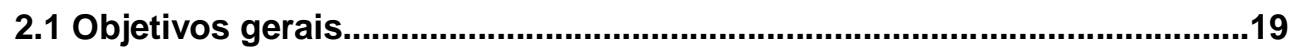

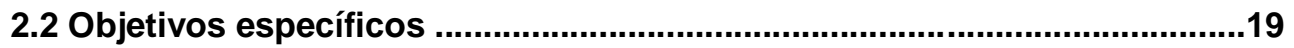

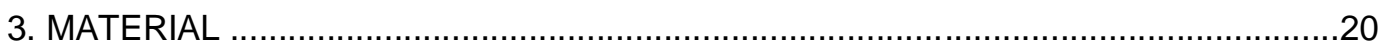

3.1. Meios para crescimento e indução da produção enzimática pelo

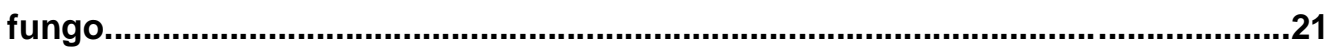

3.2. Soluções para medição da atividade enzimática......................................23

3.3. Soluções para gel de RNA (Materiais RNAse-free)......................................24 
4.1. Indução da produção enzimática pelo fungo na presença dos diferentes substratos lignocelulósicos e em diferentes concentrações de 5-aza-2'desoxicitidina..

4.2. Droga: 5-aza-2'-desoxicitidina (5-AZA)..................................................25

4.3. Medidas de atividade enzimática..............................................................26

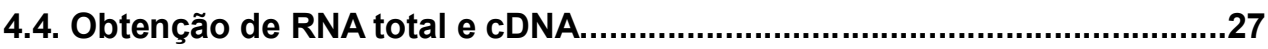

4.5. Quantificação de acúmulo de transcritos por RT-qPCR.........................28

4.6. Quantificação de proteínas....................................................................29

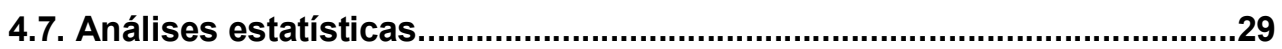

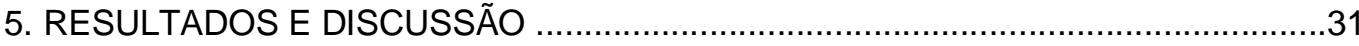

5.1. Determinação da sensibilidade do fungo H.grisea à droga .A..................31

5.2. Seleção dos substratos a serem utilizados para indução enzimáti..........31

5.3. Curvas de indução enzimática do fungo $H$. grisea.. . .33

5.4. Determinação da atividade de CMCase nos sobrenadantes de cultura de $\boldsymbol{H}$.grisea crescido na presença de 5-AZA.

5.5. Determinação da atividade de xilanase nos sobrenadantes de cultura de $\boldsymbol{H}$. grisea crescido na presença de 5-AZA. 39

5.6. Efeito da 5-AZA na produção de proteínas .42

5.7. Efeito da 5-AZA sobre 0 acúmulo de transcritos de genes de endoglicanase. .43

5.8. Efeito da 5-AZA sobre 0 acúmulo de transcritos de genes de

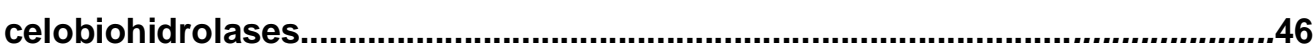

5.9. Efeito da 5-AZA sobre 0 acúmulo de transcritos do gene bg/4.

5.10. Efeito da 5-AZA sobre 0 acúmulo de transcritos de genes de endoxilanases. .49

5.11. Correlação do efeito da 5-AZA nos ensaios enzimáticos e no acúmulo de transcritos dos diferentes genes analisados. .51 
6. CONCLUSÃO E PERSPECTIVAS

7. REFERÊNCIAS BIBLIOGRÁFICAS. 


\section{RESUMO}

Humicola grisea var. thermoidea é um ascomiceto termofílico produtor de enzimas lignocelulolíticas, principalmente celulases e xilanases, sendo proposto para utilização na bioconversão de resíduos agrícolas em produtos úteis. A metilação de DNA é um mecanismo epigenético de regulação gênica que tem sido amplamente estudado, sendo geralmente associado à repressão transcricional. Enzimas DNA metiltransferases (DNMsT) são responsáveis por realizar a metilação do DNA. Drogas que inibem as DNMTs são frequentemente utilizadas em estudos de patologias como o câncer, entre outros, porém nada se sabe a respeito de um possível efeito na produção, atividade ou secreção de enzimas hidrolíticas de fungos, assim como na regulação da expressão dos respectivos genes.

No presente trabalho, avaliou-se o efeito da droga 5-aza-2'-desoxicitidina (5-AZA; inibidora da ação de DNMTs), em duas concentrações (25 e $50 \mu \mathrm{M})$, sobre a atividade enzimática secretada e os níveis de transcritos de genes de celulase e xilanase de $H$. grisea crescido em diferentes resíduos agrícolas [bagaço de cana de açúcar explodido a vapor (BCA), feno moído e farelo de trigo (FT)], e em glicose. A presença de 5-AZA mostrou-se relacionada a um aumento de atividade de CMCase após crescimento do fungo $H$. grisea em FT 12 h/50 $\mu \mathrm{M}(67,15 \%)$ e em glicose $2 \mathrm{~h} / 50 \mu \mathrm{M}(47,62 \%)$. Uma diminuição dessa atividade foi verificada quando do crescimento do fungo em BCA $96 \mathrm{~h}$ em 5-AZA 25 (29,12\%) e $50 \mu \mathrm{M}(29,95 \%)$. A atividade de xilanase secretada por $H$. grisea, na presença de 5-AZA, diminuiu em cultivo em BCA/96 h 25 (32,39\%) e $50 \mu \mathrm{M}(30,59 \%)$ e FT 2 h/50 $\mu \mathrm{M}$ (59,72\%). Porém, em crescimento em FT por 12 e $96 \mathrm{~h}$, na concentração de $25 \mu \mathrm{M}$, a 5-AZA levou a um aumento na atividade xilanolítica (19,97\% e $25,35 \%$, respectivamente). A produção de proteínas totais secretadas para o sobrenadante não foi afetada pelo crescimento de $H$. grisea em presença de 5-AZA, independentemente do substrato empregado como fonte de carbono. A 5-AZA afetou diferencialmente a expressão dos genes de celulase eg/1, cbh.1.1, cbh1.2 e de xilanase $x y n 1 \mathrm{e}$ xyn2 de H. grisea, provocando diminuição ou aumento do acúmulo de transcritos, dependendo da concentração utilizada e do resíduo agrícola empregado para o crescimento. Já em crescimento em glicose, a 5-AZA mostrou-se capaz de superar a repressão catabólica e aumentar os níveis dos transcritos de eg/1, cbh1.1, cbh1.2 e xyn2. O acúmulo de transcritos dos genes de celulase eg/4 e bg/4 não foi alterado em nenhuma condição experimental.

Os dados desse trabalho indicam, pela primeira vez na literatura científica, que a modulação epigenética, no nível de metilação do DNA, exerce papel na regulação da expressão dos genes de celulase e xilanase de fungos e que pode ser empregada visando à otimização de processos biotecnológicos de conversão de resíduos agrícolas em produtos de maior valor agregado.

Palavras-chave: Epigenética; Humicola grisea var.thermoidea ; 5-aza-2'-desoxicitidina 


\section{ABSTRACT}

Humicola grisea var. thermoidea is a thermophilic ascomycete that produces lignocellulolytic enzymes, particularly cellulases and xylanases and, in this view, it is proposed as a bioagent for the conversion of agricultural residues into useful byproducts. DNA methylation is an epigenetic mechanism of gene regulation that has been widely studied, being generally associated with transcriptional repression. DNA methyltransferases (DNMTs) are the enzymes responsible for performing DNA methylation. Drugs that inhibit DNMTs activity are frequently employed in studies of diseases such as cancer, amongst others, but nothing is known about a possible effect on the production, secretion, or activity of fungal hydrolytic enzymes, as well as on the regulation of expression the respective genes.

In this study we evaluated the effect of the drug 5-aza-2'-deoxycytidine (5-AZA; an inhibitor of DNMTs activity) at two concentrations (25 and $50 \mu \mathrm{M})$ on secreted enzyme activity and on the levels of xylanase and cellulase gene transcripts from $H$. grisea grown in different agricultural residues [steam exploded sugarcane bagasse (BCA), ground hay and wheat bran $(\mathrm{FT})$ ], as well as in glucose, as the sole carbon source. The presence of 5-AZA led to an increase in CMCase activity after $\mathrm{H}$. grisea was grown in FT $12 \mathrm{~h} / 50 \mu \mathrm{M}(67,18 \%)$ and glucose $2 \mathrm{~h} / 50 \mu \mathrm{M}(47,62 \%)$. A decrease in this activity was observed when the fungus was grown in BCA in the presence of $25(29,12 \%)$ or $50 \mu \mathrm{M}(29,95 \%) 5-A Z A$ for $96 \mathrm{~h}$. The xylanase activity secreted by $H$. grisea grown in the presence of 5-AZA decreased upon cultivation on BCA for $96 \mathrm{~h} 25(32,39 \%)$ and $50 \mu \mathrm{M}(30,59 \%)$ and on FT 2 h/50 $\mu \mathrm{M}(59,72 \%)$. However, upon growth on FT for 12 and $96 \mathrm{~h}$, at a concentration of $25 \mu \mathrm{M}, 5$-AZA led to an increased xylanolytic activity $(19,97 \%$ and $25,35 \%$, respectively). The production of total secreted proteins into the supernatant was not affected by $H$. grisea growth in the presence of 5-AZA, regardless of the substrate used as the carbon source. 5-AZA differentially affected the expression of $\mathrm{H}$. grisea eg/1, cbh1.1 and cbh1.2 cellulase genes, and of the $x y n 1$ and $x y n 2$ xylanase genes, causing decreased or increased accumulation of transcripts, depending on the concentration used and on the agricultural residue employed to support fungal growth. Notably, when $H$. grisea was grown on glucose as the sole carbon source, 5-AZA overcame catabolite repression and increased the levels of the eg/1, cbh1.1, cbh1.2 and $x y n 2$ transcripts. The accumulation of transcripts of the eg/4 and $b g / 4$ cellulase genes was not altered under any experimental condition.

Our data indicate that epigenetic modulation, at the level of DNA methylation, plays a role in regulating the expression of fungal cellulase and xylanase genes. This information is pioneering in the scientific literature and can be used with the aim of optimizing biotechnological processes for the conversion of agricultural wastes into valuable products.

Keywords: Epigenetics; Humicola grisea var.thermoidea; 5-aza-2'-deoxycytidine 


\section{LISTA DE FIGURAS}

Figura 1. Representação esquemática da eucromatina e heterocromatina...................2

Figura 2. Representação esquemática da estrutura das 5 DNMTs já descritas ..........4

Figura 3. Formação da heterocromatina nas RIPs em N.crassa.................................6

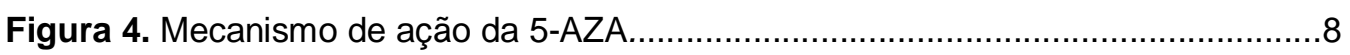

Figura 5. Representação esquemática da estrutura da parede celular vegetal ............9

Figura 6. Representação esquemática da estrutura da celulose e enzimas responsáveis por sua degradação. 10

Figura 7. Representação esquemática da estrutura química da lignina. 11

Figura 8. Representação esquemática estrutura da xilana e enzimas que atuam em sua degradação 12

Figura 9. Árvore filogenética do gênero Humicola...................................................13

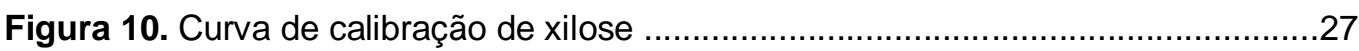

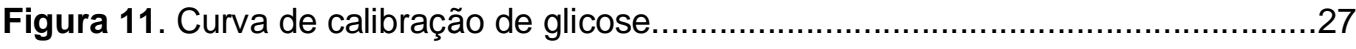

Figura 12. Curva de crescimento em meio sólido ágar-aveia do fungo $H$. grisea na presença de diferentes concentrações da droga 5-AZA

Figura 13. Atividade de CMCase do fungo $H$. grisea cultivado na presença de diferentes substratos e da droga 5-AZA. .32

Figura 14. Atividade de xilanase do fungo $H$. grisea cultivado na presença de diferentes substratos e da droga 5-AZA.

Figura 15. Atividades de CMCase e xilanase do fungo $H$. grisea ao longo de $120 \mathrm{~h}$ na presença de BCA como única fonte de carbono. 34

Figura 16. Atividades de CMCase e xilanase do fungo $H$. grisea ao longo de 120 ha presença de FT como única fonte de carbono. 34

Figura 17. Atividades de CMCase e xilanase do fungo $H$. grisea ao longo de $120 \mathrm{~h}$ na presença de glicose como única fonte de carbono .35

Figura 18. Avaliação das atividades de CMCase e xilanase do fungo $H$. grisea ao longo de $24 \mathrm{~h}$ na presença da droga 5-AZA e de BCA .36 
Figura 19. Atividade de CMCase do fungo $H$. grisea cultivado em $B C A$ e na presença de duas diferentes concentrações da droga 5-AZA por 2, 12 e 96 horas.

Figura 20. Atividade de CMCase do fungo $H$. grisea cultivado em Feno e na presença de duas diferentes concentrações da droga 5-AZA por 2, 12 e 96 horas. 38

Figura 21. Atividade de CMCase do fungo $H$. grisea cultivado em FT e na presença de duas diferentes concentrações da droga 5-AZA por 2, 12 e 96 horas. .38

Figura 22. Atividade de CMCase do fungo $H$. grisea cultivado em GLI e na presença de duas diferentes concentrações da droga 5-AZA por 2, 12 e 96 horas.

Figura 23. Atividade de xilanase do fungo $H$. grisea cultivado em $B C A$ e na presença de duas $\begin{array}{llllllllll}\text { diferentes concentrações da droga } & 5-A Z A & \text { por } & 2, & 12 & \text { e } & 96\end{array}$ horas...... 40

Figura 24. Atividade de xilanase do fungo $H$. grisea cultivado em feno moído e na presença de duas diferentes concentrações da droga 5-AZA por 2, 12 e 96 horas. .40

Figura 25. Atividade de xilanase do fungo $H$. grisea cultivado em FT e na presença de duas diferentes concentrações da droga 5-AZA por 2, 12 e 96 horas. .41

Figura 26. Atividade de xilanase do fungo $H$. grisea cultivado em glicose e na presença de duas diferentes concentrações da droga 5-AZA por 2,12 e 96 horas. 41

Figura 27. Quantificação das proteínas totais presentes nos sobrenadantes nas diferentes condições analisadas por RT-qPCR .42

Figura 28. Acúmulo de transcritos de mRNA do gene eg/1 do fungo $H$. grisea durante crescimento em diferentes substratos .44

Figura 29. Acúmulo de transcritos de mRNA do gene eg/4 do fungo $H$. grisea durante crescimento em diferentes substratos .45

Figura 30. Acúmulo de transcritos de mRNA do gene cbh1.1 do fungo $H$. grisea durante crescimento em diferentes substratos. 46

Figura 31. Acúmulo de transcritos de mRNA do gene $c b h 1.2$ do fungo $H$. grisea durante crescimento em diferentes substratos.

Figura 32. Acúmulo de transcritos de mRNA do gene $b g / 4$ do fungo $H$. grisea durante crescimento em diferentes substratos 48 
Figura 33. Acúmulo de transcritos de mRNA do gene xyn1do fungo $H$. grisea durante crescimento em diferentes substratos

Figura 34. Acúmulo de transcritos de mRNA do gene $x y n 2$ do fungo $H$. grisea durante crescimento em diferentes substratos. . .50

Figura 35. Correlação entre os valores de ensaios enzimáticos de CMCase com os de RTqPCR para o gene eg/1 .52

Figura 36. Correlação entre os valores de ensaios enzimáticos de CMCase com os de RTqPCR para o gene eg/4. .53

Figura 37. Correlação entre os valores de ensaios enzimáticos de CMCase com os de RTqPCR para o gene cbh1.2. .54

Figura 38. Correlação entre os valores de ensaios enzimáticos de xilanase com os de RTqPCR para o gene $x y n 1$ .56

Figura 39. Correlação entre os valores de ensaios enzimáticos de xilanase com os de RTqPCR para o gene $x y n 2$ .57 


\section{LISTA DE TABELAS}

Tabela 1: Quantidade total de resíduos agrícolas gerados nas culturas agrícolas brasileira no ano de 2009 . 14

Tabela 2: Lista de iniciadores de polimerização utilizados para RT-qPCR neste trabalho 


\section{LISTA DE ABREVIATURAS}

$\%:$ Por cento

${ }^{\circ} \mathrm{C}$ : Grau Celsius

1X: Concentração para uso

1000Xx: Mil vezes concentrado

2000X: Duas mil vezes concentrado

4mC: N4-metilcitosina

5mC: 5-metilcitosina

5-AZA: 5-aza-2'-desoxicitidina

6mA: N6-metiladenina

BCA: Bagaço de cana-de-açúcar

BMS: Ball-Milled Straw (Palha de cereal moída)

BSA: Albumina serica bovina

$\mathrm{C}_{6} \mathrm{H}_{8} \mathrm{O}_{7} \bullet \mathrm{H}_{2} \mathrm{O}$ : Ácido cítrico monohidratado

CBM: Módulo de ligação a carboidrato

cDNA: Sequência de DNA complementar

CMC: Carboximetil-celulose

CpG: Dinucleotídeo citosina-guanina

$\mathrm{CuSO}_{4} \bullet \mathrm{H}_{2} \mathrm{O}$ : Sulfato de cobre monohidratado

DNA: Ácido desoxirribonucleico

DNMTs: DNA metiltransferases

DNS: Ácido dinitrosalicílico

EDTA: Ácido etilenodiaminotetracetico

$\mathrm{Fe}\left(\mathrm{NH}_{4}\right)_{2}\left(\mathrm{SO}_{4) 2} \bullet 6 \mathrm{H}_{2} \mathrm{O}\right.$ : Sulfato de Ferro II e amônio hexahidratado

$\mathrm{FeSO}_{4}$ : Sulfato de ferro

FT: Farelo de trigo 


\section{GLI: Glicose}

H3K4me: Metilação no resíduo 4 de lisina da histona H3

H3K36me: Metilação no resíduo 36 de lisina da histona H3

H3K79me: Metilação no resíduo 79 de lisina da histona H3

H3K9: Resíduo 4 de lisina da histona H3

H3K27: Resíduo 27 de lisina da histona H3

H4K20: Resíduo 20 de lisina da histona H4

$\mathrm{H}_{3} \mathrm{BO}_{3}$ : Ácido bórico

H4K20: Metilação no resíduo 20 da histona H4

HDAC: Histona desacetilase

IPEA: Instituto de Pesquisa Econômica Aplicada

kb: Quilo pares de base

$\mathrm{KCl}$ : Cloreto de potássio

kDa: Quilo Dalton

Ki: Constante de dissociação

$\mathrm{KH}_{2} \mathrm{PO}_{4:}$ Fosfato monopotássico

MC: Meio completo

MeCP2: Methyl CpG binding protein 2

mg: Miligrama

$\mathrm{MgSO}_{4} \cdot 7 \mathrm{H}_{2} \mathrm{O}$ : Sulfato de magnésio heptahidratado

$\mathrm{mL}$ : Mililitro

mM: Milimolar

MM: Meio mínimo

$\mathrm{MnSO}_{4} \bullet \mathrm{H}_{2} \mathrm{O}$ : Sulfato de manganês monohidratado

$\mathrm{Na}_{2} \mathrm{MoO}_{4}-\mathrm{H}_{2} \mathrm{O}$ : Molibdato de sódio monohidratado

$\mathrm{NaNO}_{3}:$ Nitrato de sódio 
$\mathrm{NaOH}$ : Hidróxido de sódio

$\mathrm{pH}$ : Potencial hidrogenionico

q.s.p: Quantidade suficiente para

RIP: Repeat-induced point

RNA: Ácido ribonucleico

RNAi: RNA interferente

rpm: Rotações por minuto

RT-qPCR: Transcrição reversa - reação em cadeia da polimerase

SAM: S-adenosil-L-metionina

SDS-PAGE: Eletroforese em gel de poliacrilamida com dodecil sulfato de sódio

siRNA: pequenos RNAs interferentes

TBE: Tris-borato-EDTA

TE: Transposable element (Elemento transponível)

TSA: Tricostatina A

$\mathrm{UI} / \mathrm{mL}$ : Unidade internacional por mililitro

$\mu \mathrm{L}$ : Microlitro

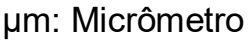

$\mu \mathrm{M}$ : Micromolar

$\mathrm{ZnSO}_{4}$ :Sulfato de zinco

$\mathrm{ZnSO}_{4} \bullet 7 \mathrm{H}_{2} \mathrm{O}$ : Sulfato de zinco heptahidratado 
INTRODUCÃO 


\subsection{INTRODUÇÃO}

Atualmente uma das áreas da biologia que mais tem se mostrado promissora e chamado a atenção dos pesquisadores é a epigenética. Este termo foi primeiramente utilizado em 1942 por Conrad H. Waddington (Waddington, 1942), um embriologista inglês que estudou a influência da genética no desenvolvimento embrionário, e desde a primeira vez que foi empregado muito foi acrescido à sua definição. Hoje podemos defini-la como o conjunto de alterações fenotípicas que não são meramente resultado da alteração na sequência de nucleotídeos do DNA e que são herdáveis tanto de uma célula a outra, via mitose, como de um organismo para sua prole por meio da meiose. A epigenética tem ajudado a entender fenômenos genéticos que antes não eram bem compreendidos, como por exemplo, 0 imprinting genômico (Kim et a.l, 2009), além disso tem colaborado no entendimento de componentes herdáveis que não podem ser explicados ou interpretados pela genética mendeliana clássica. Vários trabalhos têm relatado o envolvimento dos mecanismos epigenéticos em processos biológicos, dentre eles o desenvolvimento embrionário (Rose et al., 2014), diferenciação celular (Nair et al., 2014), plasticidade fenotípica (Champagne, 2013), resposta imune (Sinclair et al.,2014) e muitas doenças incluindo o câncer (Tam et al., 2013), a obesidade (Brenachot et al.,2014), as doenças autoimunes (Bjanesoy et al.,2014) e os transtornos mentais (revisto por Oh et al.,2014). Além disso, mecanismos epigenéticos já foram descritos em bactérias, archaea e eucariotos (Oliveiro and Katz, 2014) mostrando como eles foram conservados ao longo da evolução. Menos de 50 anos de estudos com epigenética já deixaram claro sua importância para os processos biológicos, porém muito ainda deve ser estudado nessa área que ainda está nos primeiros passos de uma longa caminhada.

\subsection{Mecanismos epigenéticos}

A epigenética parece estar relacionada sobretudo com a regulação da expressão gênica. O DNA é compactado dentro do núcleo celular por proteínas denominadas histonas e o conjunto formado pelo DNA mais histonas é chamado de cromatina. Na cromatina também existem proteínas acessórias que não são histonas e que também ajudam na compactação do DNA. O grau de compactação da cromatina dita se uma dada região gênica será transcrita ou não, caso esta cromatina esteja em um alto grau de compactação a transcrição gênica não ocorre, porém caso a cromatina esteja mais "frouxa" aquela região gênica pode ser acessada pela maquinaria de transcrição: RNA polimerase II e fatores de transcrição. A essas conformações da cromatina denominamos heterocromatina e eucromatina, respectivamente. Dessa forma, os mecanismos epigenéticos são diretamente relacionados com a forma como a cromatina se encontra, ditando o seu grau de compactação através de modificações químicas tanto no DNA quanto nas histonas. 


\section{Eucromatina}

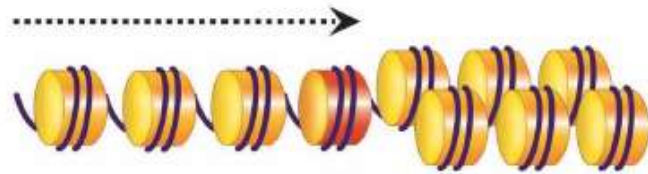

Heterocromatina

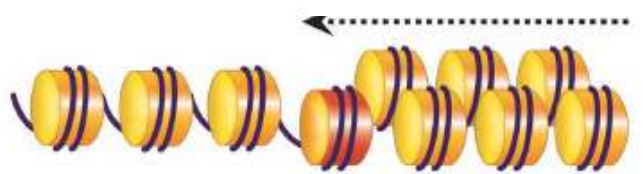

Figura 1. Representação esquemática ilustrativa das formas nas quais a cromatina pode ser encontrada. A eucromatina é menos compacta e permite ou facilita o acesso da maquinaria transcricional, já a heterecromatina é compactada e com isso é mais difícil o acesso desta maquinaria (Adaptado de Grewal and Elgin, 2007).

Os mecanismos epigenéticos mais estudados são a metilação do DNA e as modificações pós- traducionais de histonas, porém existem outros mecanismos descritos e sem dúvidas outros a serem descobertos. Um mecanismo que tem ganhado forte atenção nos últimos anos é o RNA interferente (RNAi), que envolve pequenos RNAs não-codificantes que têm a capacidade de regular a transcrição gênica em nível tanto transcricional como póstranscricional (revisto em Grewal and Elgin, 2007). As modificações pós-traducionais de histonas podem ser de vários tipos incluindo metilação, acetilação (particularmente de resíduos de lisina), fosforilação e ubiquitinação. Estas modificações acontecem nas caudas $\mathrm{N}$-terminais de histonas afetando quimicamente sua estrutura, tornando sua ligação com o DNA mais forte ou fraca e dessa forma deixando a cromatina mais relaxada ou mais compactada. Essas modificações das histonas podem tanto estarem associadas à repressão como a transcrição gênica, dependendo da modificação e do local em que ocorrem. Devido a essa complexidade é proposto um "código histônico" que tenta relacionar estas modificações ao estado transcrional da cromatina (Karch et al. 2013). As duas modificações mais estudadas são a acetilação e a metilação de histonas. A acetilação é associada à elevada atividade transcricional, uma vez que a adição de um grupo acetil em resíduos de lisina, geralmente da histona $\mathrm{H} 3$ e $\mathrm{H} 4$, diminui a interação entre a histona e o DNA tornando a cromatina mais relaxada. A metilação de histonas por outro lado exerce diferentes efeitos na cromatina, dessa maneira levando a diferentes efeitos na expressão gênica. A eucromatina (cromatina mais relaxada e transcricionalmente ativa) geralmente é rica em metilação na lisina 4 da histona $\mathrm{H} 3(\mathrm{H} 3 \mathrm{~K} 4 \mathrm{me})$, H3K36me e H3K79me, enquanto na heterocromatina (cromatina mais compactada e com baixa atividade transcricional) é comum ocorrer metilação nos resíduos de H3K9, H3K27 e H4K20. Além disso, grupos metil podem ser adicionados em três diferentes sítios de resíduos de lisina (mono-, di- ou trimetilação) e a dois diferentes sítios de resíduos de arginina (mono- ou dimetilação). A quantidade de grupos metil adicionados a estes resíduos têm impactos diferentes na estrutura da cromatina. Essas modificações químicas nas histonas são transmitidas durante a divisão celular e, como revisto por Motwani et al. (2012), modelos de 
herança epigenética baseados na conformação da cromatina propõem que nucleossomos portando modificações de histonas específicas são aleatoriamente distribuídos entre as cromátides irmãs durante a replicação do DNA. Nesses modelos, as próprias modificações específicas recrutam as enzimas responsáveis por modificar as histonas recém-sintetizadas que são incorporadas à cromatina logo após a replicação. Tais enzimas então modificam os novos nucleossomos e restauram a conformação original da cromatina, anterior à divisão celular. É impossível determinar qual mecanismo epigenético é mais importante, ainda mais que muitas vezes um depende de outro para acontecer, porém se pode dizer que a metilação do DNA é um dos mecanismos mais estudados e foco de muitos trabalhos hoje em dia.

\subsection{Metilação do DNA e a regulação gênica}

A metilação do DNA consiste na adição de um grupo metil (-CH3) no carbono na posição cinco do anel pirimídico de citosinas que geralmente se encontram seguidas por uma guanina, apesar de acontecer metilação em outros contextos. Esta adição de um radical metil dificulta ou impede o acesso da maquinaria transcricional levando a repressão gênica, além disso, DNA metilado pode ser reconhecido por complexos enzimáticos, como MeCP2, que podem levar ao silenciamento gênico (Ho et al.,2008). A metilação de citosinas que são seguidas de guaninas é muito comum em células de mamíferos, esse dinucleotídeo pode ser encontrado em clusters localizados geralmente próximos à região promotora de genes, nesse contexto denominados como ilhas CpG (revisto em Hernando-Herraez et al.,2015). Já em plantas é muito comum acontecer metilação em citosinas que não estão nesses aglomerados, sendo frequente em $\mathrm{CHG}$ e $\mathrm{CHH}(\mathrm{H}=\mathrm{A}, \mathrm{C}$ ou $\mathrm{T})$, mas também ocorrendo em $\mathrm{CG}$ (revisto em Xin-Jian $\mathrm{He}$ et al., 2011). Isso demonstra que apesar de ocorrer em diferentes contextos e em diferentes grupos de seres vivos a metilação de citosinas, gerando o nucleotídeo $5 \mathrm{mC}$, foi conservada ao longo da evolução. Além deste nucleotídeo, estudos recentes têm relatado a existência de N6-metiladenina $(6 \mathrm{~mA})$ e N4-metilcitosina $(4 \mathrm{mC})$, porém essas duas modificações são exclusivas de procariotos e de certos grupos de eucariotos, como C.elegans (Greer et al., 2015) e Drosophila (Zhang et al., 2015).

A metilação do DNA é catalisada pelas enzimas da família das DNA metiltransferase (DNMTs), que podem realizar a metilação de novo (metilação em sítios que não eram metilados anteriormente) e de manutenção. Essas enzimas transferem um grupo metil de um doador universal, a S-adenosil-L-metionina (SAM), para resíduos de citosina presentes no DNA (Jin and Robertson, 2013). Já foram descritas cinco DNMTs em mamíferos: DNMT1, DNMT2, DNMT3A, DNMT3B e DNMT3L, cada uma com uma função específica e atuando em um determinado processo biológico (Golbabapour et al.,2011). As enzimas DNMT3 são responsáveis pela metilação de novo atuando principalmente na embriogênese gerando os primeiros padrões de metilação que são mantidos pela DNMT1, a DNMT de manutenção. Diferente das DNMT3, a DNMT1 tem preferência por sítios hemimetilados (metilação em apenas uma das fitas de DNA) e é capaz de metilar a outra fita do DNA replicando desta maneira o padrão de metilação existente na fita molde, por isso é denominada como DNMT de 
manutenção. Pouco se sabe ainda sobre a DNMT2, porém já foi demonstrado que é capaz tanto de metilar DNA como RNA (revisto em Maresca et al.,2015).

Assim como as modificações pós-traducionais de histonas, a metilação do DNA é transmitida durante a replicação do DNA, sendo a hereditariedade uma característica obrigatória para que um processo possa ser considerado herança epigenética e não apenas um mecanismo transitório. No caso da transmissão dos padrões de metilação, como mencionado anteriormente, a enzima DNMT1 é o principal atuante, detectando sítios hemimetilados na fita molde e reproduzindo esses padrões na fita recém sintetizada. $A$ replicação do DNA é um processo semiconversativo, no qual a partir de uma fita molde, a DNA polimerase e outras enzimas acessórias são capazes de gerar uma nova fita, porém esta enzima não é capaz de metilar as citosinas na nova fita de DNA e é nesse momento que a DNMT1 entra em ação. A fita molde ainda possui citosinas metiladas e esses sítios são detectados pela DNMT1, que irá metilar na nova fita o resíduo de citosina que esteja na mesma posição, mantendo dessa forma o padrão de metilação ao longo das divisões celulares.

\section{N-terminal domínio regulatório C-terminal domínio catalítico}
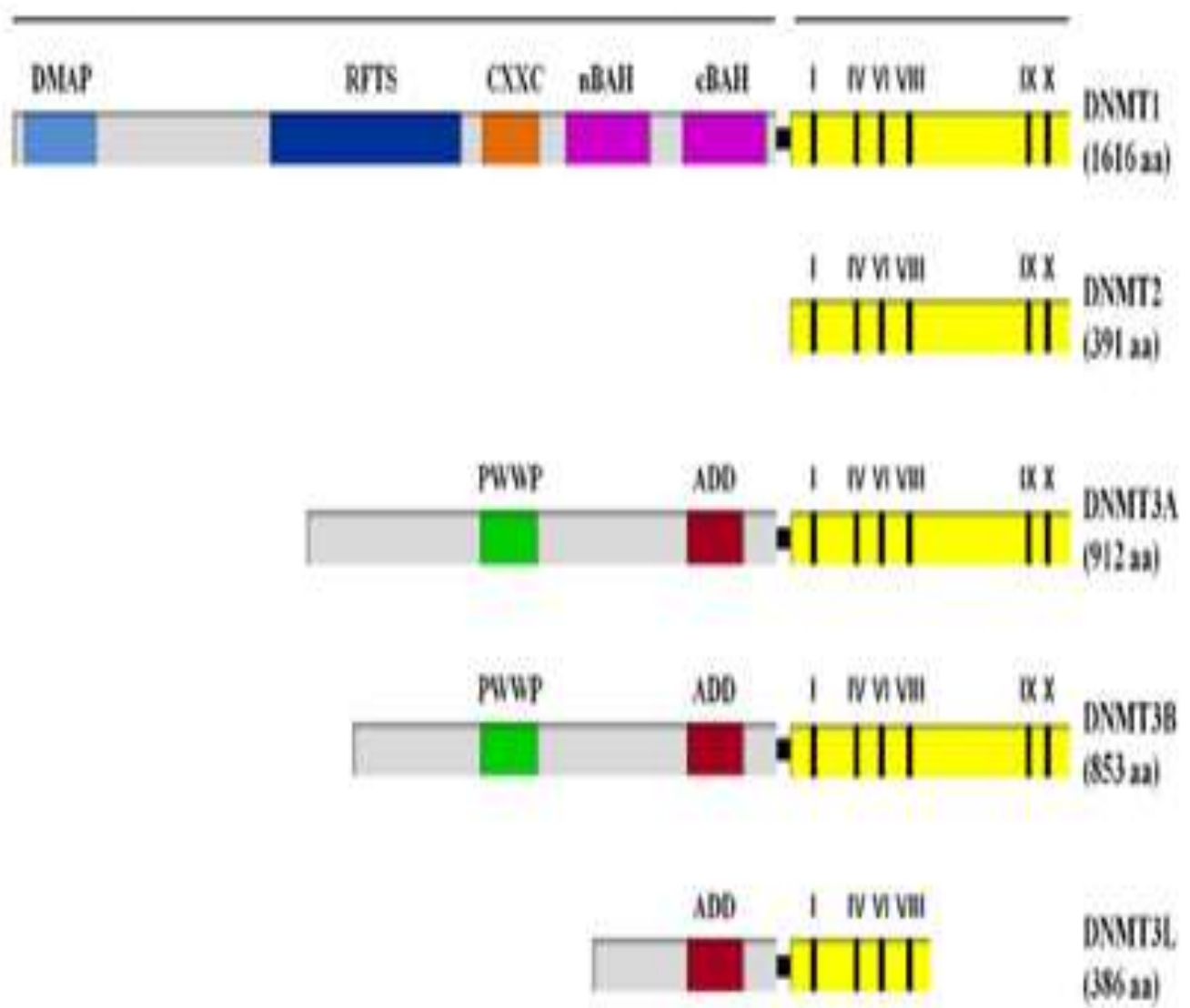

DNMIIS. (3⿻日木)

Figura 2. Representação estrutural das cinco DNMTs já descritas, mostrando o número de resíduos de aminoácidos de cada uma e seus domínios de ligação (Adaptado de Maresca et al, 2015) 
Apesar do crescente interesse na epigenética, muitos pesquisadores focam em trabalhos com mamíferos, plantas e insetos fazendo com que os estudos com outros modelos, como fungos, ainda sejam muito limitados e concentrados em organismos modelos (revisto em Brosch et al., 2008).

\subsection{Epigenética em fungos}

Os principais modelos de estudo de epigenética em fungos são Schizosaccharomyces pombe, Neurospora crassa, e Saccharomyces cerevisiae, sendo pouco estudado em outros organismos. Mesmo assim, a epigenética parece ser de crucial importância em processos biológicos relacionados com estes modelos, não descartando sua relevância em outros fungos. Em S. pombe diversos artigos têm relatado a importância dos pequenos RNAs interferentes (do inglês siRNAs) agindo conjuntamente com a metilação de histonas no processo de formação da heterocromatina (Yu et al.,2014; Kuscu et al.,2014 ). Em N. crassa sabe-se que a metilação do DNA ocorre principalmente dentro de relíquias de transposons e regiões repetitivas de DNA ribossomal, mas Dang et al (2013) elucidaram um mecanismo de transcrição convergente que induz metilação dinâmica do DNA em regiões gênicas diferentes e com função ainda não conhecida. Abraham et al. (2012) alegam terem fornecido a base para o desenvolvimento da "epigenética de populações" com seus estudos em S. cerevisiae. Quando a droga Tricostatina A (TSA), inibidora de enzimas histona desacetilases (HDACs) foi colocada em contato com a levedura, os autores observaram que alguns epipolimorfismos encontrados entre duas linhagens selvagens distintas de leveduras são temporários, enquanto outros são persistentes, podendo essa persistência ser explicada em parte por determinantes genéticos convencionais, codificados no DNA. Lee et al (2008) clonaram e caracterizaram o gene da DNA metiltransferase $A(d m t A)$, um homólogo da DNMT de Aspergillus nidulans, um fungo que é conhecido por não apresentar metilação no DNA. Eles verificaram que esta enzima, apesar de ser restrita a algumas células, é essencial para o ciclo de reprodução sexual do fungo. Trabalhos também já foram realizados com fungos fitopatogênicos, Izawa et al (2009) verificaram que o uso do modulador epigenético, TSA, em Magnaporthe oryzae diminuiu a formação do apressório uma estrutura importante para o fungo infectar a planta, dessa forma diminuindo sua patogenicidade. Van West et al.( 2008 ) trabalhando com 3 moduladores epigenéticos, a TSA, o butirato de sódio e a 5-azacitidina, afirmam terem encontrado evidências para remodelagem da cromatina e a desacetilação de histonas controlarem a expressão gênica em Phytophthora infestans. Esses são alguns exemplos de trabalhos envolvendo epigenética em fungos, sendo muito comum o uso de moduladores epigenéticos e avaliação de seu efeito em um determinado processo biológico. Esses moduladores são drogas com a função de inibir a atividade de enzimas relacionadas com modificações epigenéticas, como as DNA metiltransferases ou histona desacetilases, e dessa forma alterar a estrutura da cromatina. Em uma revisão, Strauss \& Reyes-Dominguez (2011), comentam sobre a importância da estrutura da cromatina na regulação da expressão de genes relacionados 
com a produção de metabólitos secundários, como micotoxinas e antibióticos, em fungos ascomicetos e basidiomicetos.

\subsection{Metilação do DNA em fungos}

A metilação do DNA é um importante mecanismo epigenético e amplamente estudado em diversos grupos de organismos, contudo a sua ocorrência evolutiva ainda é controversa uma vez que algumas espécies carecem de enzimas envolvidas neste processo ou de níveis significativos de $5 \mathrm{mC}$. Em plantas e mamíferos este mecanismo é essencial para o desenvolvimento normal do indivíduo (revisto em Xin-Jian He et al.,2011), mas em fungos sua importância ainda é incerta, uma vez que ocorre em espécies como $N$. crassa, mas é ausente, ou muito escassa, em leveduras como S.cerevisiae e S.pombe (revisto em Aghcheh et al., 2015)

N.crassa é uma verdadeira enciclopédia para estudos epigenéticos em virtude de este organismo apresentar metilação de DNA, modificações pós-traducionais de histonas e RNAi funcionais e agindo sinergisticamente em processos regulatórios (revisto em Aramayo and Selker,2013). Selker et al. (2003) demonstraram que a metilação do DNA nesta espécie de fungo filamentoso ocorre quase exclusivamente em relíquias de transposons que sofreram mutação através de um sistema de defesa do genoma denominado RIP (repeat-induced point) mutation. Este mecanismo é bastante estudado, principalmente por envolver tanto metilação do DNA como de histona, direcionando a formação de heterocromatina (figura 3). A histona H3 na região de uma relíquia de RIP é metilada em seu resíduo 9 pela ação de uma histona metilase (DIM-5) e esta marca (H3K9me) é reconhecida pela HP1(Heterochromatin Protein-1) que por sua vez recruta a DNA metiltransferase DIM-2 levando a formação da heterocromatina nessa região gênica (Lewis et al., 2009).
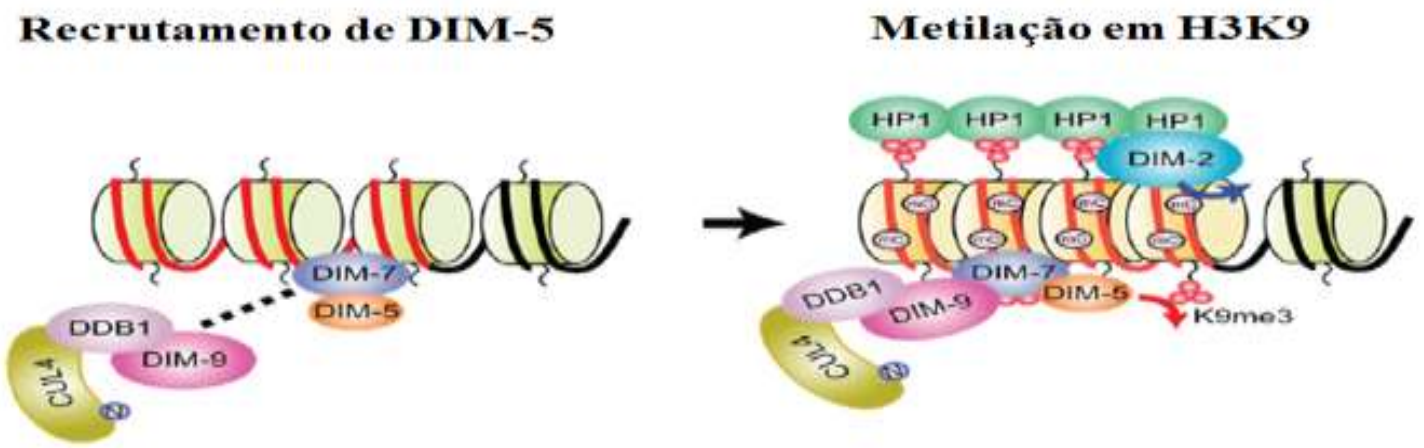

Figura 3. Esquema ilustrativo mostrando a formação da heterocromatina em regiões de relíquias de RIPs em N.crassa. DIM-5 é uma histona metilase que adiciona grupos metil na lisina 9 da histona $\mathrm{H} 3$, sendo esta marca (H3K9me) reconhecida pela HP1, que por sua vez recruta a DIM-2, a DNA metiltransferase dessa espécie. Esse sinergismo entre metilação de 
histona e DNA leva a formação da heterocromatina nessa região gênica (Adaptado de Lewis et al., 2010)

Chen et al. (2014) realizando análises de metiloma e transcriptoma do fungo Tuber melanosporum (conhecido gastronomicamente como "Trufa negra") revelaram uma elevada taxa de metilação de citosina ( $>44 \%$ ) no genoma desse fungo, ocorrendo preferencialmente em elementos transponíveis (TE). Além disso, o tratamento com 5-azacitidina, um inibidor da ação de DNA metiltransferases, reduziu parcialmente os níveis de metilação e aumentou a transcrição de TEs. Esses dados corroboram a hipótese da metilação do DNA funcionar como um mecanismo de silenciamento de TEs, assim como em N.crassa.

Ikeda et al.(2013) trabalhando com diferentes isolados de Magnaporthe (56 de M.oryzae, 3 de M.grisea e 1 de Magnaporthe sp.) avaliaram a metilação de um retrotransposon , MAGGY( Magnaporthe gypsy-like elemente) e descobriram um perfil de metilação diferencial nestes isolados. Dos 60 isolados, 42 apresentaram metilação nesse elemento enquanto os outros 18 não. O gene MoDMT1, que codifica uma DIM-2 like DNMT, é o responsável pela metilação do DNA nesta espécie de fungo, porém quando a sequência deste gene foi analisada nos diferentes isolados foram encontrados pontos de mutação, sugerindo que este perfil diferencial de metilação pode ser fruto de mutações sofridas neste locus.

Todos os exemplos citados anteriormente estão relacionados com silenciamento de TEs. De fato, é consenso na literatura que a metilação de DNA em fungos funciona como um mecanismo de defesa contra transposição de TEs (revisto em Zemach and Zilberman, 2010), com alguns trabalhos relatando o efeito da metilação de DNA na regulação de metabólicos secundários (Zutz et al., 2013). Nenhum trabalho avaliando o efeito da metilação do DNA em H. grisea foi realizado até o momento.

\subsection{5-aza-2'-desoxi-citidina}

A 5-aza-2'-desoxi-citidina (5-AZA) é um análogo do nucleosídeo citidina capaz de inibir a atividade de enzimas DNA metiltransferases (DNMTs, EC2.1.1.37) (Jones \& Taylor, 1980). O mecanismo de ação da 5-AZA baseia-se em sua incorporação à molécula de DNA: por possuir um átomo de nitrogênio na posição cinco do anel pirimídico, a transferência do grupo metil não ocorre e a enzima permanece ligada covalentemente à fita de DNA (Figura 4). Assim, as DNMTs não são capazes de transferir grupos metil para as citosinas das fitas de DNA hemimetiladas geradas após a replicação, o que provoca a hipometilação passiva da molécula (Stresemann and Lyko, 2008). Isso leva a reativação de genes previamente silenciados pela hipermetilação de suas regiões regulatórias (Burgers et al., 2002). Em altas concentrações é citotóxica por causar extensivo dano ao DNA (Eglen \& Reisine, 2011). Em uma revisão, Karahoca and Momparler (2013) comentam sobre a aplicabilidade da 5-AZA em tratamentos de 
doenças como a síndrome mielodisplásica, leucemia e até em tumores sólidos, nas quais o tratamento com a droga parece ativar genes com metilação aberrante de DNA.

Um detalhe importante que se deve levar em conta ao trabalhar com esta droga é sua instabilidade em meio aquoso. Alguns trabalhos relatam sua decomposição em temperatura fisiológica e em $\mathrm{pH}$ neutro, com a liberação de uma variedade de produtos de degradação que podem afetar as análises propostas e a reprodutividade dos experimentos, além disso ainda não há um consenso sobre sua meia-vida nessas condições, podendo variar de 3 a 21 horas dependendo do método utilizado para avaliação (Rogstad et al. ,2009 ; Z. Liu et al., 2006). O ideal é padronizar a concentração, a temperatura e o tempo de incubação com a droga nas condições do experimento, lembrando que o aumento de temperatura e a alteração do pH , tanto para ácido como para básico, afetam a estabilidade da droga.
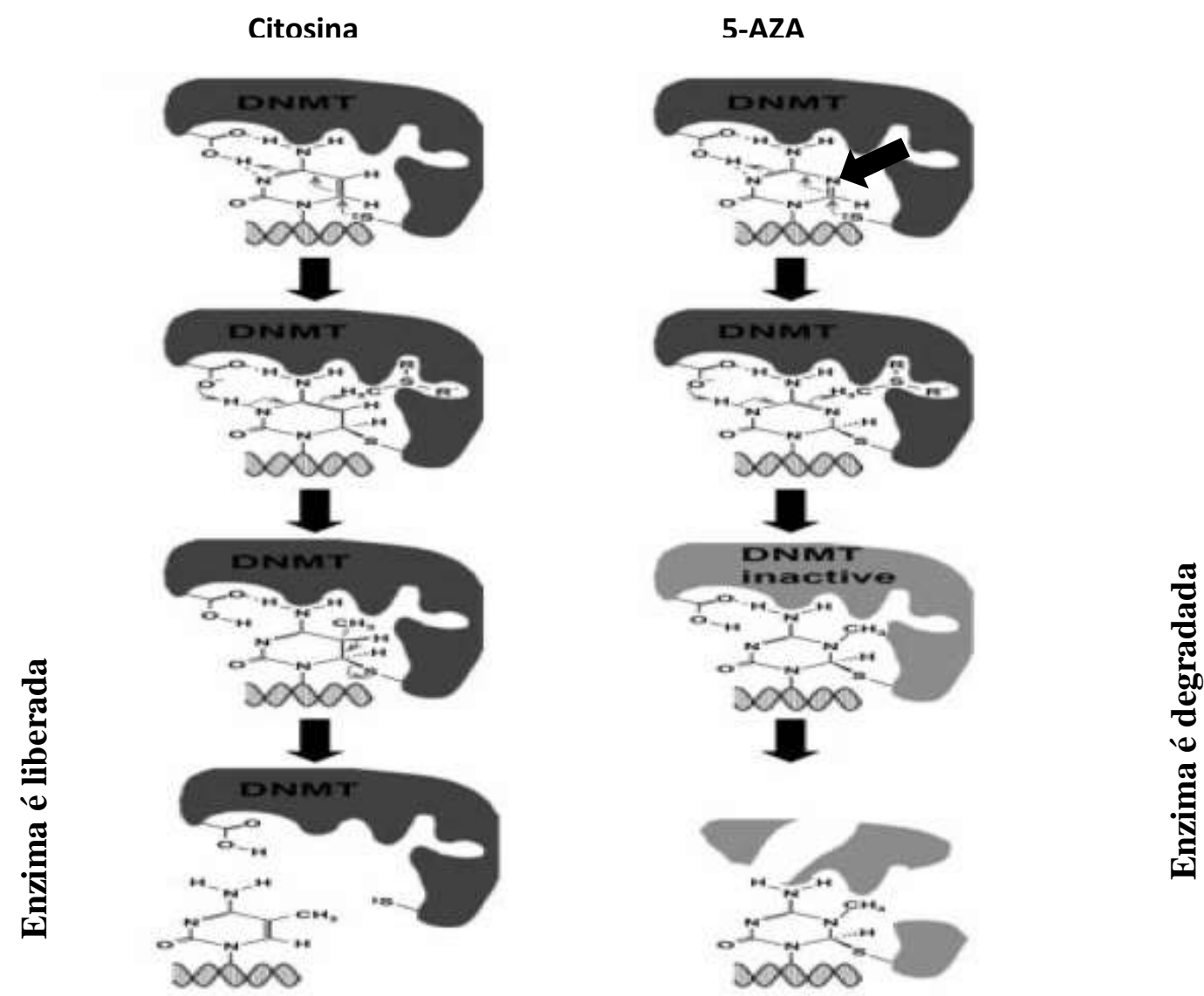

Figura 4. Representação esquemática do mecanismo de ação da 5-AZA. A seta preta indica o átomo de nitrogênio na posição 5 do anel pirimídico na 5-AZA, o que faz com que a enzima DNMT ao se ligar a essa molécula não consiga se dissociar, permanecendo covalente ligada à fita de DNA. A enzima torna-se inativa e posteriormente é degrada, levando a um estado hipometilado depois da replicação do DNA (Adaptado de Stresemann and Lyko, 2008). 
Há poucos estudos na literatura utilizando esta droga em fungos filamentosos produtores de enzimas celulolíticas, apesar de existir trabalhos que utilizam seu análogo, a 5azacitidina, avaliando o seu efeito no metaboloma secundário de fungos (Williams et al., 2008). Com isso, a utilização deste modulador epigenético em fungos como $H$. grisea, que são capazes de degradar a complexa parede celular vegetal, é uma área a ser explorada.

\subsection{O desafio da parede celular vegetal}

A biomassa vegetal é o recurso energético mais abundante no planeta, mas para acessá-lo é necessário superar a complexidade da parede celular vegetal, liberando os monômeros de sacarídeos que constituem sua estrutura. Ela é composta majoritariamente por celulose, hemicelulose e lignina, podendo ainda apresentar pectina em sua estrutura, um complexo polifenólico hidrofóbico que dificulta ainda mais a degradação desta biomassa (revisto por Mottiar et al, 2016). Alguns microrganismos são capazes de vencer essa complexidade estrutural e degradar a parede celular através da secreção de enzimas como celulases, hemicelulases, pectinases e ligninases (revisto, por exemplo, por Crucello et al., 2015). O aumento da expressão e secreção destas enzimas em microrganismos capazes de produzi-las tem sido o foco de diversos trabalhos científicos, uma vez que elas são essenciais para o tratamento da biomassa vegetal oriunda de resíduos agrícolas e que pode ser utilizada para produção de diversos subprodutos, incluindo o etanol de $2^{\circ}$ geração (Kang et al., 2014; Okamoto et al., 2014).

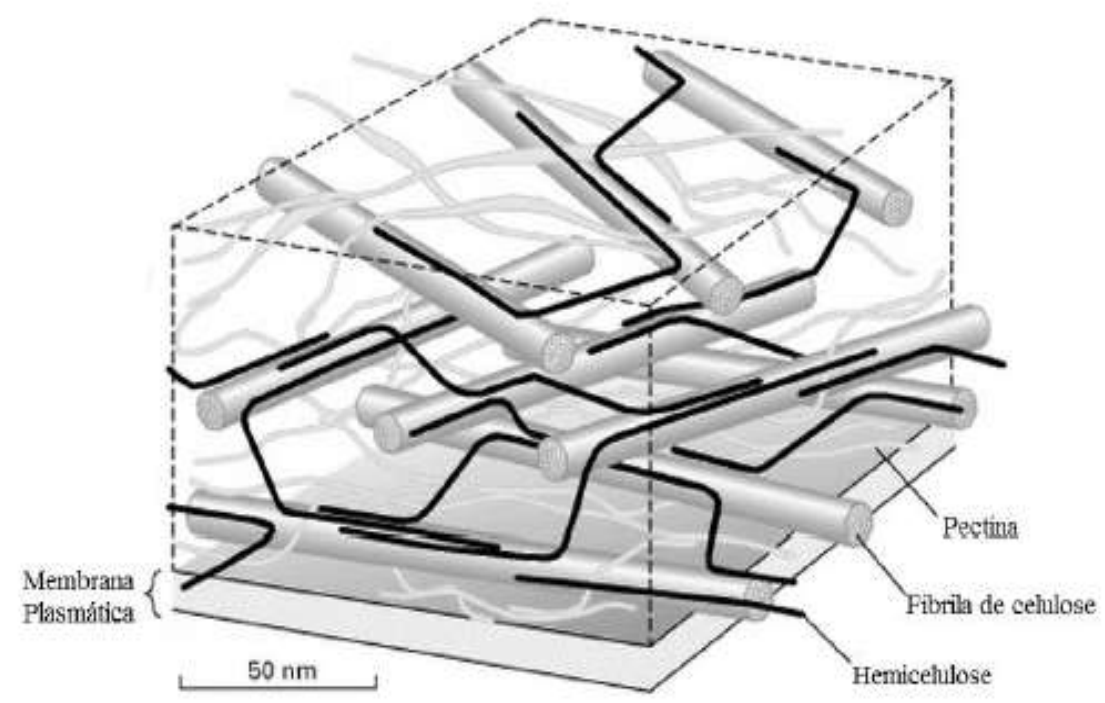

Figura 5. Representação esquemática da estrutura da parede celular vegetal, mostrando seus três componentes básicos celulose, hemicelulose e pectina, podendo ainda conter lignina, dificultando ainda mais a sua degradação (Adaptado de Lodish et al., 2000) 
A celulose é o principal constituinte da biomassa vegetal, sendo composta por longos polímeros lineares de D-glicose unidos por ligações $\beta$-1,4. Esta organização linear é basicamente simples, o que torna a celulose tão difícil de ser degradada é sua estrutura física (Béguin \& Aubert, 1994). A complexidade deve-se as cadeias paralelas agrupadas por meio de numerosas ligações de hidrogênio e forças de van der Waals, formando microfibrilas rígidas e insolúveis, que por sua vez se reúnem em fibras de alto grau de cristalinidade, entremeadas por regiões amorfas. Para que essa estrutura complexa seja desfeita e os monômeros de glicose se tornem disponíveis, três famílias de enzimas atuam de forma sinergística (figura 6): as endoglicanases (EC 3.2.1.4), as exoglicanases (EC 3.2.1.91) e as $\beta$-glicosidases (EC 3.2.1.21). As endoglicanases clivam as ligações $\beta-1,4$ ao longo da cadeia de celulose, preferencialmente em regiões amorfas da fibra de celulose. As exoglicanases, também conhecidas como celobiohidrolases, atuam liberando a celobiose (um dímero de glicose) das extremidades redutoras e não-redutoras, particularmente na região cristalina da celulose. Por fim, as $\beta$-glicosidases têm como função liberar a glicose das pequenas cadeias de oligossacarídeos a partir de resíduos de celobiose (revisto em Aro et al., 2005).

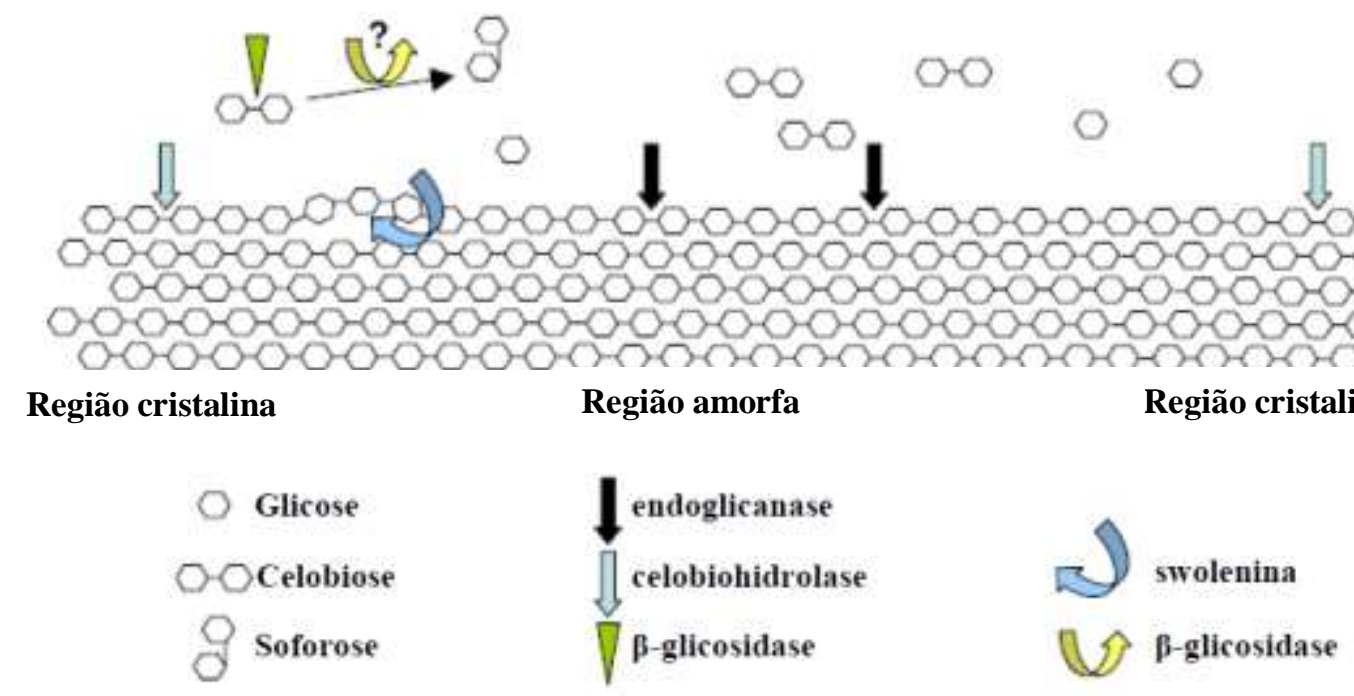

Figura 6. Representação esquemática da estrutura da celulose e enzimas responsáveis por sua degradação. As endoglicanases clivam as ligações beta-1,4 ao longo da cadeia de celulose, preferencialmente em regiões amorfas, as celobiohidrolases, atuam liberando celobiose (um dímero de glicose) das regiões cristalinas e as beta-glicosidases liberam a glicose das pequenas cadeias de oligossacarídeos a partir de resíduos de celobiose e celodextrina (Adaptado de Arol et al., 2005)

A lignina é o componente menos abundante dos resíduos vegetais, porém o mais recalcitrante de todos. Ela é formada por uma estrutura molecular complexa (figura 8) contendo polímeros ramificados de monômeros fenólicos, principalmente os álcoois $p$-coumaril, coniferil e sinapil, funcionando como uma barreira física contra microrganismos patogênicos, no entanto, preservando a permeabilidade da planta a água (Lee et al. 2014). Sua presença na biomassa 
vegetal dificulta a ação das enzimas celulolíticas, como as celulases e xilanases. A degradação da lignina ocorre através da ação de enzimas denominadas ligninases que podem ser de duas famílias: fenol oxidases (laccase) ou peroxidases (lignina peroxidase e manganês peroxidase) (Dashtban et al.2009).

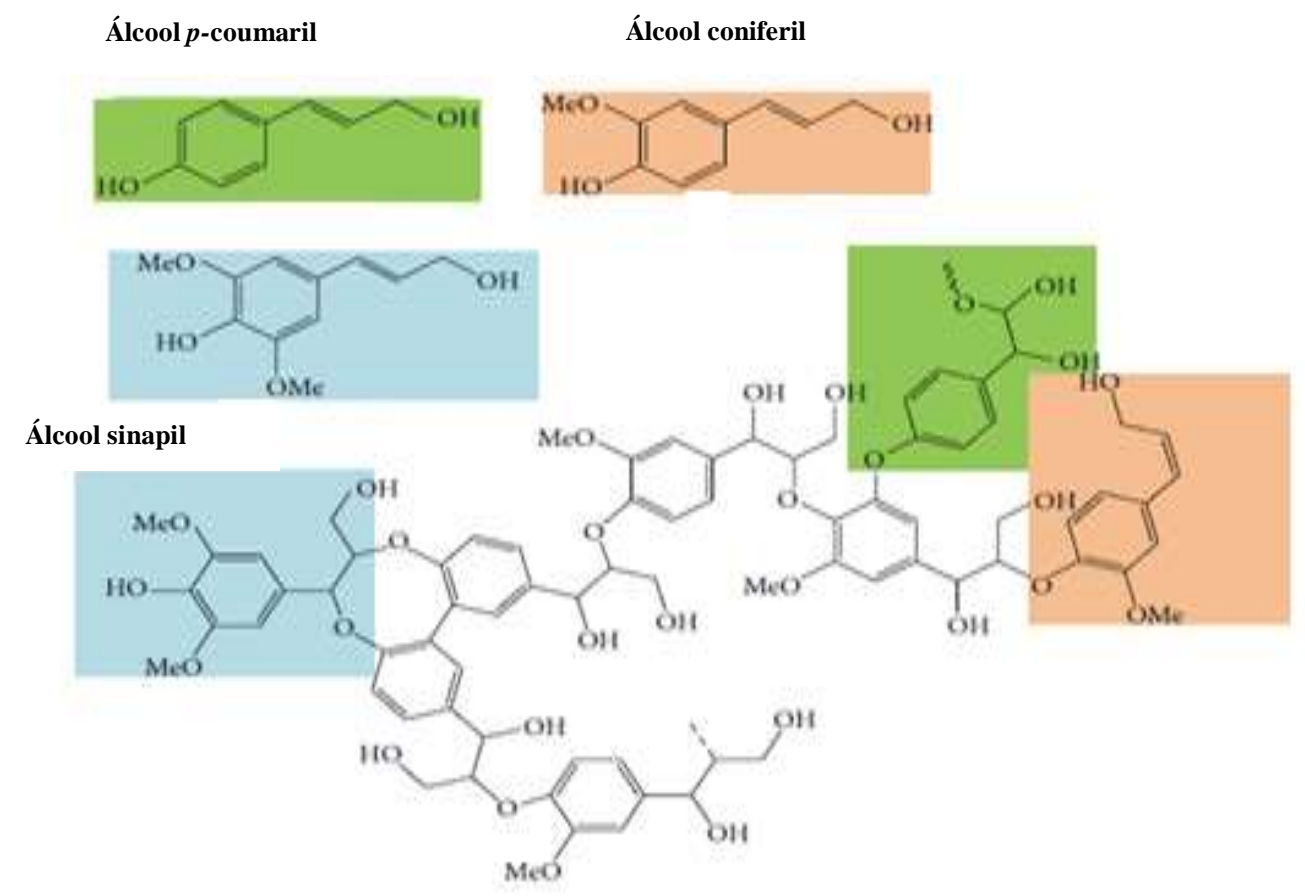

Figura 7. Representação da estrutura química da lignina mostrando os monômeros fenólicos que a compõem, os álcoois p-coumaril, coniferil e sinapil,( Adaptado de Lee et al, 2014)

A hemicelulose está presente na parede celular e na lamela média de células vegetais e é o segundo composto mais abundante na biomassa vegetal. É formada principalmente por xilana, podendo também ser formada por mananas, glicanas, arabinanas e galactanas, dependendo das unidades monossacarídicas que compõem sua estrutura (Cosgrove et al. 2005). A xilana é um heteropolímero ramificado formado por unidades de Dxiloses interligadas por ligações glicosídicas beta-1,4 e com ramificações de resíduos de arabinofuranose, ácido glucurônico e ácido metilgalacturônico. As endoxilanases (EC 3.2.1.8) são as enzimas responsáveis pela degradação da xilana, clivando as ligações internas $\beta-1,4 \mathrm{e}$ gerando xilooligosacarídeos que são degradados a resíduos de xilose pelas $\beta$-D-xilosidases (EC 3.2.1.37) (Polizeli et al. 2005). 


\section{(a)}

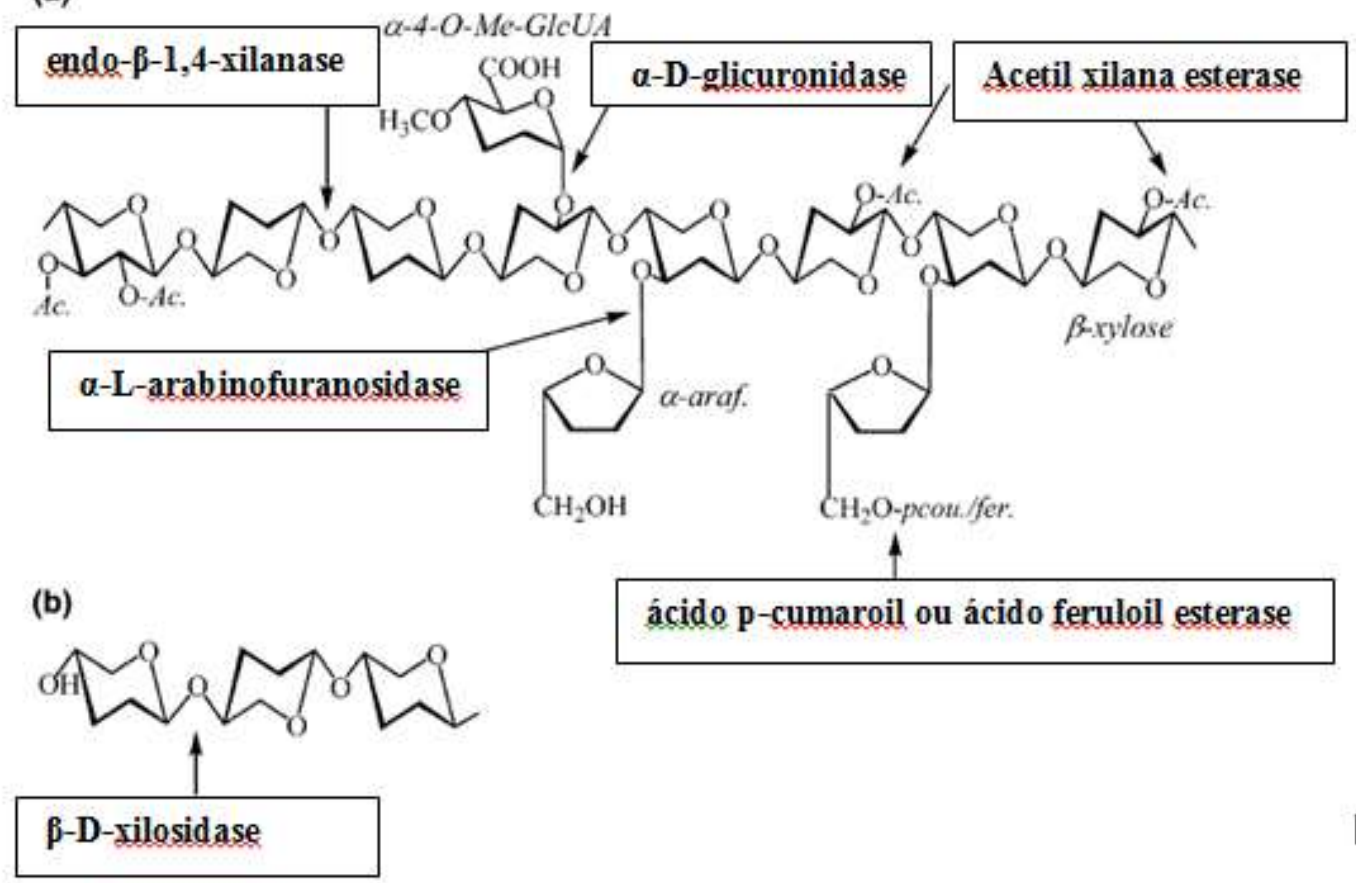

Figura 8. Representação da Estrutura da xilana e enzimas que atuam em sua degradação. Em (a) os sítios de ação de cada enzima e em (b) a hidrólise de xilooligosacarídeos pela ação da $\beta$-D-Xilosidase. Os monômeros que compõe a estrutura da xilana representada são resíduos de xilose $\beta-1,4$ ligados. Ac: grupo acetil ; $\alpha$-araf: $\alpha$-arabinose ; pcoum: ácido $p$-cumárico e fer: ácido ferúlico( Adaptado de T. Collins et al., 2005)

Como notado, é um desafio para qualquer organismo superar este complexo de polissacarídeos diferentes e conseguir utilizar os monossacarídeos básicos presentes. De fato, é necessário um arsenal de enzimas lignoceluloliticas, cada uma com sua função e alvos específicos, agindo sinergisticamente para degradar a celulose, hemicelulose e a lignina. Esta complexidade estrutural também torna difícil a reciclagem de resíduos agrícolas, gerando anualmente bilhões de toneladas de biomassa vegetal não aproveitada. $O$ reaproveitamento desses resíduos pode ser possível utilizando microrganismos produtores destas enzimas, que além de ajudarem na degradação da biomassa residual podem também gerar produtos com alto valor agregado, como o xilitol (Tamburini et al., 2015). Espécies dos gêneros Trichoderma, Penicillium, Schizophyllum, Aspergillus e Humicola são exemplos de fungos produtores de enzimas celulolíticas.

\subsection{Fungos e sua importância industrial}

Seja para produção de bebidas alcoólicas, como vinhos e cervejas, ou para produção de alimento, como pão e massas, os fungos sempre tiveram seu valor para o ser humano. Hoje 
estes microrganismos, ou as enzimas produzidas por estes, são utilizados em diversos processos industriais que vão além da produção de bebidas e alimentos. Processamento e preservação de alimentos, obtenção de inoculantes agrícolas de nova geração (como micorrizas, endofíticos e agentes de controle biológico), produção de drogas redutoras do colesterol, imunossupressoras e antitumorais (respectivamente: estatinas, ciclosporinas e taxol), produção de antibióticos e produção de coquetéis enzimáticos são alguns exemplos da utilização destes organismos (Lange et al. 2012). Fungos produtores de enzimas lignocelulolíticas podem ser utilizados para degradação de resíduos agrícolas, como o bagaço da cana-de-açúcar, maximizando o aproveitamento desta biomassa vegetal residual (De-Paula et al., 1999).

Com o aumento da demanda energética e a procura por novas fontes alternativas sustentáveis, fungos lignocelulolíticos podem representar a solução tão almejada. Segundo relatório do IPEA 2012 (Instituto de Pesquisa Econômica Aplicada), em 2009 foram geradas no Brasil mais de 290 milhões de toneladas de resíduos agrícolas, sendo 200 milhões de toneladas apenas de cana-de-açúcar (tabela 1).

O Brasil é o maior produtor de cana-de-açúcar no mundo e a grande quantidade de biomassa residual gerada é resultado de sua utilização para obtenção de bioetanol de $1^{\circ}$ geração (Abreu et al., 2011). Essa por sua vez é uma fonte energética limpa e renovável, porém que gera grandes quantidades de resíduos vegetais, muitas vezes não aproveitados. Após a extração do caldo da cana-de-açúcar o que sobra é o bagaço, formado basicamente por parede celular vegetal, mas que ainda possui grande matéria-prima energética. Com o auxílio de microrganismos lignocelulolíticos, do tratamento físico/químico adequado e de processos fermentativos, é possível utilizar essa biomassa para geração de mais bioetanol, o denominado etanol de $2^{\circ}$ geração (Pothiraj et al., 2006). Por ser uma alternativa viável ao aumento da demanda energética mundial, esforços têm sido empregados para o

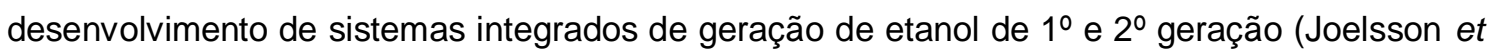
al., 2016). 


\begin{tabular}{|c|c|c|c|c|c|c|c|}
\hline \multirow{2}{*}{$\begin{array}{c}\text { Produto/fase } \\
\text { Culturas }\end{array}$} & \multicolumn{3}{|c|}{ Produção total } & \multirow{2}{*}{$\begin{array}{c}\text { Residuos } \\
\text { (\%) }\end{array}$} & \multirow{2}{*}{$\begin{array}{c}\text { Total de } \\
\text { residuos } \\
\text { (t/ano) }\end{array}$} & \multirow{2}{*}{$\begin{array}{l}\text { Efluentes } \\
\left.\text { ( } \mathrm{m}^{3} / \mathrm{ano}\right)\end{array}$} & \multirow{2}{*}{$\begin{array}{l}\text { Potencial } \\
\text { energético } \\
\text { (MW/ano) }\end{array}$} \\
\hline & Produção (t) & $\begin{array}{l}\text { Consumo in } \\
\text { natura (t) }\end{array}$ & $\begin{array}{l}\text { Industrializa- } \\
\text { çấ (t) }\end{array}$ & & & & \\
\hline Soja & 57.345 .382 & - & 57.345 .382 & 73 & 41.862 .129 & - & 3.422 \\
\hline Milho & 50.745 .996 & - & 50.745 .996 & 58 & 29.432 .678 & - & 2.406 \\
\hline $\begin{array}{l}\text { Cana-de-açú- } \\
\text { car (bagaço e } \\
\text { torta de filtro) }\end{array}$ & 671.394 .957 & - & 671.394 .957 & 30 & 201.418.487 & - & 16.464 \\
\hline $\begin{array}{l}\text { Cana-de-açú- } \\
\text { car (vinhaça) }\end{array}$ & & & & - & - & 604.255 .461 & - \\
\hline Feijâo & 3.486 .763 & - & 3.486 .763 & 53 & 1.847 .984 & - & 143 \\
\hline Arroz & 12.651 .774 & - & 12.651 .774 & 20 & 2.530 .355 & - & 175 \\
\hline Trigo & 5.055 .525 & - & 5.055 .525 & 60 & 3.033 .315 & - & 238 \\
\hline Mandioca & 23.786 .281 & - & - & - & - & - & - \\
\hline Café & 2.440 .057 & - & 2.440 .057 & 50 & 1.220 .029 & - & 97 \\
\hline Cacau & 218.487 & - & 218.487 & 38 & 83.025 & - & 7 \\
\hline Banana & 6.642 .739 & 6.443 .457 & 199.282 & 50 & 99.640 & - & - \\
\hline Laranja & 18.385 .991 & 735.440 & 17.650 .551 & 50 & 8.825 .276 & - & - \\
\hline Coco-da-baía & 964.303 & 289.291 & 675.012 & 60 & 405.009 & - & 39 \\
\hline $\begin{array}{l}\text { Castanha-de- } \\
\text { caju }\end{array}$ & 220.505 & 110.253 & 110.253 & 73 & 80.484 & - & 8 \\
\hline Uva & 1.365 .720 & 751.146 & 614.574 & 40 & 300.459 & - & - \\
\hline Total & 854.704 .480 & 8.329 .587 & 822.588 .613 & - & 291.138 .870 & 604.255 .461 & 22.999 \\
\hline
\end{tabular}

Tabela 1. Quantidade total de resíduos agrícolas gerados nas culturas agrícolas brasileiras no ano de 2009 (Fonte IPEA, 2012)

Algumas espécies de fungos são capazes de hidrolisar a xilana, principal constituinte da hemicelulose, e catabolizar os monossacarídeos de D-xilose para gerar etanol, sendo altamente atrativas para utilização na produção de bioetanol (Okamoto et al. 2014). Porém, a taxa de conversão de biomassa em etanol é muito baixa nestes organismos, necessitando de mais estudos para potencializar este processo. Esforços são despendidos para melhorar geneticamente microrganismos capazes de degradar a celulose/hemicelulose e utilizarem os açúcares liberados para gerar etanol, maximizando o aproveitamento dos resíduos agrícolas (revisto por Kricka et al. 2014).

As xilanases são enzimas fúngicas com versátil aplicabilidade industrial. Elas podem ser utilizadas para fabricação de rações de animais (Nortey et al. 2008), no processo de panificação (Jiang et al. 2008), na produção de papel (Bae et al. 2008), na produção de adoçantes como o xilitol, na indústria têxtil e na clarificação de sucos e cervejas (Polizeli et al. 2005). Devido a essa gama de aplicações práticas, o aumento da expressão de genes de xilanases e celulases em fungos como $H$. grisea, é uma área a ser explorada. 


\subsection{Sistema celulolítico do fungo Humicola grisea var. thermoidea componentes e regulação}

O gênero Humicola foi primeiramente descrito em 1914 por Traaen e colaboradores (citado por Mason 1953) e inclui quatro espécies Humicola fuscoatra, Humicola grisea, Humicola insolens e uma espécie descrita mais recentemente, Humicola phialophoroides (Ko et al., 2011).

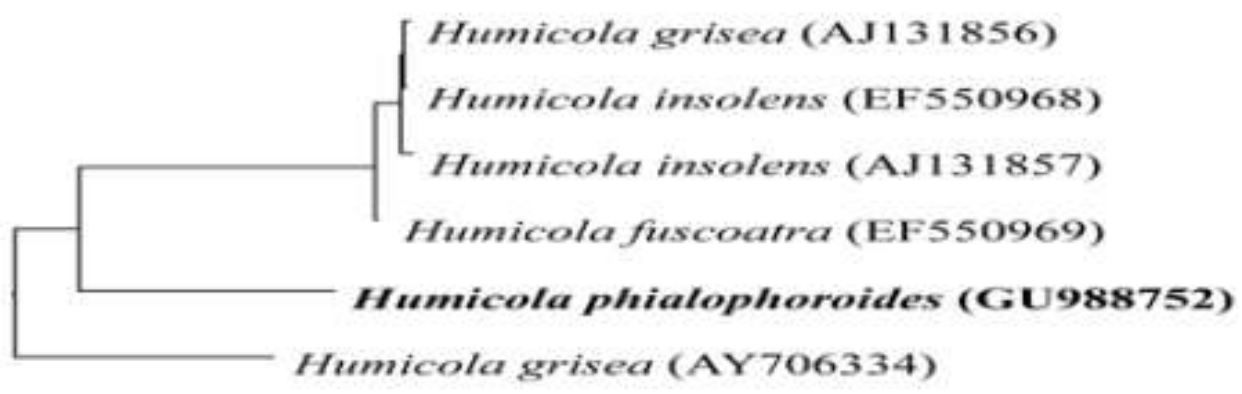

Figura 9. Árvore filogenética baseada no rDNA das espécies do gênero Humicola (Adaptado de Ko et al., 2010)

Chaves (1982) isolou uma linhagem de $H$. grisea de compostagem, a qual era capaz de produzir enzimas lignocelulolíticas em alta temperatura, devido a esta característica essa linhagem foi classificada como $H$. grisea var. thermoidea. É um fungo aeróbico e considerado um termofílico moderado com crescimento ótimo entre 40 e $42^{\circ} \mathrm{C}$ (Araújo et al., 1983).

H. grisea var. thermoidea é capaz de produzir diversas enzimas hidrolíticas termoestáveis incluindo: celulases (Azevedo et al., 1990; Poças-Fonseca et al., 1997; PoçasFonseca et al., 2000), xilanases (Da-Silva et al., 1994; Monti et al., 1991), amilases (Oliveira et al., 1991), trealases (Cardello et al., 1994 ; Zimmermann et al., 1990) e outras. Por produzir uma grande variedade de enzimas com potencial industrial, este fungo é um bom candidato para utilização na bioconversão de resíduos agrícolas (De-Paula et al., 1999 ; De-Paula et al., 2003).

Muitos genes do complexo celulolítico de $H$. grisea já foram clonados e caracterizados molecularmente: cbh1.1 (Azevedo et al., 1990), cbh1.2 (Poças-Fonseca et al., 1997), eg/1 (Takashima et al., 1996 ), eg/2 (Takashima et al., 1997), eg/3 e eg/4 (Takashima et al., 1999a) , xyn1 (likura et al., 1997), xyn2 (De-Faria et al., 2002), e bg/4 (Takashima et al., 1999b). Estes genes apresentam uma dinâmica de regulação interessante e ainda não bem compreendida no nível molecular.

Mesmo conhecendo parte dos componentes desse sistema celulolítico e como a regulação do mesmo é influenciada pela presença de fontes de carbono alternativas, mais 
estudos se fazem necessários para entender a fundo como ele ocorre, inclusive para verificar se mecanismos epigenéticos podem estar envolvidos nesse processo. Nosso grupo é pioneiro em utilizar moduladores epigenéticos e investigar seu efeito na produção de enzimas em $H$. grisea, sendo a 5-aza-2'-desoxi-citidina o foco deste trabalho.

O gene cbh1.1 de H. grisea (Azevedo et al., 1990) codifica uma celobiohidrolase (CBH 1.1) com massa molecular de $55 \mathrm{kDa}$ apresentando domínio catalítico e módulo ligação à carboidrato (CBM) enquanto cbh1.2 (Poças-Fonseca et al., 1997) codifica uma celobiohidrolase ( $\mathrm{CBH} 1.2)$ com massa molecular de $47 \mathrm{kDa}$ que possui apenas o domínio catalítico. Poças-Fonseca e colaboradores (2000), utilizando a técnica de RT-PCR, verificaram que estes dois genes apresentam padrões de expressão diferentes. O gene cbh1.1 foi mostrou-se expresso somente quando o fungo foi crescido em baixas concentrações de lactose $(0,1 \%)$ e celobiose $(0,1 \%)$, mas não foi detectada expressão gênica após crescimento em glicose $(0,1 \%$ e $1,0 \%)$, glicerol $(0,1 \%)$, xilose $(0,1 \%)$ e em uma concentração maior de celobiose (1\%). Já a expressão do gene $c b h 1.2$ foi detectada em todos esses substratos solúveis.

De Paula e colaboradores (2003) demonstraram que H.grisea quando cultivado em glicose não foi capaz de produzir níveis detectáveis de celulases, mas quando cultivado em bagaço de cana-de-açucar (BCA) e palha de cereal moída (BMS) foi possível detectar a presença de um complexo de enzimas hidrolíticas, sendo uma delas identificada como uma proteína de aproximadamente $47 \mathrm{kDa}$ e 451 resíduos de aminoácidos. Esta foi a principal enzima secretada pelo fungo quando cultivado em substratos celulolíticos e análises posteriores de homologia de aminoácidos indicaram que representa o produto do gene $c b h 1.2$, a enzima $\mathrm{CBH} 1.2(\mathrm{EC}$ 3.2.1.91). Os autores ainda obtiveram o cDNA completo correspondente ao gene cbh1.2 para posteriores análises de expressão heteróloga em outros modelos, como leveduras.

Benoliel e colaboradores (2010) expressaram em S. cerevisiae o gene bg/4 de $\mathrm{H}$. grisea, que codifica uma $\beta$-glicosidase cuja atividade não é inibida pelo produto final da reação, a glicose. A enzima recombinante foi detectada em gel desnaturante SDS-PAGE e foi possível verificar atividade enzimática de $\beta$-glicosidase no sobrenadante, porém diferentemente da enzima nativa, a recombinante apresentou atividade ótima a $40{ }^{\circ} \mathrm{C}$ e não a $50 \stackrel{\circ}{\circ} \mathrm{C}$. Tal diferença foi explicada como decorrente de um padrão de glicosilação diferente realizado pela hospedeira heteróloga.

Oliveira e colaboradores expressaram o cDNA de cbh1.2 de H. grisea em Pichia pastoris,. A enzima recombinante $(\mathrm{rCBH} 1.2)$ foi produzida e secretada eficientemente e sua atividade foi verificada em diferentes substratos, incluindo filtro de papel Whatman, CMC, celulose microcristalina (Avicel) e pNPG. A atividade ótima da enzima recombinante foi em $\mathrm{pH}$ 8 e $60^{\circ} \mathrm{C}$, apresentando tanto atividade de endoglicanase como de exoglicanase. Além disso, a enzima se mostrou altamente termoestável com $88 \%$ de atividade residual após 4 horas de incubação a $70^{\circ} \mathrm{C}$. Ainda, a enzima recombinante apresentou massa molecular similar à 
enzima nativa, demonstrando que o padrão de glicolisação da proteína foi mantido no sistema de expressão heteróloga utilizado.

likura e colaboradores (1997) isolaram um gene de xilanase de H.grisea. O gene foi denominado xyn1 e codifica a enzima XYN1 com 429 resíduos de aminoácidos e massa molecular de $47 \mathrm{kDa}$, apresentando um domínio de ligação à celulose em sua estrutura. Os autores verificaram que este gene foi ativamente expresso quando o fungo foi cultivado em xilana e Avicel.

Faria e colaboradores (2000) isolaram e caracterizaram um segundo gene de xilanase de $H$. grisea ( $x y n 2$ ) que codifica uma enzima apresentando 23kDa.. Em outro trabalho, Faria e colaboradores (2002) expressaram o cDNA correspondente ao gene xyn2 em Trichoderma e Pichia pastoris.

Nosso grupo de pesquisa (Mello-de-Sousa et al, 2011) publicou o perfil transcricional de diferentes genes de celulase, de um gene de xilanase e dos genes correspondentes aos fatores de transcrição CreA (reponsável pela repressão transcricional em presença de glicose) e PacC (reponsável pela regulação da expresão gênica em resposta a alterações de $\mathrm{pH}$ ) de $H$. grisea cultivado em meios de diferentes valores de $\mathrm{pH}$ ( 5 e 8) e em diferentes fontes de carbono (glicose e bagaço de cana-de-açúcar). Por meio da técnica de RT-qPCR, esses autores verificaram um aumento no acúmulo de transcritos de 6 genes de celulase (cbh1.1, $c b h 1.2, e g / 1, e g / 2, e g / 3, b g / 4)$ e de um de xilanase ( $x y n 1)$ quando o fungo foi cultivado na presença de BCA; tal aumento não foi verificado para o gene eg/4. Também ocorreu um aumento nos níveis dos transcritos dos genes cbh1.2, eg/1, eg/2, eg/3, bg/4 e xyn1 em pH 8 em relação a pH 5 quando o fungo foi cultivado na mesma fonte de carbono. $O$ gene creA teve aumento do acúmulo de seu mRNA em pH 5, tanto em glicose como em BCA. Maior acúmulo de transcritos correspondentes ao gene pacC ocorreu na presença de $\mathrm{BCA}$ e em $\mathrm{pH}$ 8. Tais dados ilustram a complexidade da regulação dos genes cujos produtos estão envolvidos na degradação da parede celular vegetal por $H$. grisea. A investigação detalhada dos mecanismos regulatórios envolvidos é essencial para a otimização da produção de enzimas de interesse industrial por esse fungo. 
OBJETIVOS 


\subsection{Objetivo geral}

Este trabalho teve como objetivo a análise do efeito do modulador epignético 5-aza-2'desoxi-citidina (5-AZA) sobre a secreção de enzimas e sobre a expressão de genes relacionados à degradação de substratos lignocelulósicos por H.grisea

\subsection{Objetivos específicos}

1. Avaliar as atividades enzimáticas de CMCase e de xilanase presentes nos sobrenadantes de cultura de $H$. grisea cultivado em glicose, bagaço de cana explodido a vapor, feno moído ou farelo de trigo, na presença de 25 ou $50 \mu \mathrm{M}$ de 5-AZA, pelos períodos de 2, 12 e 96 horas

2. Analisar o perfil de acúmulo de transcritos de genes de endoglicanases (eg/1 e eg/4), celobiohidrolases (cbh1.1 e cbh1.2), endoxilanases (xyn1 e xyn2) e beta-glicosidase ( $b g / 4$ ) de H. grisea cultivado em glicose, bagaço de cana explodido a vapor, feno moído ou farelo de trigo, na presença de 25 ou $50 \mu \mathrm{M}$ de 5-AZA, pelos períodos de 2, 12 e 96 horas 
MATERIAL E MÉTODOS 


\section{MATERIAIS}

\subsection{Meios para crescimento e indução enzimática do fungo}

Linhagens e cultivo do fungo

H. grisea var. thermoidea linhagem selvagem isolada do solo brasileiro (Araújo et al., 1983) foi mantida em meio sólido ágar-aveia(Quaker) $(4 \%, \mathrm{~m} / \mathrm{v})$ a $42^{\circ} \mathrm{C}$ para obtenção de esporos

\section{Meio Ágar-Aveia}

Aveia "Quacker"

$$
4 \%
$$

Ágar bacteriológico $15 \mathrm{~g}$

Água destilada (q.s.p.)

Ajustar o $\mathrm{pH}$ para 7,2

Adicionar Ampicilina para concentração de 100 mg/mL

\section{Solução de Ampicilina $(50 \mathrm{mg} / \mathrm{mL})$}

Ampicilina

Água destilada

$10 \mathrm{~mL}$

Esterilizar por filtração em membrana Millipore de 0,22 $\mu \mathrm{m}$

Sais de Pontecorvo 1X, base para Meio Mínimo e Meio Completo (Pontecorvo et al., 1953)

$\mathrm{NaNO}_{3}$

$$
6,00 \mathrm{~g}
$$

$\mathrm{KCl}$

$$
0,50 \mathrm{~g}
$$

$\mathrm{KH}_{2} \mathrm{PO}_{4}$

$1,50 \mathrm{~g}$

$\mathrm{MgSO}_{4 \cdot} \cdot 7 \mathrm{H}_{2} \mathrm{O}$

$0,50 \mathrm{~g}$

$\mathrm{ZnSO}_{4}$

$0,01 \mathrm{~g}$

$\mathrm{FeSO}_{4}$

$0,01 \mathrm{~g}$

Água destilada (q.s.p.)

Ajustar o $\mathrm{pH}$ para 6,8

Solução de Elementos Traço (2000X)

$\mathrm{C}_{6} \mathrm{H}_{8} \mathrm{O}_{7} \bullet \mathrm{H}_{2} \mathrm{O}$ (ác. cítrico monohidratado)

$\mathrm{ZnSO}_{4} \bullet 7 \mathrm{H}_{2} \mathrm{O}$ 


$\begin{array}{lc}\mathrm{Fe}\left(\mathrm{NH}_{4}\right)_{2}\left(\mathrm{SO}_{4)_{2} \bullet 6 \mathrm{H}_{2} \mathrm{O}}\right. & 1,00 \mathrm{~g} \\ \mathrm{CuSO}_{4} \bullet \mathrm{H}_{2} \mathrm{O} & 0,25 \mathrm{~g} \\ \mathrm{MnSO}_{4} \bullet \mathrm{H}_{2} \mathrm{O} & 0,05 \mathrm{~g} \\ \mathrm{H}_{3} \mathrm{BO}_{3} & 0,05 \mathrm{~g} \\ \mathrm{Na}_{2} \mathrm{MoO}_{4}-\mathrm{H}_{2} \mathrm{O} & 0,05 \mathrm{~g} \\ \text { Água destilada (q.s.p) } \quad \text { estéril } & 1000,00 \mathrm{~mL} \\ \text { Solução de Vitaminas (1000X) } & \\ \text { Ácido nicotínico } & 0,10 \mathrm{~g} \\ \text { Ácido para-aminobenzóico } & 0,01 \mathrm{~g} \\ \text { Biotina } & 0,20 \mathrm{mg} \\ \text { Piridoxina } & 0,05 \mathrm{~g} \\ \text { Riboflavina } & 0,10 \mathrm{~g} \\ \text { Tiamina } & 0,05 \mathrm{~g} \\ \text { Água destilada (q.s.p) } & 100,00 \mathrm{~mL}\end{array}$

\section{Meio Mínimo (MM) para indução}

Solução de Sais de Pontecorvo 10X $100 \mathrm{~mL}$

Água destilada (q.s.p) $\quad 1000 \mathrm{~mL}$

Ajustar o $\mathrm{pH}$ para 6,8

Acrescentar:

- Solução de Elementos Traço para 1X

- Solução de Vitaminas para 1X

Meio de crescimento de micélio (Meio completo)

Glicose 1\% $10,0 \mathrm{~g}$

Solução de Sais de Pontecorvo 10X $100,0 \mathrm{~mL}$

Peptona $0,1 \%(\mathrm{~g} / \mathrm{v})$ $1,0 \mathrm{~g}$

Extrato de levedura $0,25 \%(\mathrm{~g} / \mathrm{v})$ $2,5 \mathrm{~g}$ 
Água destilada (q.s.p)

$1000,0 \mathrm{~mL}$

Ajustar o $\mathrm{pH}$ para 6,8

Acrescentar:

- Solução de Elementos Traço $1 \mathrm{X}$

- Solução de Vitaminas $1 \mathrm{X}$

\subsection{Soluções para medição da atividade enzimática}

Solução de DNS (Miller, 1959)

Ácido dinitrosalicílico (DNS)

$10 \mathrm{~g}$

$\mathrm{NaOH} 2 \mathrm{M}$

$200 \mathrm{~mL}$

Tartarato de sódio e potássio

$300 \mathrm{~g}$

- Diluir o DNS em $200 \mathrm{~mL}$ de $\mathrm{NaOH}$ sob agitação e aquecimento

- Dissolver o tartarato de sódio e potássio em $500 \mathrm{~mL}$ de água destilada ou miliQ

- Adicionar o DNS dissolvido na solução com tartarato de sódio e potássio

- Deixar em agitação sob aquecimento até a completa dissolução dos reagentes

- Completar para $1000 \mathrm{~mL}$ com água destilada

Tampão acetato de sódio $0,05 \mathrm{M}$

Acetato de Sódio

$2,05075 \mathrm{~g}$

Água destilada (q.s.p)

$500 \mathrm{~mL}$

Ajustar o $\mathrm{pH}$ para 5,0

\section{Solução Xilana $1 \%$}

Xilana Beechwood:

$1 \mathrm{~g}$

Adicionar $20 \mathrm{ml}$ de $\mathrm{NaOH} 1 \mathrm{M}$

- $\quad$ Agitar por 30 min

Adicionar $20 \mathrm{ml}$ de $\mathrm{HCl} 1 \mathrm{M}$

- $\quad$ Agitar por 30 min

Completar o volume para $100 \mathrm{~mL}$ com tampão acetato de sódio $100 \mathrm{mM}$

Ajustar $\mathrm{pH}$ para 5 
Centrifugar por 15-20 minutos a 10.000 (separar parte solúvel da insolúvel)

Solução de C.M. C(carboximetil-celulose) $4 \%$.

CMC:

$4 \mathrm{~g}$

Tampão acetato de sódio 0,05M (q.s.p)

$100 \mathrm{~mL}$

Deixar em agitação até a completa dissolução do C.M.C

\section{Azida Sódica $10 \%(\mathrm{~m} / \mathrm{v})$}

Azida Sódica

Água destilada

Esterilizar por filtração em membrana Millipore de 0,22 $\mu \mathrm{m}$

\subsection{Soluções para gel de RNA (Materiais RNAse-free)}

Todos os materiais, soluções e reagentes utilizados para se trabalhar com RNAs estavam na condição RNAse-free.

Tampão de corrida (TBE) 10X

Trizma base

$53,885 \mathrm{~g}$

Ácido bórico

$27,5 \mathrm{~g}$

EDTA

$14,885 \mathrm{~g}$

Água destilada (q.s.p) $\quad 500 \mathrm{~mL}$

Ajustar pH para 8,4 usando Trizma base

Tampão de amostra (5x)

TBE 10X

$25 \%(v / v)$

Glicerol

$50 \%(\mathrm{v} / \mathrm{v})$

Azul de bromofenol

$0,25 \%(p / v)$

Xileno cianol

$0,25 \%(p / v)$

Gel de agarose 1\%

Agarose RNAse-free

$1,0 \mathrm{~g}$

TBE 1X

$100,0 \mathrm{~mL}$ 
Brometo de etídeo RNAse-free

Brometo de etídeo $(10 \mathrm{mg} / \mathrm{mL})$

Brometo de etídeo

$\mathrm{H}_{2} \mathrm{O}$ MilliQ

Armazenar protegido da luz
$0,5 \mu \mathrm{g} / \mathrm{mL}$

$1 \mathrm{~g}$

$100 \mathrm{~mL}$

\section{MÉTODOS}

\subsection{Indução da produção enzimático pelo fungo na presença dos diferentes substratos e em diferentes concentrações da droga}

Primeiramente, foram inoculados $10^{6}$ esporos $/ \mathrm{mL}$ do fungo $H$. grisea var.thermoidea em $250 \mathrm{~mL}$ de meio completo de Pontecorvo (MM) (Pontecorvo et al.,1953), pH 6.8 (não tamponado), enriquecido com extrato de levedura $0,25 \%(\mathrm{~m} / \mathrm{v})$, peptona $0,1 \%(\mathrm{~m} / \mathrm{v})$ e suplementado com glicose $1 \%(\mathrm{~m} / \mathrm{v})$ por $24 \mathrm{~h}\left(42{ }^{\circ} \mathrm{C} / 200 \mathrm{rpm}\right)$ para germinação de esporos. $\mathrm{O}$ micélio crescido foi então filtrado, lavado com água de torneira estéril e 3 gramas deste micélio foram então transferidos para novas alíquotas de $50 \mathrm{~mL}$ de $\mathrm{MM}$ em erlemeyers de $250 \mathrm{~mL}$, suplementados com: GLI 1\% (m/v) -condição de repressão - ou bagaço de cana-de-açúcar explodido a vapor (BCA) $0,1 \%(\mathrm{~m} / \mathrm{v})$, farelo de trigo $(\mathrm{FT}) 1 \%(\mathrm{~m} / \mathrm{v})$ e feno moído $1 \%$-condições de indução- como únicas fontes de carbono, em presença ou não (controle) de diferentes concentrações da droga 5-aza-2'-desoxi-citidina (5-AZA). As concentrações utilizadas da droga foram $25 \mu \mathrm{M}$ e $50 \mu \mathrm{M}$. Os tempos de indução utilizados neste experimento foram: $2 \mathrm{~h}, 12 \mathrm{~h}$ e $96 \mathrm{~h}$. Para $2 \mathrm{~h}$ e $12 \mathrm{~h}$ a droga foi adicionada no início do experimento, mas devido a instabilidade relatada da droga (Rogstad et al.,2009) para o tempo de 96h,o micélio ficou 84 horas crescendo sem a droga e nas 12 horas finais ela foi adicionada. Foram realizados experimentos para a escolha dos tempos de indução, da concentração da droga e da metodologia adotada (ver Resultados). Os micélios coletados foram imediatamente congelados em nitrogênio liquido e armazenados a $-80^{\circ} \mathrm{C}$ até o momento da extração. Os sobrenadantes foram coletados por centrifugação (6000 g por 20 minutos), azida sódica foi adicionada (concentração final de $0,02 \%$ ) e então armazenados a $-20 \cong \mathrm{C}$ até o momento das análises. Foram realizados três experimentos independentes .

\subsection{Droga: 5-aza-2'-desoxicitidina (5-AZA)}

5-AZA foi adquirida da Sigma-Aldrich ${ }^{\mathrm{TM}}$, diluída em água MilliQ estéril (concentração de estoque $27 \mathrm{mM}$ ) e teve sua concentração de uso determinada por curva de crescimento em meio sólido (tamanho do halo de crescimento) e meio líquido (avaliação da atividade enzimática). Para os experimentos posteriores foram utilizadas as concentrações que não 
afetaram o crescimento e atividade enzimática do fungo. A droga foi armazenada a $-20^{\circ} \mathrm{C}$ até $\mathrm{o}$ momento da indução.

\subsection{Medidas de atividade enzimática}

A atividade hidrolítica dos sobrenadantes foi determinada por ensaio colorimétrico de detecção de açúcares redutores gerados pela hidrólise do substrato, utilizando o reagente DNS (Miller, 1959). A determinação da atividade de xilanases (endoxilanases e $\beta$-D-Xilosidase) foi feita usando xilana como substratos. Os ensaios enzimáticos foram realizados com incubação de $50 \mu \mathrm{L}$ da amostra enzimática e $450 \mu \mathrm{L}$ do substrato xilana beechwood $1 \%$ por 30 minutos a $50^{\circ} \mathrm{C}$. Para os controles as amostras enzimáticas foram adicionadas após o banho. Depois do tempo da incubação as amostras foram submetidas a um choque térmico em água com gelo por 5 minutos para inativação das enzimas do substrato. Depois foram adicionados $750 \mu \mathrm{L}$ de DNS e os tubos serão imersos em banho fervente durante 5 minutos. As atividades descritas acima foram medidas espectrofotometricamente (Shimadzu UV-1800) a $540 \mathrm{~nm}$ e o resultado foi expresso em $\mu \mathrm{mol}$ de xilose formado por minuto e por $\mathrm{mL}$ de solução enzimática (Ul/mL) (Ghose, 1987). Para conversão das medições de espectrofotometria em quantidade equivalente de xilose foi realizada uma curva de calibração obtida pela leitura da absorbância de diferentes concentrações $(100 \mu \mathrm{g}$ a $500 \mu \mathrm{g} / \mathrm{mL}$ ) desse monossacarídeo com o reagente DNS (Figura 10).

A determinação da atividade de CMCase foi feita usando CMC(carboximetil-celulose) como substrato. Os ensaios enzimáticos foram realizados com incubação de $250 \mu \mathrm{L}$ da amostra enzimática e $250 \mu \mathrm{L}$ do substrato CMC $4 \%$ (Sigma-Aldrich ${ }^{\mathrm{TM}}$ ) por 60 minutos a $50^{\circ} \mathrm{C}$. Para os controles as amostras enzimáticas foram adicionadas após o banho Depois foram adicionados $750 \mu \mathrm{L}$ de DNS e os tubos imersos em banho fervente durante 5 minutos. As atividades descritas acima foram medidas espectrofotometricamente a $540 \mathrm{~nm}$ e o resultado foi expresso em $\mu \mathrm{mol}$ de glicose formado por minuto e por $\mathrm{mL}$ de solução enzimática $(\mathrm{UI} / \mathrm{mL})$ (Ghose, 1987). A curva de calibração foi realizada com diferentes concentrações de glicose $(100 \mu \mathrm{g}$ a $500 \mu \mathrm{g} / \mathrm{mL})$ (Figura 11) 


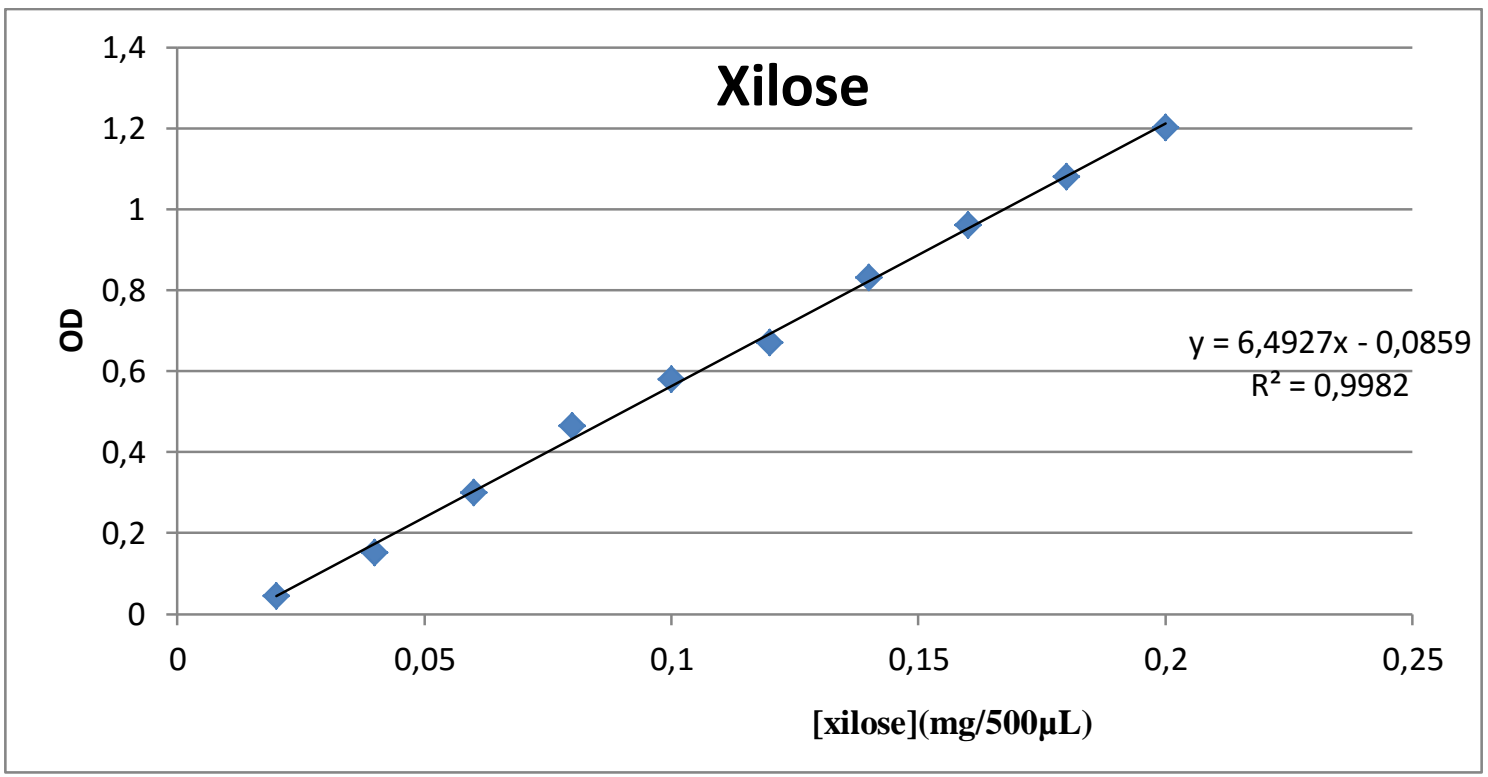

Figura 10. Curva de calibração de xilose para medição de atividade xilanolítica

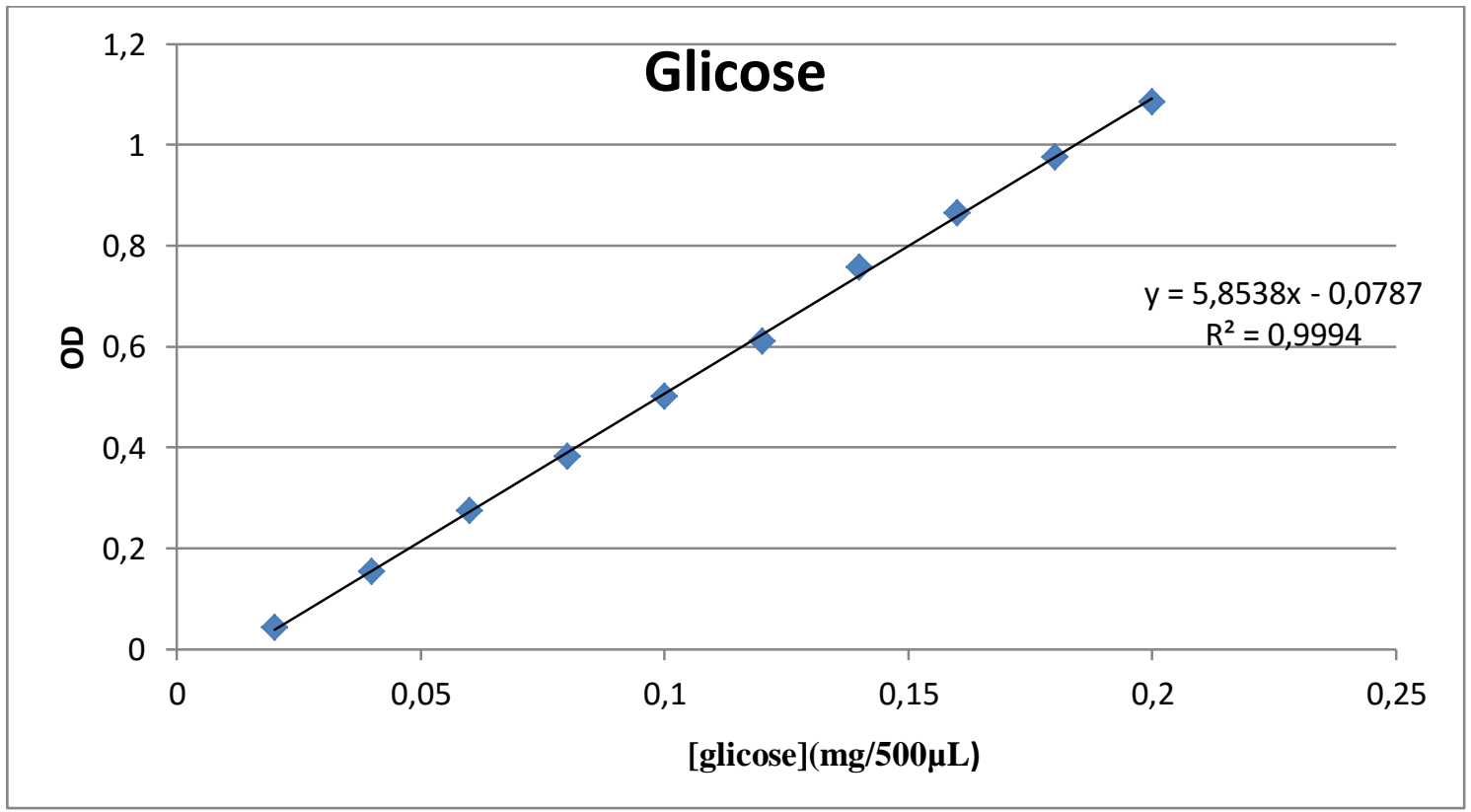

Figura 11. Curva de calibração de glicose para medição de atividade de CMCase

\subsection{Obtenção de RNA total e cDNA}

Aproximadamente $100 \mathrm{mg}$ de micélio foi macerado na presença de nitrogênio líquido até a obtenção de um pó fino. Os RNAs totais foram extraídos por meio do reagente TRIzol (Invitrogen), segundo as orientações do fabricante. Todos os materiais reagentes e soluções utilizados nesta etapa estavam na condição RNAse-free. Os RNAs obtidos foram quantificados por espectrofotometria e suas integridades avaliadas por eletroforese em gel de agarose $1 \%$. 
Para eliminação de possíveis traços contaminantes de DNA, as amostras de RNAs foram tratadas com DNAse I (RQ1 RNAse-free DNAse- Promega).

Para a obtenção dos cDNAs, reações de transcrição reversa foram realizadas utilizando-se $1,0 \mu \mathrm{g}$ de RNA total como molde, 0,5 $\mathrm{ng}$ de oligo $\mathrm{dT}_{(18)}$ e a enzima SuperScript ${ }^{\mathrm{TM}}$ III Reverse Transcriptase (Invitrogen), de acordo com orientações do fabricante. O ciclo utilizado no termociclador foi: $25 \stackrel{\circ}{ }$ C por 10 minutos, seguido por um ciclo único de 120 minutos para reação da enzima transcriptase reversa e por fim a 85 $C$ para desnaturação da enzima. Depois da reação os cDNAs foram diluídos 1:3 utilizando água MilliQ.

\subsection{Quantificação de acúmulo de transcritos por RT-qPCR}

A quantificação do acúmulo dos RNAs mensageiros transcritos nas diferentes condições de tratamento foi realizada por meio da técnica de PCR em Tempo Real, empregando-se o kit Fast SYBR ${ }^{\circledR}$ Green Master Mix (Applied Biossystems). O equipamento utilizado foi o 7500 Fast Real-Time PCR System (Applied Biosystems) com o seguinte programa: etapa inicial de desnaturação a $95{ }^{\circ} \mathrm{C}$ por 20 segundos, seguida de 40 ciclos de 95 ${ }^{\circ} \mathrm{C}$ por 3 minutos e $60^{\circ} \mathrm{C}$ por 20 segundos. As reações de amplificação foram feitas em volume final $10 \mu \mathrm{L}$, contendo $0,2 \mu \mathrm{M}$ de cada oligonucleotidio (Forward e Reverse), $5 \mu \mathrm{L}$ do Fast SYBR Green Master Mix (Applied Biosystems) e $2 \mu \mathrm{L}$ do molde de cDNA (em diluição 1:3). A análise dos perfis de expressão foi realizada pela quantificação relativa por meio da metodologia do 2 $\Delta \Delta c t$ (Livak \& Schmittgen, 2001), empregando-se o gene da actina como controle interno constitutivo. Controles negativos foram empregados utilizando água MilliQ RNAse-free em vez do molde de cDNA. Os dados foram apresentados como índices de mudança nos valores de expressão (Fold change) para cada gene. Os genes analisados foram: cbh1.1,cbh1.2,eg/1, eg/4,xyn1,xyn2, bg/4 e creA, os oligonucleotideos utilizados neste trabalho estão descritos na tabela abaixo (Mello-de-Sousa et al, 2011). O Fold change foi calculado utilizando a condição controle de cada substrato e tempo.

\begin{tabular}{|c|c|c|c|}
\hline \multirow[b]{2}{*}{ Gene } & \multirow{2}{*}{$\begin{array}{l}\text { Número de acesso no } \\
\text { GenBank }\end{array}$} & \multicolumn{2}{|l|}{ Seqüência (5' - 3') } \\
\hline & & Forward & Reverse \\
\hline$c b h 1.1$ & $(\mathrm{X} 17258.1)$ & GGTCTCAGCCGCTATCCTG & CCTCGCCGTTGATGAACTT \\
\hline cbh1.2 & (U50594. 1) & CTCATGGCCAACCAGAACA & CGCTGTTGATACCGCACTC \\
\hline egl1 & (D63516. 1) & AGTACGGCGTCACCACCAAC & GTGGAGCATCTCATAGCGGC \\
\hline egl4 & (AB003108. 1) & GCTTTGACTGGTGCGTTTCC & CACAACTTCTTCCCATCGTCTG \\
\hline$b g / 4$ & (AB003109. 1) & AAGTACCCCGACTCGATGC & TGCCGTAGAAGTCGTTGGA \\
\hline$x y n 1$ & $(\mathrm{AB} 001030.1)$ & GCGTCTTTGGCACCGACTAC & GTCCGTCTTGGCTTGGTTGT \\
\hline$x y n 2$ & (AF155594) & CTGGCACAACGGCTACTTCT & GGTGTTACGCCATCTGACCT \\
\hline
\end{tabular}

Tabela 2. Descrição dos primers utilizados neste trabalho 


\subsection{Quantificação de proteínas}

Foi empregado o método de Bradford (1976) com o reagente Kit Protein Assay (BioRad) para se determinar a concentração das proteínas nas amostras de sobrenadantes. A curva padrão foi feita utilizando o BSA (albumina sérica bovina).

\subsection{Análises estatísticas}

Todos os dados de atividade enzimática e acúmulo de transcritos foram submetidos à análise de variância (ANOVA) seguida do pós-teste de Tukey $(p<0,05)$ ou teste t não pareado com correção de Welch (quando apenas duas amostras eram comparadas) utilizando o software Graphpad Prism (versão 6.0). As amostras tratadas eram comparadas as amostras controle no mesmo tempo e substrato analisado. Nos gráficos estão apresentadas as médias dos valores obtidos, com as barras representando os desvios padrões. Asteriscos indicam diferença estatística em relação ao respectivo controle. $\left(^{*}\right) p<0,05$; $\left.{ }^{* *}\right): p<0,01 ;\left({ }^{* * *}\right): p<0,001$ 


\section{RESULTADOS E DISCUSSÃO}




\section{RESULTADOS E DISCUSSÃO}

\subsection{Determinação da sensibilidade do fungo $H$. grisea à droga 5-AZA}

O fungo $H$. grisea foi crescido em meio ágar-aveia por 120h na presença de diferentes concentrações da droga 5-AZA e o diâmetro da colônia foi medido a cada 24h (Figura 12). Não houve diferença no diâmetro da colônia e na capacidade do fungo de produzir esporos nas diferentes concentrações analisadas. Com esse experimento avaliou-se o efeito da droga no crescimento do fungo, pois a concentração a ser utilizada nos experimentos de indução enzimática não deveria afetar o crescimento do microrganismo ou ter efeito citotóxico. Em seguida, foi avaliada a atividade enzimática secretada pelo fungo crescido em meio líquido contendo diferentes substratos como única fonte de carbono, em condição controle e na presença da droga 5-AZA. A concentração utilizada para este experimento foi $25 \mu \mathrm{M}$ (Figuras 13 e 14) e o critério utilizado para a escolha dessa concentração foi o fato de não interferir no crescimento ou na formação de esporos pelo fungo.

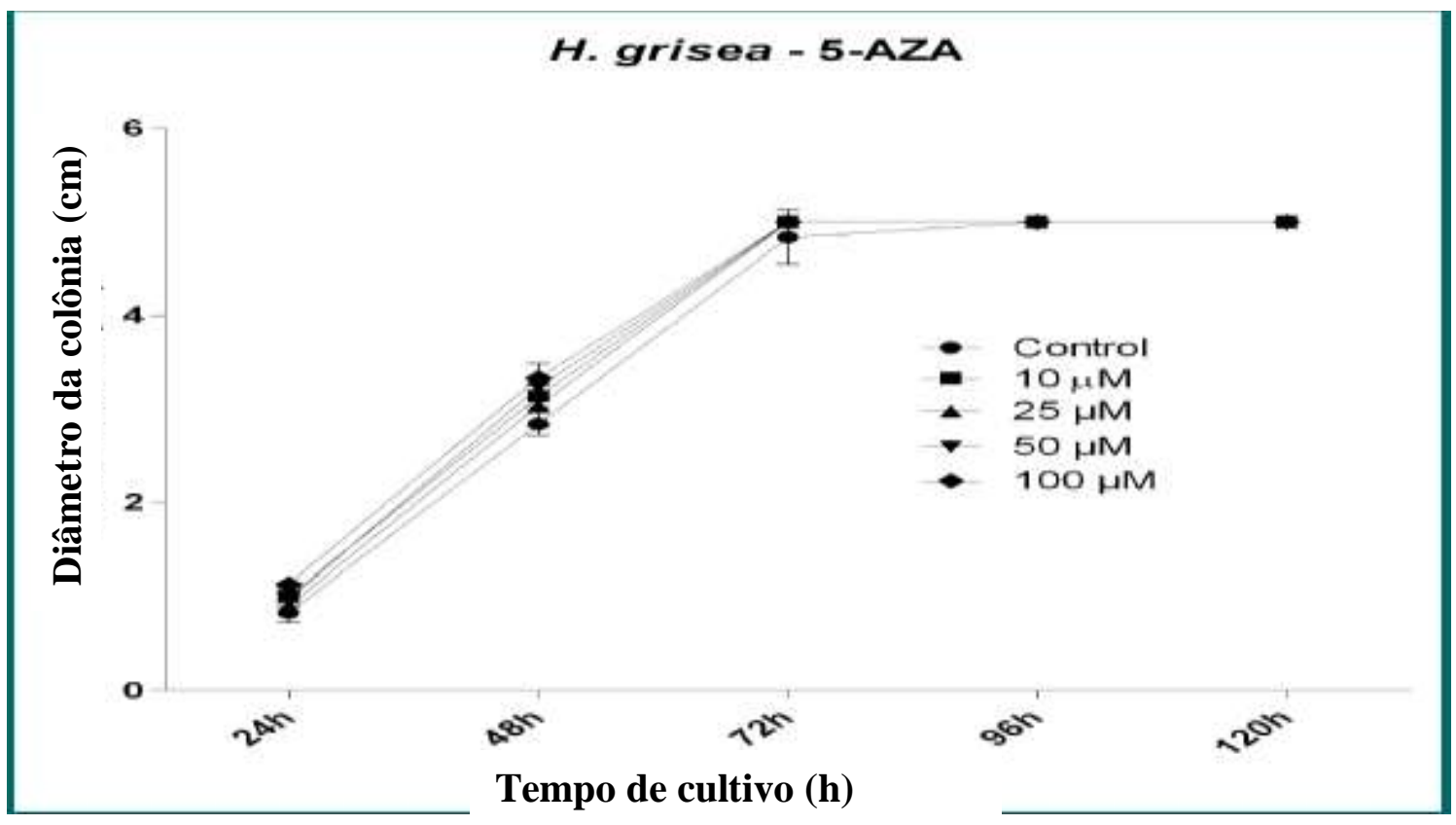

Figura 12. Curva de crescimento em meio sólido ágar-aveia do fungo $H$. grisea na presença de diferentes concentrações da droga 5-AZA. O diâmetro da colônia foi utilizado para se avaliar um possível efeito da droga sobre o crescimento do fungo.

\subsection{Seleção dos substratos a serem utilizados para indução enzimática}

Em um experimento piloto, depois de crescido em meio completo, o micélio foi exaustivamente lavado com água estéril e 3 gramas (peso úmido) foram transferidas para alíquotas de $50 \mathrm{~mL}$ de meio líquido contendo diferentes substratos como únicas fontes de carbono, na presença da droga 5-AZA $(25 \mu \mathrm{M})$ por 6 horas. Este tempo de 6 horas foi escolhido por estudos prévios realizados pelo nosso grupo que indicaram atividade enzimática detectável (dados não mostrados). As atividades de CMCase (Figura 13) e xilanases (Figura 
14) foram medidas para verificar se a droga, nestas condições, afetaria a atividade enzimática secretada pelo fungo. Foi realizado um teste $t$ não pareado com correção de Welch comparando o tratamento com o controle para as análises estatísticas.

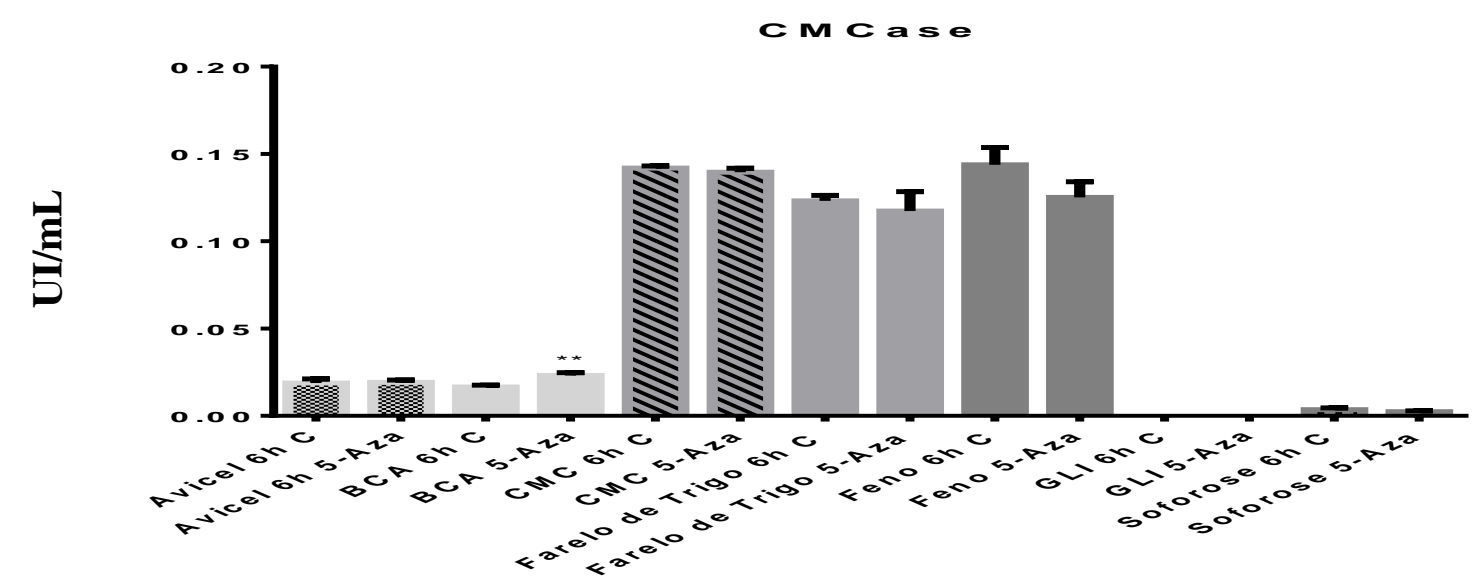

Figura 13. Atividade de CMCase do fungo $H$. grisea cultivado na presença de diferentes substratos como única fonte de carbono e na presença droga 5-AZA $\left.(25 \mu \mathrm{M}) .{ }^{(* *}\right)$ indica diferença estatística em relação ao respectivo controle, $p<0,01$.

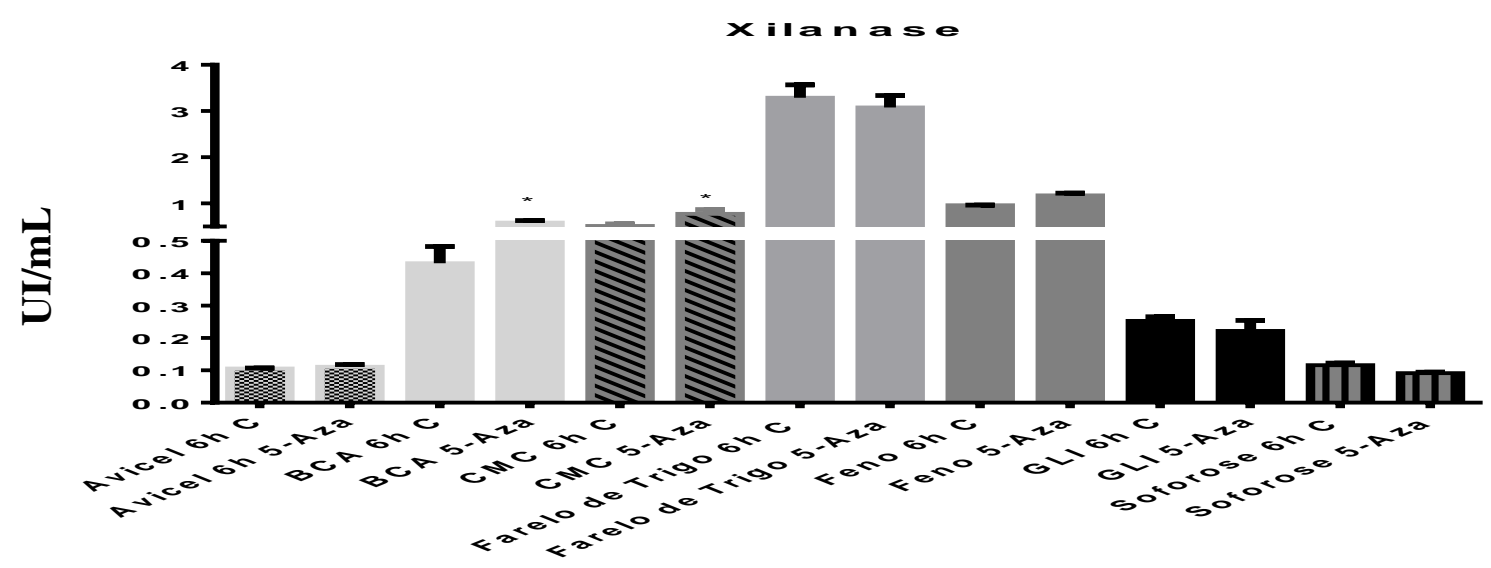

Figura 14. Atividade de xilanase do fungo $H$. grisea cultivado na presença de diferentes substratos como única fonte de carbono e na presença droga 5-AZA $(25 \mu \mathrm{M})$. ( $\left.{ }^{*}\right)$ indica diferença estatística em relação ao respectivo controle, $p<0,05$.

Para a atividade de CMCase detectada nos sobrenadantes é possível observar que os substratos que mais induziram a secreção de endoglicanases foram o CMC seguido do Feno e do FT. O tratatamento com a 5-AZA não afetou a atividade enzimática do fungo cultivado em nenhum desses substratos. Avicel e soforose foram os substratos que menos induziram a secreção de endoglicanases para o H.grisea nas condições empregadas. Não foi detectada atividade de CMCase no sobrenadante quando o fungo foi cultivado em glicose.

Para a atividade de xilanase, o FT foi o substrato que mais induziu a secreção de xilanases pelo fungo, porém o tratamento com a 5-AZA não afetou sua atividade enzimática 
quando cultivado neste substrato. Quando o fungo foi cultivado em BCA, CMC e feno a atividade de xilanase detectada nos sobrenandantes foi numericamente similar, sendo que quando cultivado em BCA e CMC a presença da 5-AZA acarretou em um aumento da atividade de xilanase detectada. Quando o H.grisea foi cultivado em Avicel e soforose a atividade de xilanase foi baixa, assim como para CMCase. Foi possível detectar certa atividade enzimática de xilanase quando o fungo foi cultivado em glicose.

Com BCA, o tratamento com a 5-AZA levou a um aumento da atividade enzimática de CMCase e xilanase. Como a atividade enzimática após crescimento em Avicel e soforose foi muito baixa, estes substratos foram descartados dos experimentos subsequentes. Apesar de a droga ter aumentado a atividade de xilanase quando o fungo foi cultivado em CMC, este substrato também foi descartado das análises posteriores, uma vez que o foco deste trabalho era avaliar o efeito da droga em resposta a indução por resíduos agrícolas. Foram escolhidos para este trabalho: BCA, feno moído, FT e glicose foi mantida como condição repressora controle.

Como o tempo de 6 horas pode ser insuficiente para a expressão e secreção de certas enzimas do complexo celulolítico e xilanolítico, foram realizadas curvas de indução com os substratos selecionados para se determinar os tempos de cultivo que levassem a atividades de CMCase e xilanase otimizadas.

\subsection{Curvas de indução enzimática do fungo $H$. grisea}

O fungo foi cultivado na presença do BCA (Figura 15), FT (Figura 16) e glicose (Figura 17) por 120 horas sem a presença da droga 5-AZA, e as atividades de CMCase e xilanase foram medidas ao longo deste período. O objetivo deste experimento foi determinar o(s) melhor(es) período(s) para as análises subsequentes. Todas as curvas foram realizadas em três experimentos independentes. 
A

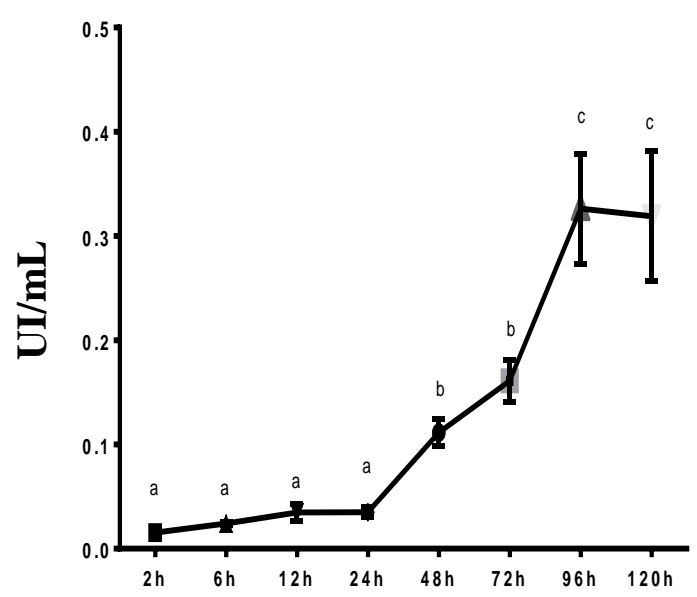

B Xilanase BCA

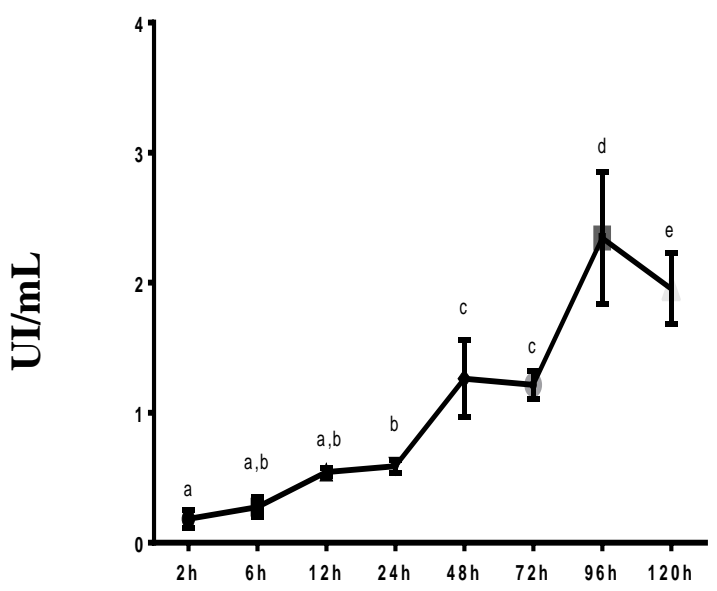

Figura 15. Atividades de CMCase (A) e xilanase (B) secretadas pelo fungo H.grisea ao longo de $120 \mathrm{~h}$ na presença do BCA como única fonte de carbono. Letras iguais denotam que não houve diferença estatística

A partir da análise das curvas de indução na presença do BCA é possível notar um pico das atividades de CMCase e xilanases após 96 horas de crescimento, sendo este tempo selecionado para as próximas análises com este substrato. O mesmo experimento foi realizado com o farelo de trigo (FT) como única fonte.

CMCase FT

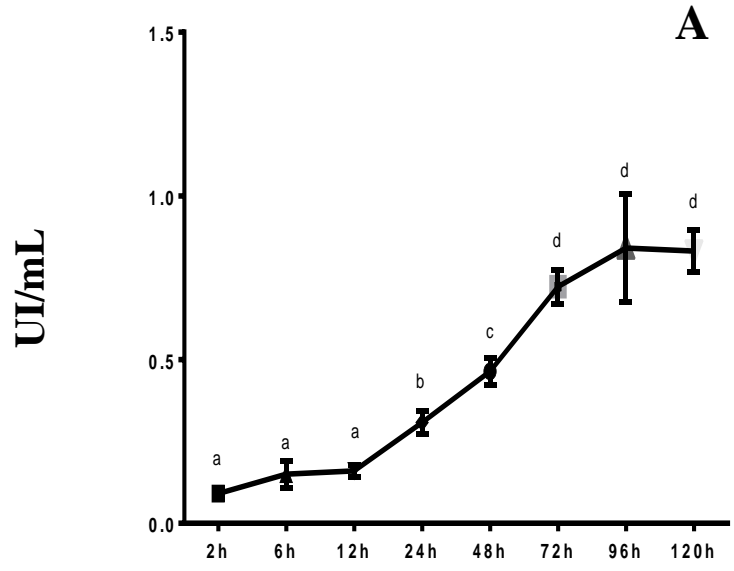

Xilanase FT

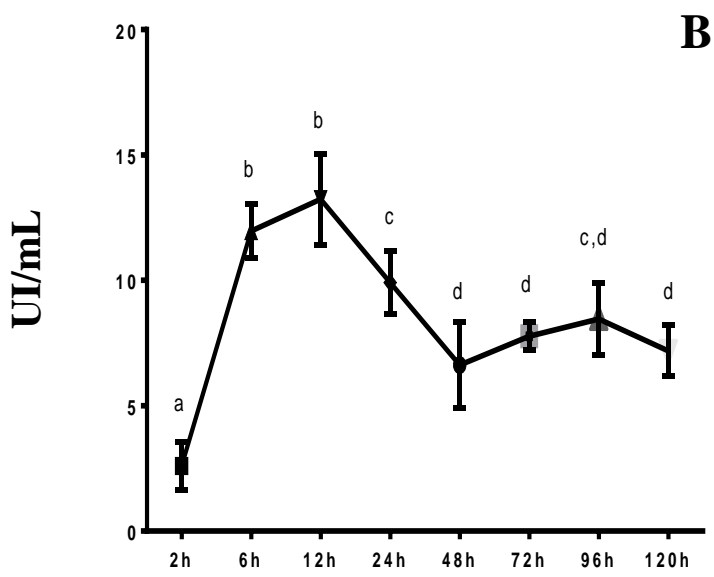

Figura 16. Atividades de CMCase (A) e xilanase (B) do fungo $H$. grisea ao longo de $120 \mathrm{~h}$ na presença do FT como única fonte de carbono. Letras iguais denotam que não houve diferença estatística.

O perfil de atividade de CMCase para BCA e FT foi similar, com o pico desta atividade após 96 horas, mas para a atividade de xilanase quando cultivado em FT, a maior atividade foi detectada nas primeiras 12 horas de crescimento. Para BCA, manteve-se o pico de atividade 
de xilanase em 96 horas. Esta diferença pode ser fruto da composição química de cada um destes substratos, que não apresentam a mesma proporção celulose/hemicelulose.

Menon e Rao (2012), em uma revisão, comparam a composição química de diversos substratos e verificam que para BCA o teor de celulose varia de $25-45 \%$ e de hemicelulose varia de $28-32 \%$. Para o farelo de trigo, a hemicelulose é mais abundante, variando de $35-39 \%$ da composição deste substrato, enquanto o teor de celulose varia de 10,5-14,8\%. Estes números explicam porque quando o fungo é cultivado em farelo de trigo ocorre um pico de atividade de xilanase no início da curva de indução e o mesmo não é verificado quando ele cresce em BCA.

A última curva de indução foi realizada com glicose como única fonte de carbono, sendo este substrato considerado repressor da transcrição dos genes de algumas enzimas do sistema celulolítico de H. grisea (Poças-Fonseca et al., 2000).

CMCase GLI

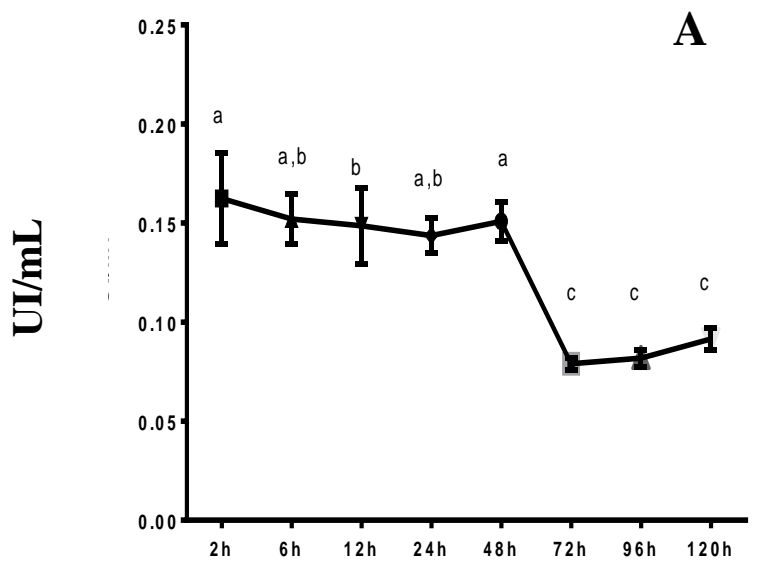

Xilanase GLI

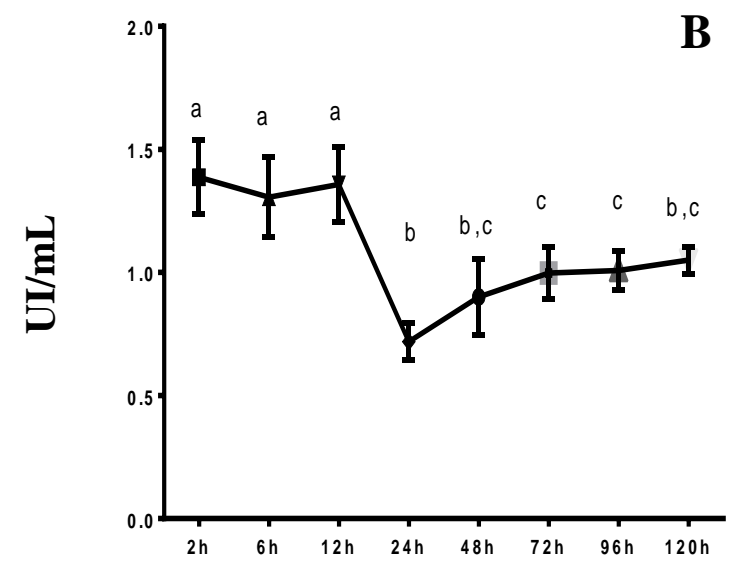

Figura 17. Atividades de CMCase (A) e xilanase (B) do fungo $H$. grisea ao longo de $120 \mathrm{~h}$ na presença de glicose como única fonte de carbono. Letras iguais denotam que não houve diferença estatística

A glicose é considerada um repressor da transcrição da maioria dos genes de enzimas do complexo celulolítico de fungos, uma vez que, se prontamente disponível para consumo, representaria um desperdício energético para o fungo secretar enzimas cuja função é gerar glicose (revisto em Ruijiter e Visser, 1997). Porém, mesmo na presença de glicose existe certa atividade enzimática basal que pode ser observada nos gráficos acima, sendo em $(A)$ a partir de 72 horas e em (B) a partir de 48 horas. Tanto a repressão que a glicose exerce no sistema celulolítico quanto a redução da velocidade de crescimento do H.grisea podem explicar essa queda repentina nas atividades de CMCase e xilanases detectadas nos sobrenadantes quando o fungo foi cultivado em glicose. Também é necessário levar em conta que ocorre transcrição basal de alguns genes de celulase mesmo quando $H$. grisea cresce em glicose como única fonte de carbono (Poças-Fonseca et al., 2000; Mello-de-Sousa et al., 2011) e que proteínas 
apresentando atividade enzimática podem ser detectadas nos sobrenadantes de cultura (DePaula et al., 2003).

Com base nos dados apresentados nas figuras 15,16 e 17, assim como em dados anteriores de nosso grupo de pesquisa, os tempos de $12 \mathrm{~h}$ e $96 \mathrm{~h}$ foram escolhidos para as análises seguintes. O tempo de 12 horas foi selecionado em razão do pico de atividade de xilanase na presença do FT e o tempo de 96 horas em razão dos picos de atividade de CMCase verificados tanto em BCA como em FT.

A droga 5-AZA apresenta instabilidade química em meio aquoso, e em pH neutro e temperatura fisiológica sua meia vida pode variar de 3 a 21 horas (Rogstad et al., 2009). Como em nossos experimentos utilizamos a temperatura de $42 \stackrel{\circ}{\circ} \mathrm{C}$, que é a temperatura ideal de crescimento para $H$. grisea, também realizamos uma curva de indução ao longo de 24 horas com BCA como única fonte de carbono, em presença de 5-AZA $25 \mu \mathrm{M}$ (Figura 18). As atividades de CMCase e Xilanase foram medidas de 6 em 6 horas; o objetivo foi verificar se a droga ainda exerceria algum efeito depois de $21 \mathrm{~h}$ em solução a $42{ }^{\circ} \mathrm{C}$, uma vez que o tempo de crescimento para os próximos experimentos seria de $96 \mathrm{~h}$.
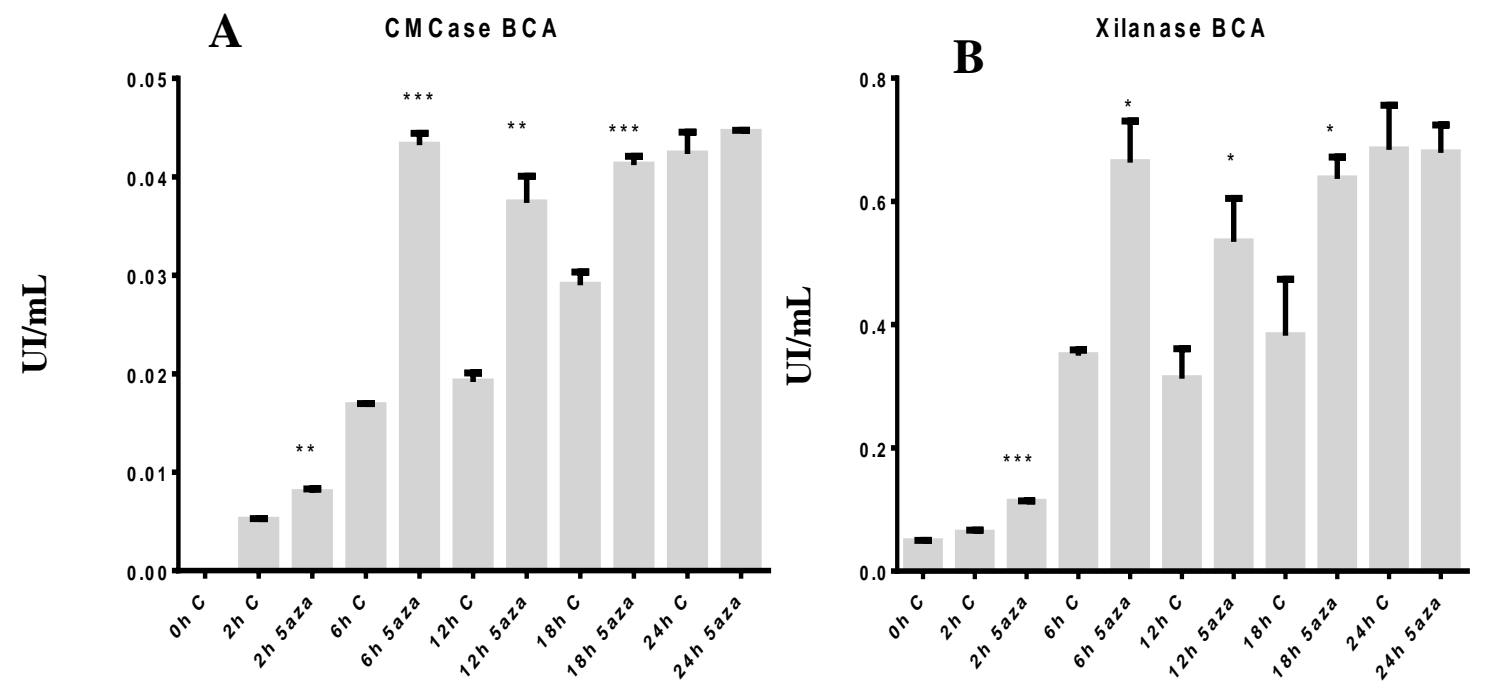

Figura 18. Atividades de CMCase (A) e xilanase (B) do fungo $H$. grisea ao longo de $24 \mathrm{~h}$ na presença de 5-AZA, tendo o BCA como fonte de carbono. Teste t não pareado com correção de Welch comparando o tratamento com o controle para as análises estatísticas. Asteriscos indicam diferença estatística em relação ao respectivo controle. $\left.\left({ }^{*}\right) p<0,05 ;\left({ }^{* *}\right): p<0,01 ;{ }^{(* *}\right)$ : $p<0,001$.

Como apresentado na Fig. 18, houve um aumento nas atividades de CMCase e xilanase em 2, 6, 12 e 18 horas em presença de 5-AZA $25 \mu \mathrm{M}$, porém no tempo de 24 h este aumentou não foi observado. Dessa forma, é possível que, nas condições empregadas nos experimentos, a droga perca seu efeito a partir de $18 \mathrm{~h}$ dado compatível com a meia vida de 21 horas proposta por Rogstad e colaboradores (2009). A partir deste experimento, e levando-se 
em conta o tempo ótimo de 96 horas para a indução enzimática, uma metodologia diferente passou a ser empregada para esse tempo de cultivo: procedeu-se ao crescimento do fungo sem a droga por 84 horas, após as quais essa foi acrescentada na concentração apropriada. Acreditamos assim que a droga 5-AZA presente nos cultivos ainda se encontrasse ativa quando da coleta das amostras de sobrenadante e de micélio.

Uma vez definidas as concentrações de uso, os tempos de indução enzimática, os substratos a serem utilizados e o desenho experimental, uma análise refinada de atividade enzimática e de acúmulo de transcritos foi realizada. $O$ fungo $H$. grisea var. thermoidea foi cultivado por 2, 12 e 96 horas, na presença ou não de duas diferentes concentrações da droga 5-AZA ( $25 \mu \mathrm{M}$ e $50 \mu \mathrm{M}$ ) tendo BCA, feno moído, FT ou glicose como únicas fontes de carbono. Nos tempos de 2 e 12 horas a droga estava presente desde a germinação dos esporos, enquanto que para o período de 96 horas de crescimento a droga foi adicionada nas 12 horas finais de cultivo. Foram realizados 3 experimentos biológicos independentes para cada substrato e os ensaios enzimáticos foram realizados em triplicata técnica.

\subsection{Determinação da atividade de CMCase nos sobrenadantes de cultura de H.grisea crescido na presença de 5-AZA}

As atividades de CMCase e xilanase foram determinadas nos sobrenadantes de cultura após crescimento do fungo $H$. grisea por 2, 12 e 96 horas, em meio mínimo suplementado com $\mathrm{BCA}$, feno moído, FT ou glicose, na presença ou não de 5-AZA $25 \mu \mathrm{M}$ ou $50 \mu \mathrm{M}$.

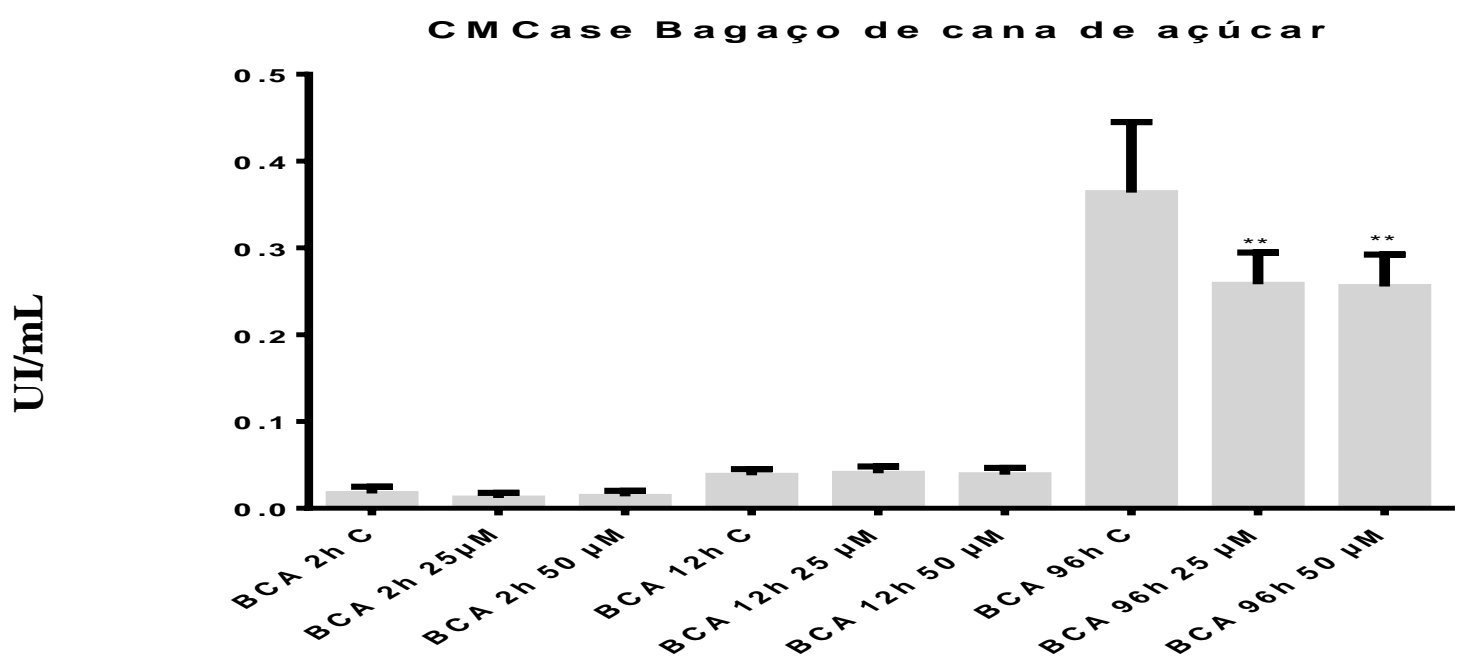

Figura 19. Atividade de CMCase nos sobrenadantes de cultura do fungo $H$, grisea cultivado em BCA e na presença de 5-AZA por 2, 12 e 96 horas. $\left({ }^{* *}\right)$ indica diferença estatística em relação ao respectivo controle, $p<0,01$.

A Fig. 19 indica que, para os tempos de 2 e 12 horas, a presença da droga não levou a modificação de atividade de CMCase nos sobrenadantes de cultura, porém em 96 horas foi possível verificar uma diminuição desta atividade enzimática, tanto na concentração de $25 \mu \mathrm{M}$ quanto $50 \mu \mathrm{M}$. 


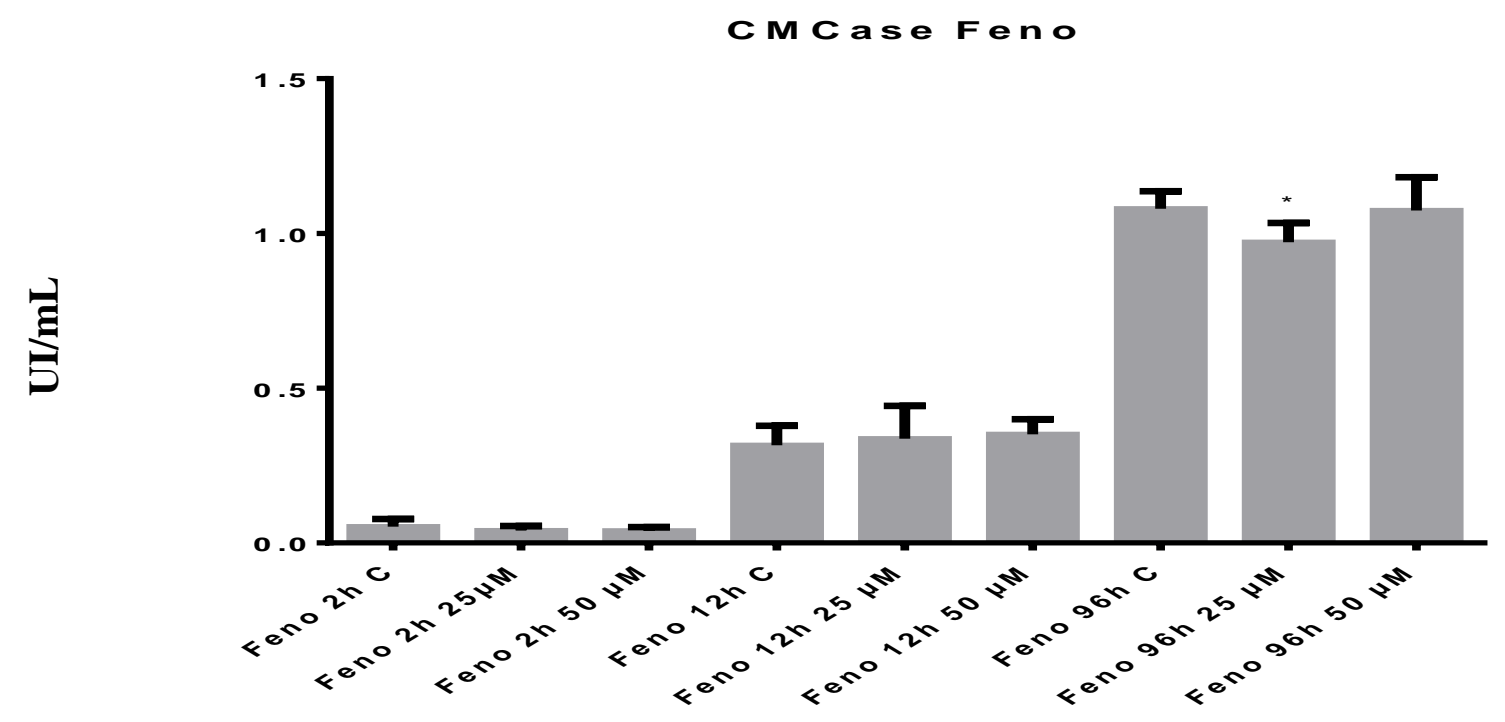

Figura 20. Atividade de CMCase nos sobrenadantes de cultura do fungo $H$. grisea cultivado em feno moído e na presença de 5-AZA por 2, 12 e 96 horas. (*) indica diferença estatística em relação ao respectivo controle, $p<0,05$.

Quando o feno moído foi utilizado como substrato, a presença de 5-AZA na concentração de $25 \mu \mathrm{M}$ coincide com uma diminuição da atividade de CMCase presente no sobrenadante de cultura com $96 \mathrm{~h}$ de crescimento; para as outras condições não houve diferença estatística.

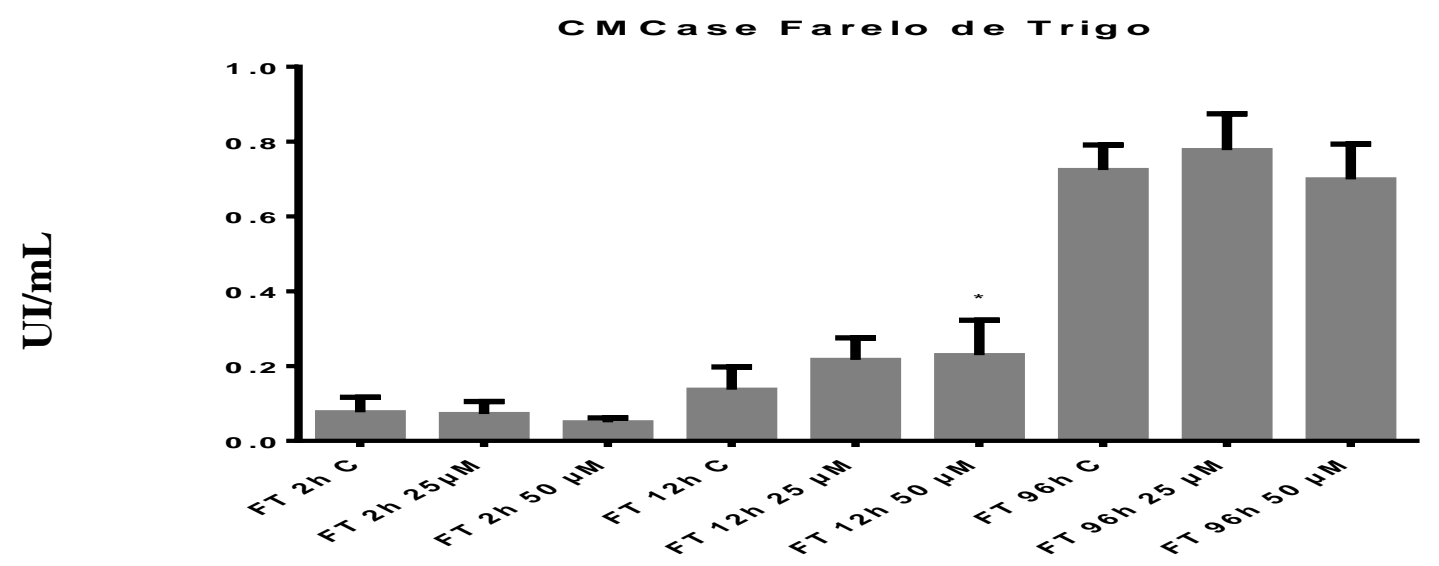

Figura 21. Atividade de CMCase nos sobrenadantes de cultura do fungo $H$. grisea cultivado em FT e na presença de 5-AZA por 2, 12 e 96 horas. ( $\left(^{*}\right)$ indica diferença estatística em relação ao respectivo controle, $p<0,05$.

No tocante à atividade de CMCase induzida pelo substrato FT, observou-se um aumento com $12 \mathrm{~h}$ de cultivo na presença de 5-AZA $50 \mu \mathrm{M}$. Não se observou diferença estatisticamente significativa para as demais condições experimentais. 


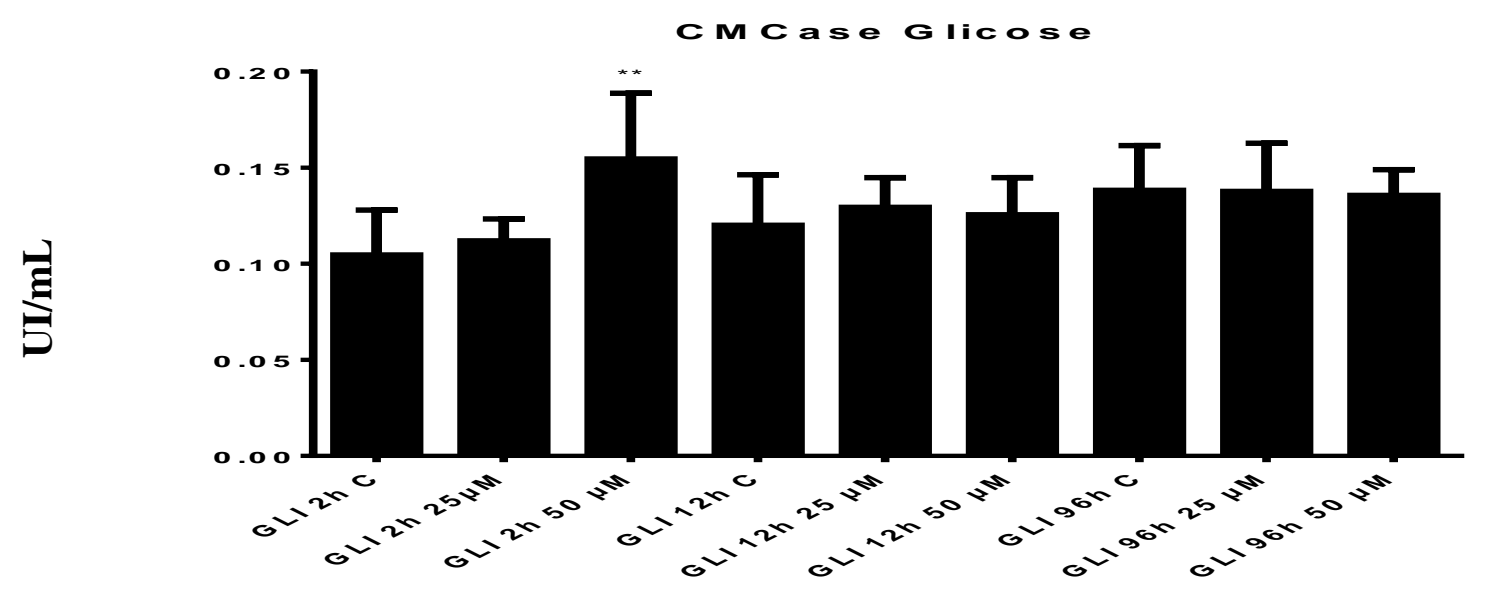

Figura 22. Atividade de CMCase nos sobrenadantes de cultura do fungo $H$.grisea cultivado em glicose e na presença de 5-AZA por 2, 12 e 96 horas. $\left(^{(\star}\right)$ indica diferença estatística em relação ao respectivo controle, $p<0,01$.

Um aumento da atividade de CMCase foi detectado quando o fungo $H$. grisea foi crescido em glicose como única fonte de carbono na presença de 5-AZA $50 \mu \mathrm{M}$ por $2 \mathrm{~h}$. Não foram observadas diferenças estatisticamente significativas para as demais condições experimentais.

A atividade de CMCase está diretamente relacionada com a ação de endoglicanases, que atuam na parte amorfa da celulose. $H$. grisea apresenta em seu arsenal enzimático pelo menos 4 endoglicanases diferentes caracterizadas (Takashima et al, 1996, 1997 e 1999a). Dessa forma, é plausível que os genes correspondentes sejam regulados de maneiras diferentes, inclusive com a metilação do DNA atuando nesta regulação. Como abordado anteriormente, a droga 5-AZA é um inibidor da ação da enzima DNMT que, ao transferir grupamentos metil para citosinas seguidas de guaninas na molécula de DNA, pode levar à repressão da transcrição gênica. Para avaliar se as diferenças de atividade de CMCase encontradas em nosso trabalho estão relacionadas à expressão diferencial de genes, foram posteriormente avaliados, por RT-qPCR, os acúmulos de transcritos de genes de endoglicanase (eg/1 e eg/4) e de celobiohidrolase (cbh1.1 e cbh1.2), uma vez que já foram descritas enzimas bi-funcionais (Oliveira et al., 2013).

Ainda que a droga 5-AZA, nos mais diferentes modelos experimentais, esteja descrita na literatura científica como atuando sobretudo sobre a molécula de DNA, não se pode descartar que essa atue também diretamente sobre a atividade enzimática. Estudos de enzimologia e química de proteínas elaborados se fazem necessários para esclarecer essa questão.

5.5. Determinação da atividade de xilanase nos sobrenadantes de cultura de $\boldsymbol{H}$. grisea crescido na presença de 5-AZA 
A atividade de xilanase secretada nos sobrenadantes de cultura de $H$. grisea também foi avaliada para os substratos BCA, FT, feno moído e glicose.

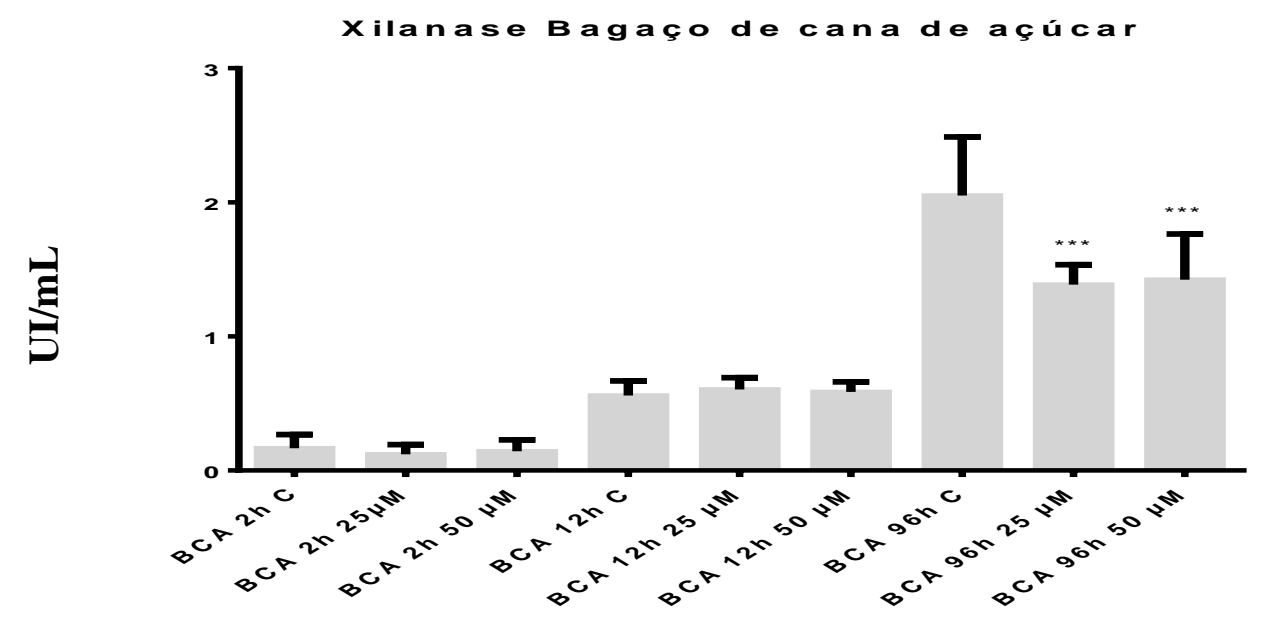

Figura 23. Atividade de xilanase nos sobrenadantes de cultura do fungo $H$. grisea cultivado em BCA e na presença de 5-AZA por 2, 12 e 96 horas. $\left(^{* * *}\right)$ indica diferença estatística em relação ao respectivo controle, $p<0,001$.

Em crescimento em BCA (Fig. 27), a presença da droga coincide com uma diminuição na atividade enzimática para ambas as concentrações no período de $96 \mathrm{~h}$, não havendo modificação em 2 e $12 \mathrm{~h}$, similarmente ao que foi verificado para a atividade de CMCase (Fig. 19).

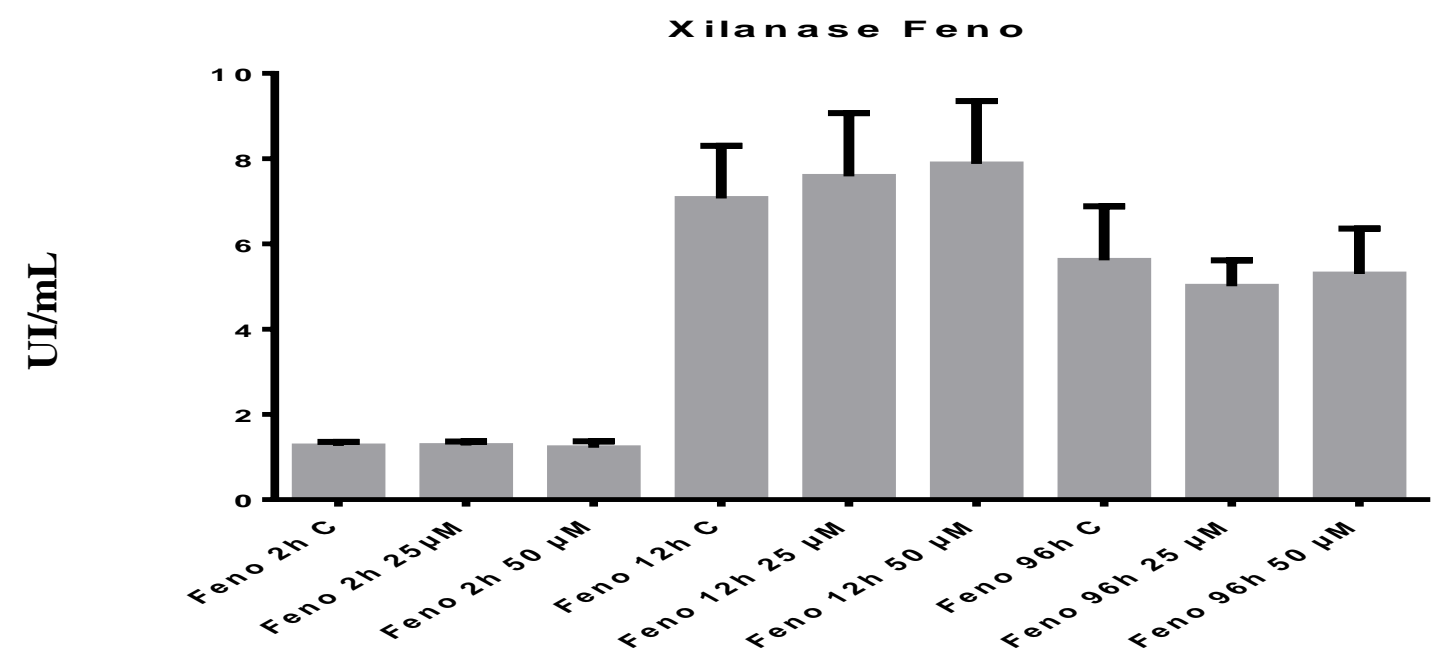

Figura 24. Atividade de xilanase nos sobrenadantes de cultura do fungo $H$. grisea cultivado em feno moído e na presença de 5-AZA por 2, 12 e 96 horas.

Durante o crescimento em feno (Figura 28), o tratamento com a 5-AZA não se mostrou relacionado a mudança alguma de atividade de xilanase. 


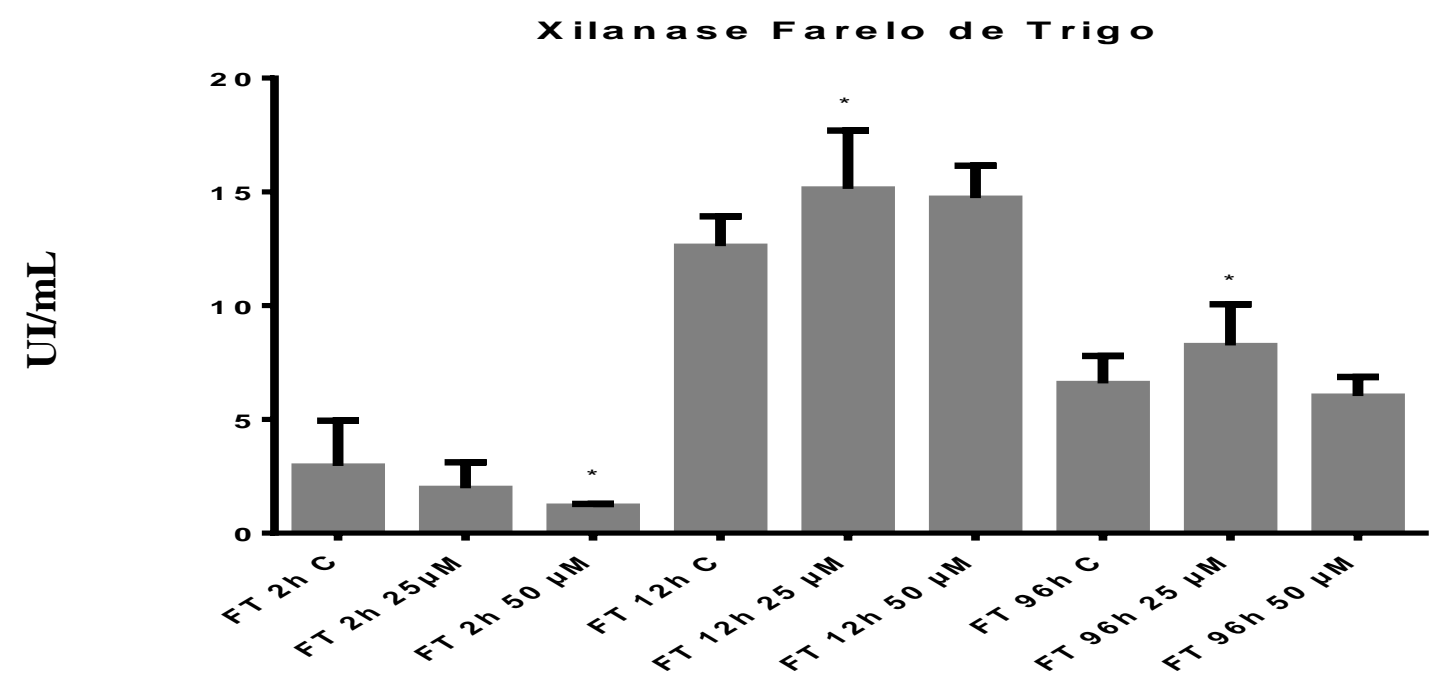

Figura 25. Atividade de xilanase nos sobrenadantes de cultura do fungo $H$, grisea cultivado em FT e na presença de 5-AZA por 2, 12 e 96 horas. $\left(^{*}\right)$ indica diferença estatística em relação ao respectivo controle, $p<0,05$.

O substrato em que, em presença da 5-AZA, mais se observou alteração na atividade de xilanase foi o farelo de trigo (Figura 29). Em 2 h, nota-se uma diminuição desta atividade na concentração de $50 \mu \mathrm{M}$. Por outro lado, em 12 e 96 horas de cultivo, houve um aumento da atividade xilanolítica com a concentração de $25 \mu \mathrm{M}$.

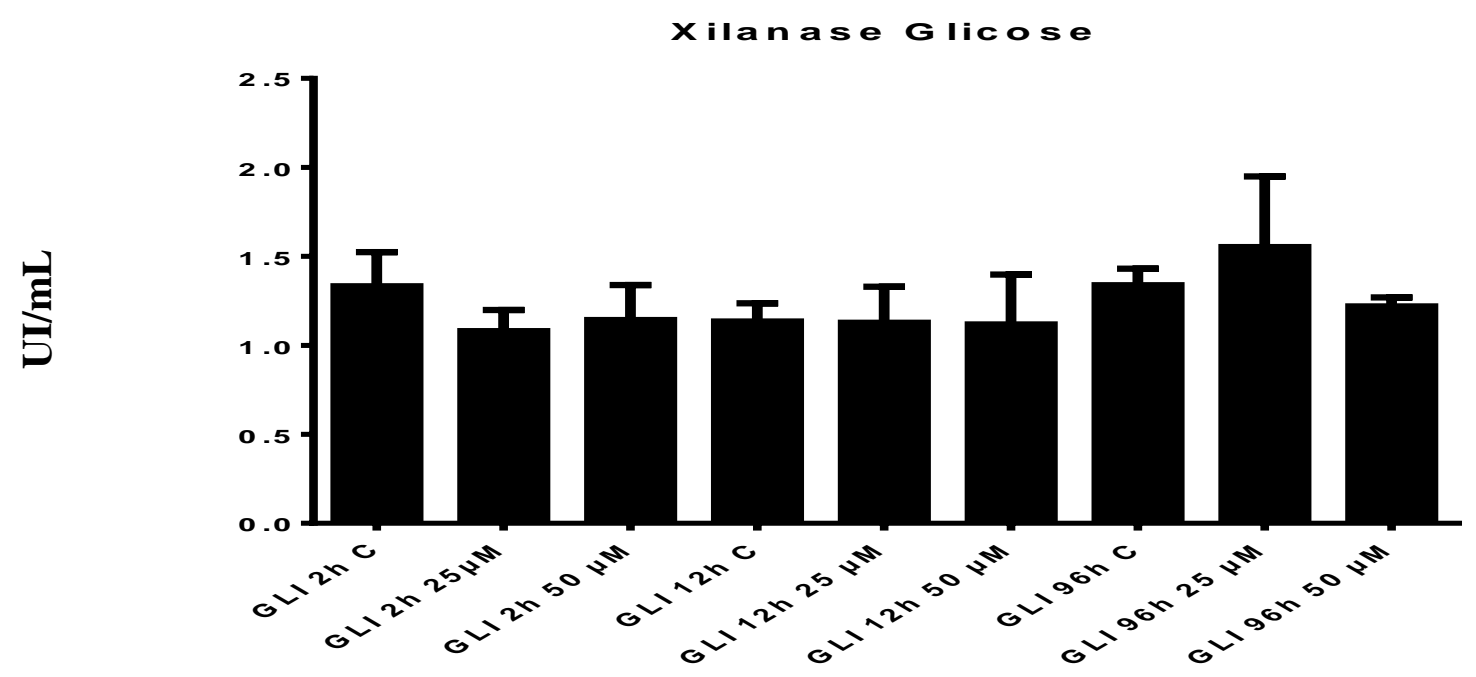

Figura 26. Atividade de xilanase nos sobrenadantes de cultura do fungo $H$, grisea cultivado em glicose e na presença de 5-AZA por 2, 12 e $96 \mathrm{~h}$.

Assim como no caso do feno moído (Fig 28), a presença da 5-AZA durante o crescimento em glicose (Figura 30) não alterou a atividade de xilanase em nenhum dos tempos analisados. 


\subsection{Efeito da 5-AZA na produção de proteínas}

Também foi determinada a quantidade de proteínas totais presentes nos sobrenadantes referentes a cada uma das amostras utilizadas nas análises de RT-qPCR apresentadas posteriormente nesse trabalho. Os gráficos apresentados na Fig. 27 representam os resultados obtidos para a quantificação do conteúdo de proteínas totais secretadas nos três experimentos independentes realizados. O método de Bradford foi empregado para quantificação das proteínas.

A

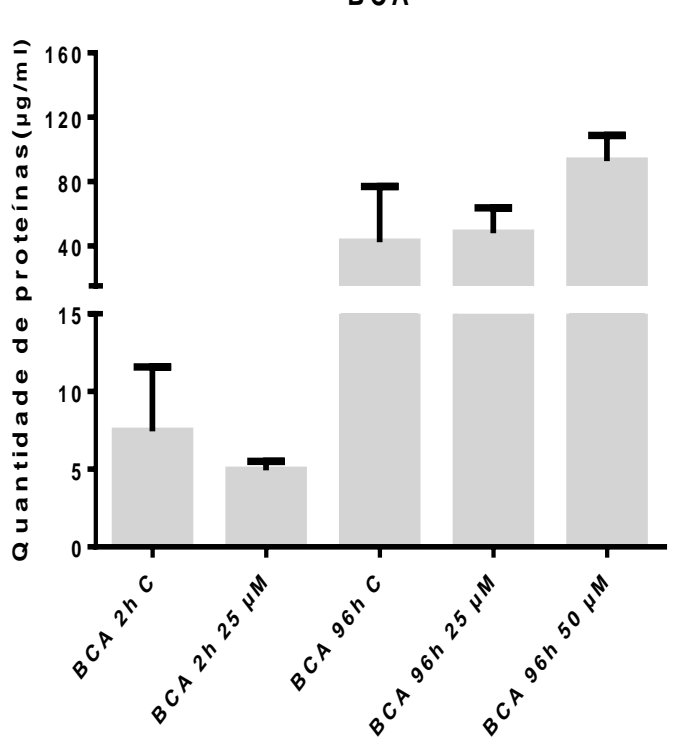

C

F T

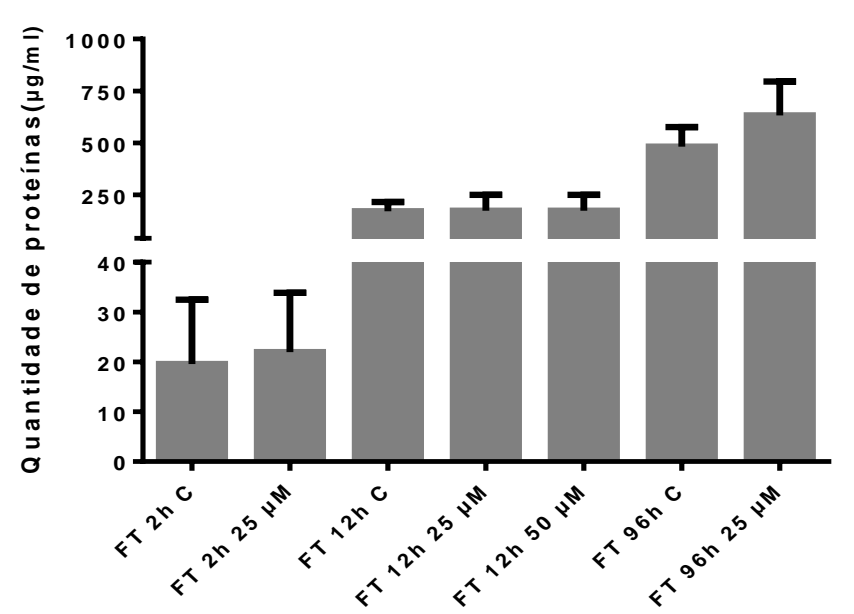

B

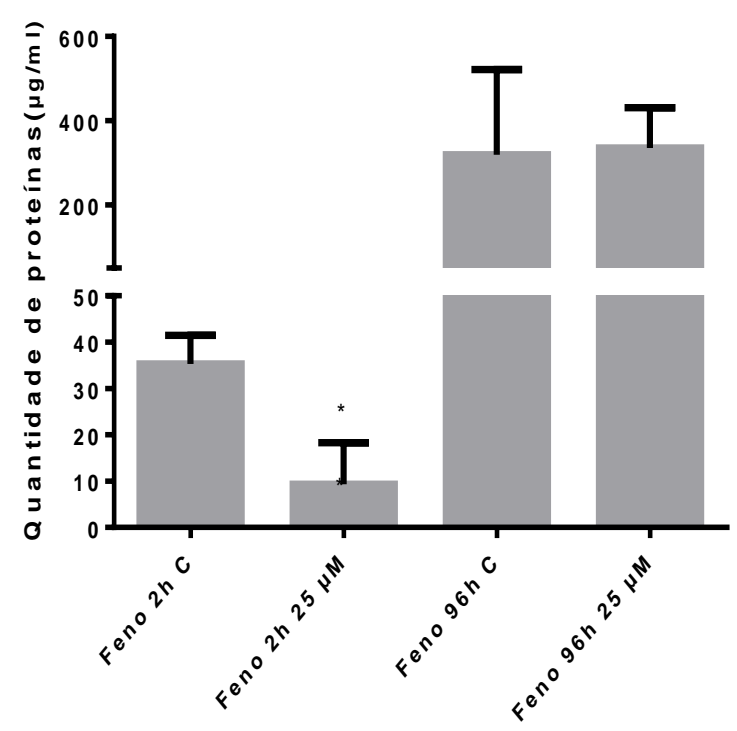

D

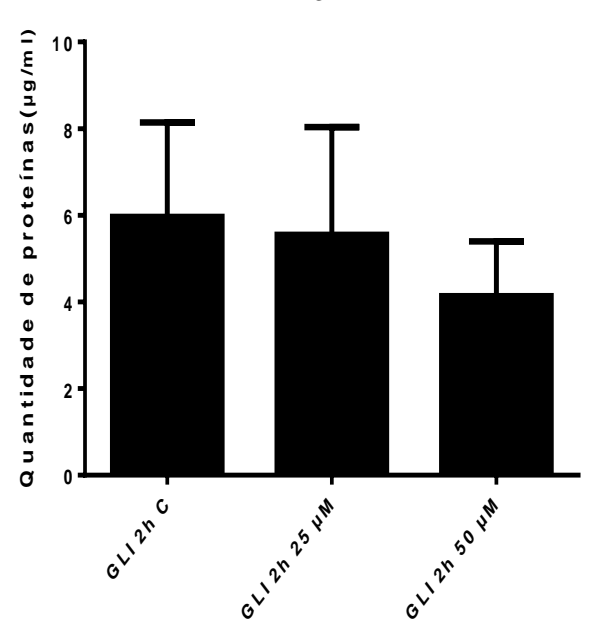

Figura 27. Quantificação das proteínas totais presentes nos sobrenadantes nas diferentes condições analisadas por RT-qPCR. $\left(^{*}\right)$ indica diferença estatística em relação ao respectivo controle, $p<0,05$. 
A quantidade de proteínas totais secretada pelo fungo $\mathrm{H}$. grisea foi afetada pela droga apenas quando do cultivo em feno moído pelo período de 2 horas $(25 \mu \mathrm{M})$. Para os demais substratos e tempos de cultivo essa quantidade permaneceu igual à da amostra controle sem a droga. Tais dados sugerem que os efeitos verificados, em presença da 5-AZA, quanto à atividade enzimática reflitam a ação direta da droga sobre a função da enzima e/ou a modulação da expressão gênica e não um efeito indireto sobre a produção protéica de forma geral.

\subsection{Efeito da 5-AZA sobre o de acúmulo de transcritos de genes de endoglicanases}

Para extração de RNA total, visando aos experimentos de RT-qPCR, foram selecionadas as amostras que apresentaram significância estatística nos ensaios enzimáticos. Não se pode, no entanto, desconsiderar que a taxa de degradação do mRNA, os mecanismos de estabilização do mRNA, a taxa de tradução, as modificações pós-traducionais e as vias de secreção exerçam papel nessa regulação (Poças-Fonseca, MJ. Tese de Doutorado em Biologia Molecular, 2000). Dessa maneira, tomamos o cuidado, nesse trabalho, de não correlacionar diretamente os efeitos que verificamos nos níveis de atividade enzimática e o acúmulo de transcritos.

Todas as amostras de RNA utilizadas nesta etapa tiveram sua integridade avaliada por eletroforese em gel de agarose, tomando por parâmetro os RNAs ribossomais 28 e 18S, foram tratadas com DNAse para remoção completa de DNA contaminante, reavaliados por eletroforese (dados não mostrados) e só então convertidas em moléculas de cDNA. Os primeiros genes analisados por RT-qPCR foram de endoglicanases: eg/1(Fig. 28) e eg/4 (Fig. 29). 
A

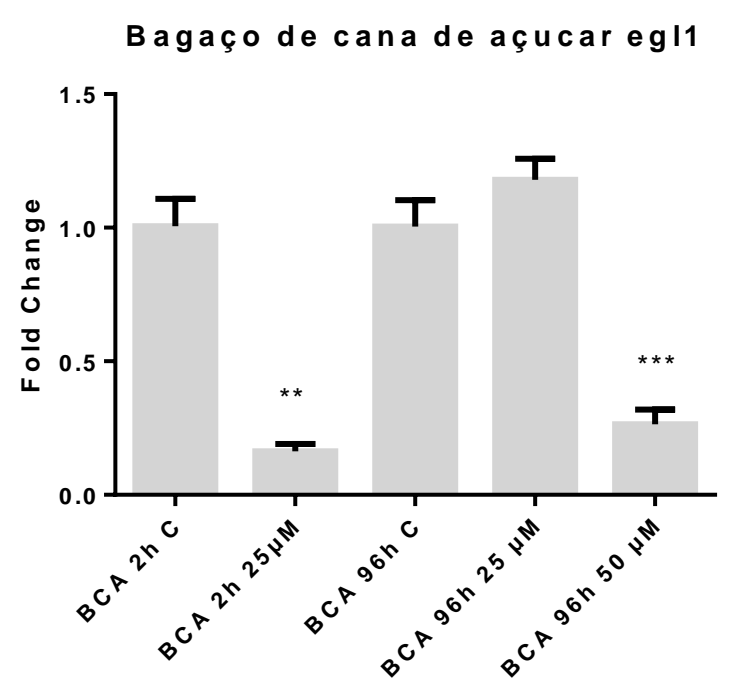

C

Farelo de Trigo egl1

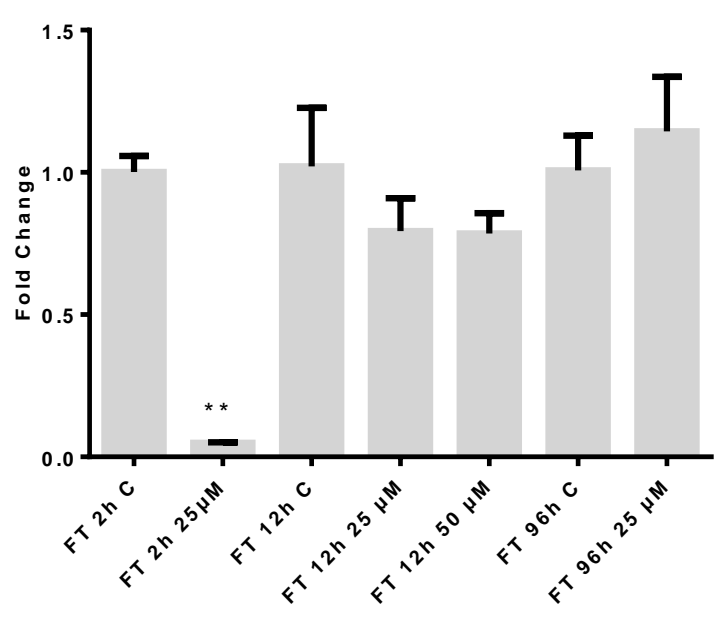

B

Feno Moído egl1

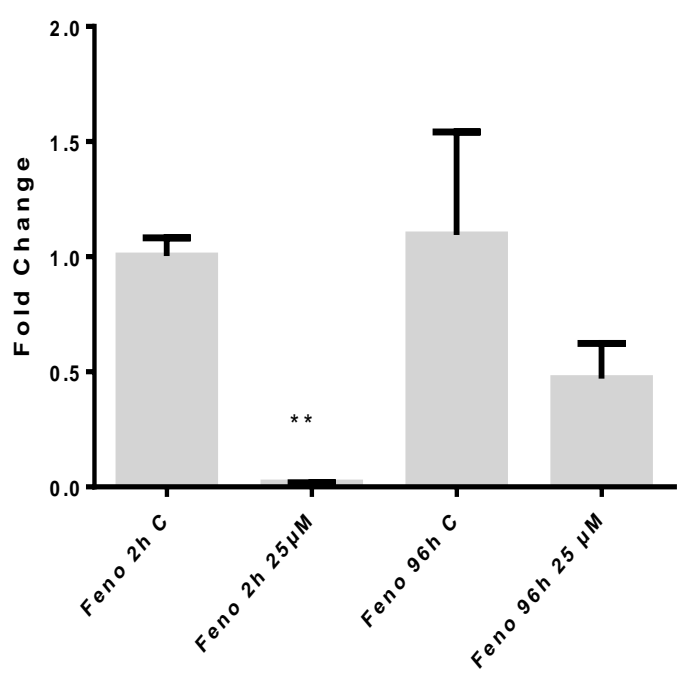

D

Glicose eg/1

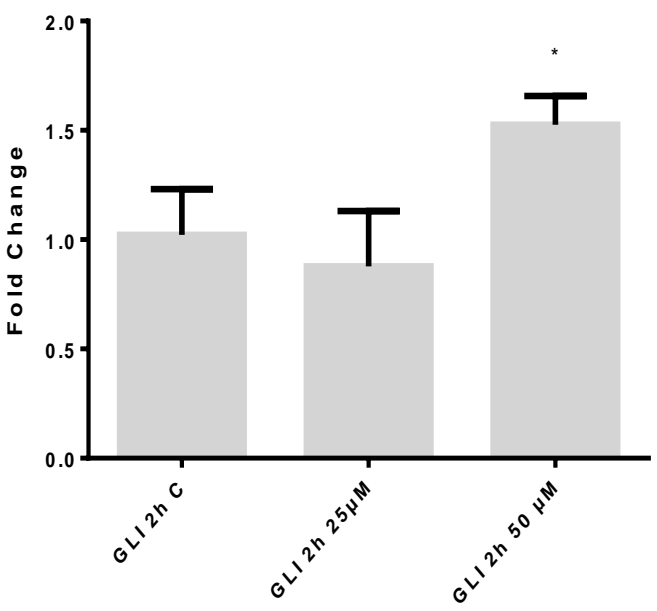

Figura 28. Acúmulo de transcritos de eg/1. Em (A): Bagaço de cana de açúcar, (B): Feno moído, (C) Farelo de trigo e em (D): Glicose. O Fold change foi calculado utilizando a condição controle de cada substrato e tempo. Asteriscos indicam diferença estatística em relação ao respectivo controle. $\left({ }^{*}\right) p<0,05 ;\left(^{* *}\right): p<0,01 ;\left(^{* * *}\right): p<0,001$.

Quando H. grisea foi cultivado em BCA (Fig. 28A), o tratamento com 5-AZA levou a uma queda no acúmulo de transcritos de eg/1 nos tempos de $2 \mathrm{~h}(25 \mu \mathrm{M})$ e $96 \mathrm{~h}(50 \mu \mathrm{M})$. Em Feno (Fig. 28B) e FT (Fig. 28C), uma redução destes transcritos também foi observada em $2 \mathrm{~h}$ (25 $\mu \mathrm{M})$. Já quando cultivado em glicose (Fig. 28D), repressor da expressão de genes do sistema celulolítico, um aumento do acúmulo de egl 1 foi verificado quando a droga estava presente na concentração de $50 \mu \mathrm{M}$. 
A

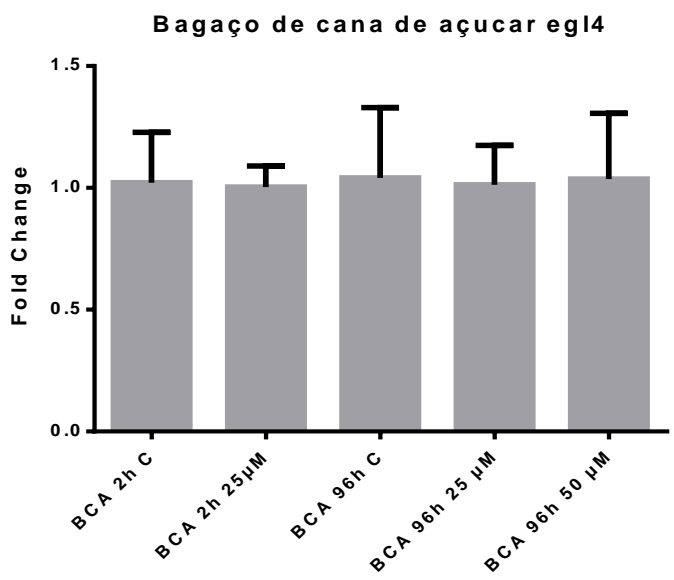

C

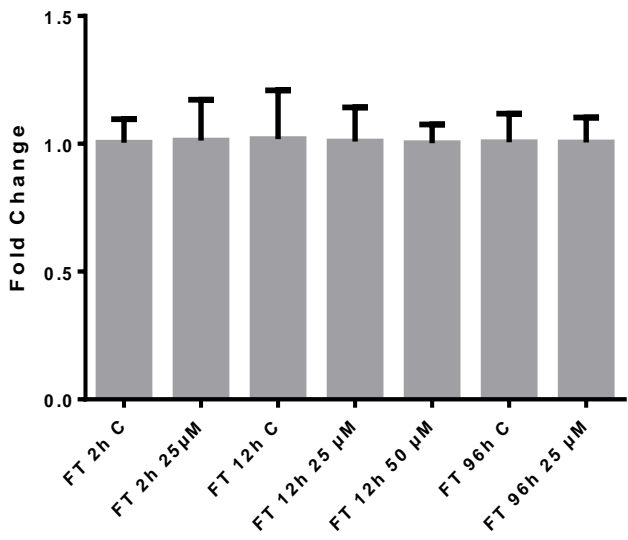

B

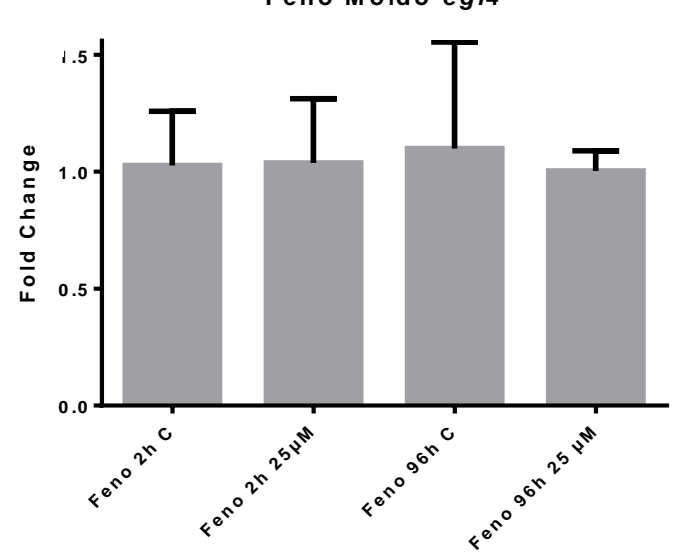

D

Glicose eg/4

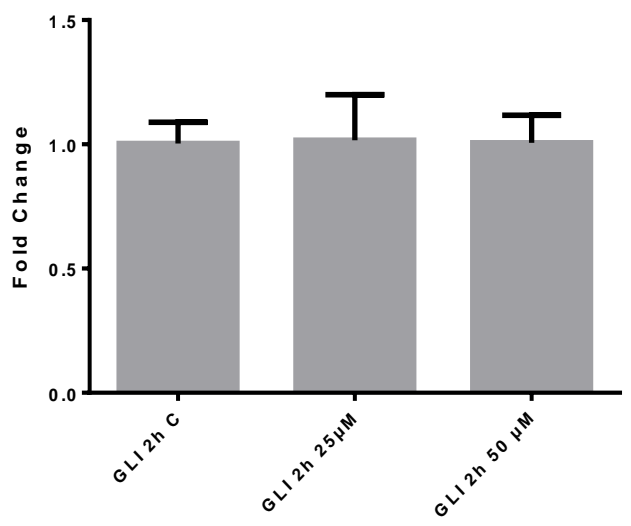

Figura 29. Acúmulo de transcritos de eg/4. Em (A): Bagaço de cana de açúcar, (B): Feno moído, (C) Farelo de trigo e em (D): Glicose. O Fold change foi calculado utilizando a condição controle de cada substrato e tempo. nd= não determinado

Para o gene eg/4, o perfil acúmulo de transcritos foi o mesmo para todos os substratos, tempos e concentrações da droga analisados, demonstrando que a fonte de carbono disponível e a presença da 5-AZA não afetaram esse acúmulo (Fig. 29). Mello-deSousa et al. (2011) analisaram, também por RT-qPCR, diversos genes do complexo celulolítico de $H$. grisea, sendo um dos alvos o gene eg/4. Nesse trabalho foi constado que, em pH alcalino $(\mathrm{pH}$ 8), o acúmulo de transcritos deste gene era muito baixo, não importando se a fonte de carbono para o fungo era glicose ou BCA. A partir desta informação, e levando em conta os achados de nosso trabalho, é plausível que egl4 não seja regulado pelo $\mathrm{pH}$, fonte de carbono ou pela metilação de DNA, sugerindo um mecanismo de regulação diferente daquele dos demais genes de endoglicanases de $H$. grisea (eg/1, eg/2, eg/3). Enquanto a maioria dos genes de celulases de H. grisea são regulados pelos fatores de transcrição CreA (repressão por glicose) e PacC (regulação pelo pH do meio externo), egl4 parece não ser, além disso a metilação do DNA também não parece ser o mecanismo que regula a expressão deste gene. Em uma dissertação de mestrado de nosso grupo (Angarten, 2013) foi analisada a região 
promotora de egl4 e foi verificado que, mesmo possuindo sítios de reconhecimento para CreA, esses levaram apenas à formação de complexos inespecíficos, reiterando que este fator de transcrição não parece estar envolvido na regulação de eg/4.

\subsection{Efeito da 5-AZA sobre o acúmulo de transcritos de genes de celobiohidrolases}

Também foram avaliados dois genes de celobiohidrolases: cbh1.1 (Fig. 30) e cbh1.2 (Fig. 31). Estes genes codificam, respectivamente, as enzimas $\mathrm{CBH} 1.1$ e $\mathrm{CBH} 1.2$, e são foco de estudos do nosso grupo há anos.

A

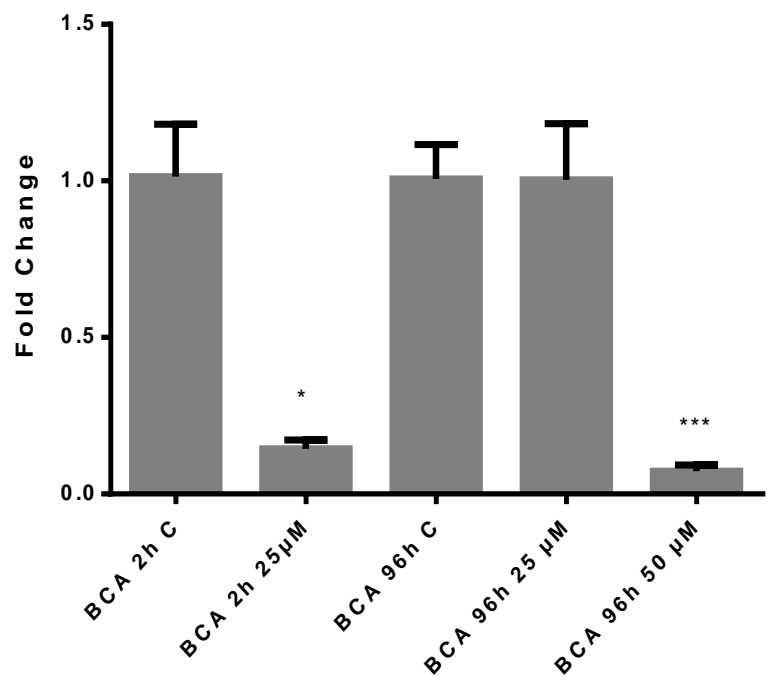

C

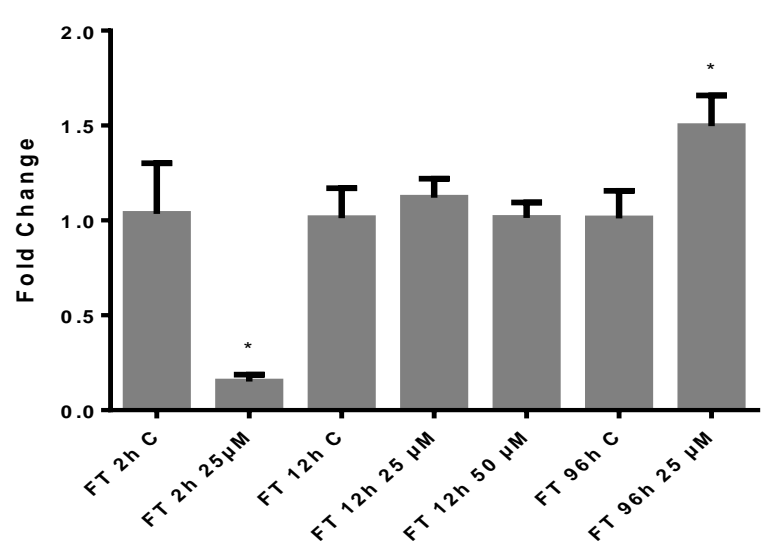

B

Feno Moído cbh1.1

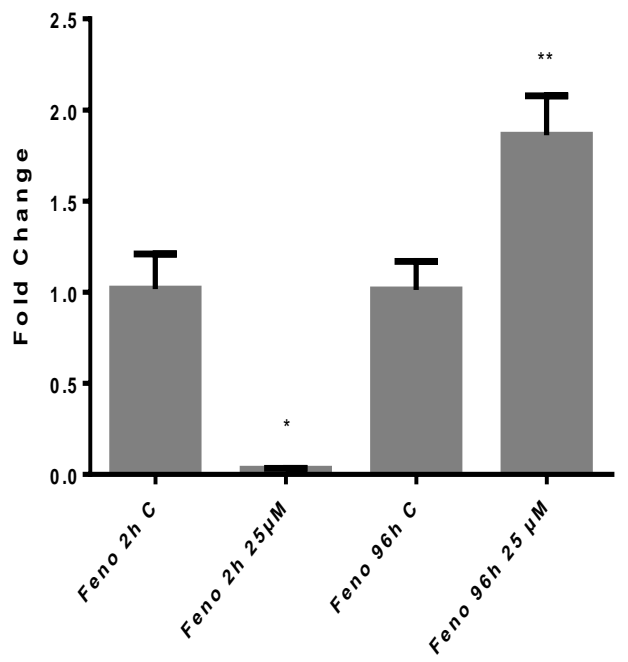

D

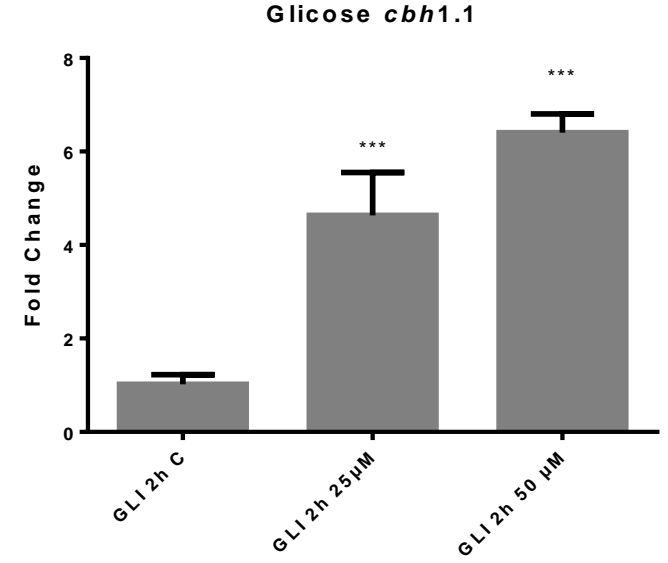

Figura 30. Acúmulo de transcritos de cbh1.1. Em (A): Bagaço de cana de açúcar, (B): Feno moído, (C) Farelo de trigo e em (D): Glicose. O Fold change foi calculado utilizando a condição controle de cada substrato e tempo. Asteriscos indicam diferença estatística em relação ao respectivo controle. $\left({ }^{*}\right) p<0,05 ;\left({ }^{* \star}\right): p<0,01 ;\left(^{* * \star}\right): p<0,001$ 
Para BCA (Fig. 30A), o perfil de acúmulo de transcrito de cbh1.1 demonstrou uma redução em 2 e em 96 h de tratamento com a 5-AZA. Para Feno (Fig. 30B) e FT (Fig. 30C), detectou-se uma redução de acúmulo de transcritos em $2 \mathrm{~h}$ de exposição à droga ( $25 \mu \mathrm{M})$ e um aumento em $96 \mathrm{~h}(25 \mu \mathrm{M})$. Em glicose (Fig. 30D), observou-se um aumento do acúmulo de transcritos cbh1.1 em ambas as concentrações de 5-AZA utilizadas, indicando que a desmetilação do DNA exerce efeito positivo sobre a regulação do gene.

A

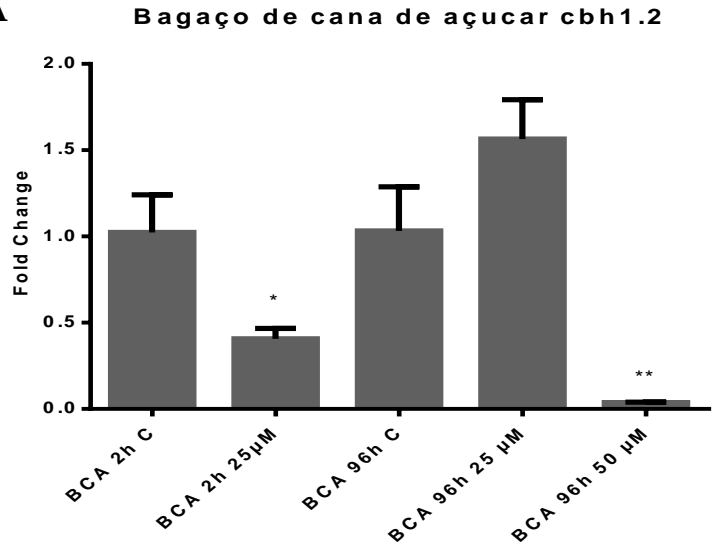

C

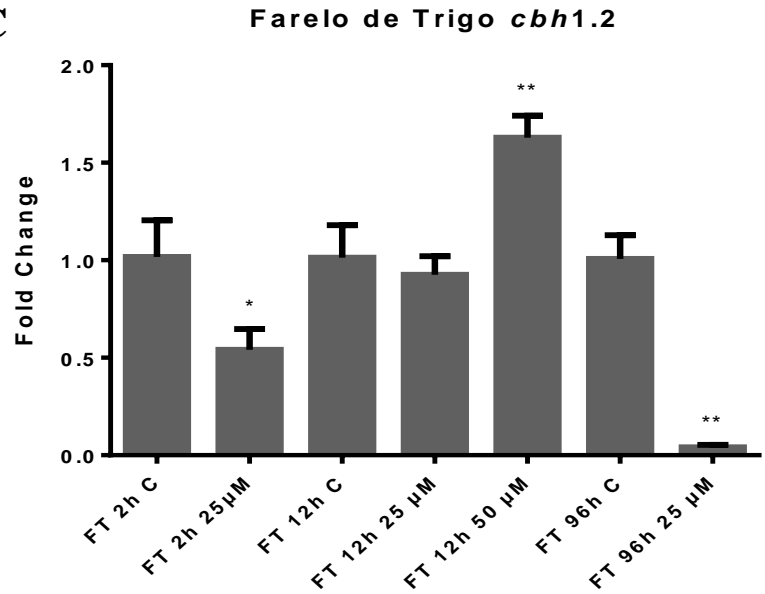

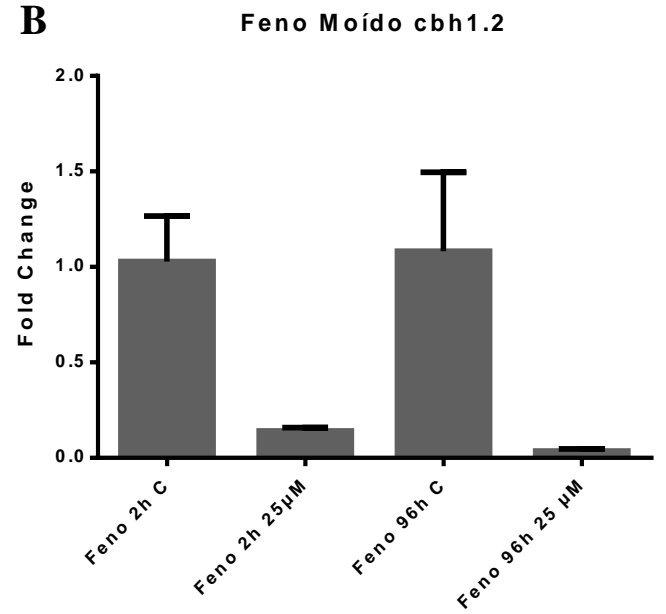

D

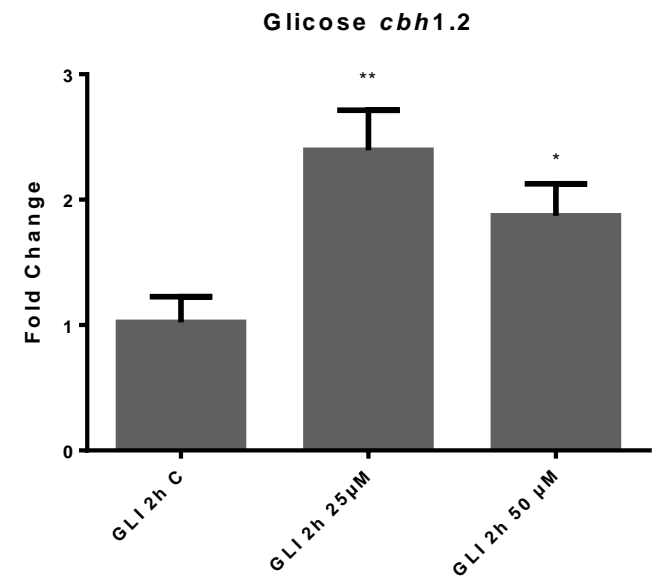

Figura 31. Acúmulo de transcritos de cbh1.2. Em (A): Bagaço de cana de açúcar, (B): Feno moído, (C) Farelo de trigo e em (D): Glicose. O Fold change foi calculado utilizando a condição controle de cada substrato e tempo. Asteriscos indicam diferença estatística em relação ao respectivo controle. $\left(^{*}\right) p<0,05 ;\left(^{* *}\right): p<0,01 ;\left(^{* \star *}\right): p<0,001$

Quando $H$. grisea foi crescido em BCA em presença de 5-AZA (Fig. 31A), uma redução do acúmulo de transcritos cbh1.2 foi observada em $2 \mathrm{~h}(25 \mu \mathrm{M})$ e $96 \mathrm{~h}(50 \mu \mathrm{M})$, porém um aumento foi detectado em $96 \mathrm{~h}$ na concentração de $25 \mu \mathrm{M}$, sendo que o mesmo não foi observado para o gene cbh1.1. Para Feno (Fig. 31B) e FT(Fig. 31C), ocorreu uma queda dos transcritos de $c b h 1.2$ quando a droga estava presente em $2 \mathrm{~h}$ de tratamento, e diferentemente de cbh1.1, uma redução destes transcritos também pode ser observada em $96 \mathrm{~h}(25 \mu \mathrm{M})$. Em 
glicose (Fig. 31D), assim como no caso de cbh1.1, quando a droga estava presente, independentemente da concentração, detectou-se um aumento de acúmulo de transcritos. Tais resultados indicam que, no tocante à metilação do DNA, o padrão de regulação de $c b h 1.1 \mathrm{e}$ cbh1.2 é diferente, como havia sido anteriormente demonstrado para a fonte de carbono e o $\mathrm{pH}$ do meio de cultura (Poças-Fonseca et al., 2000; Mello-de-Sousa et al., 2011).

\subsection{Efeito da 5-AZA sobre o acúmulo de transcritos do gene bg/4}

Os gráficos abaixo mostram o acúmulo de transcritos do gene bg/4 nas diferentes condições analisadas.

A

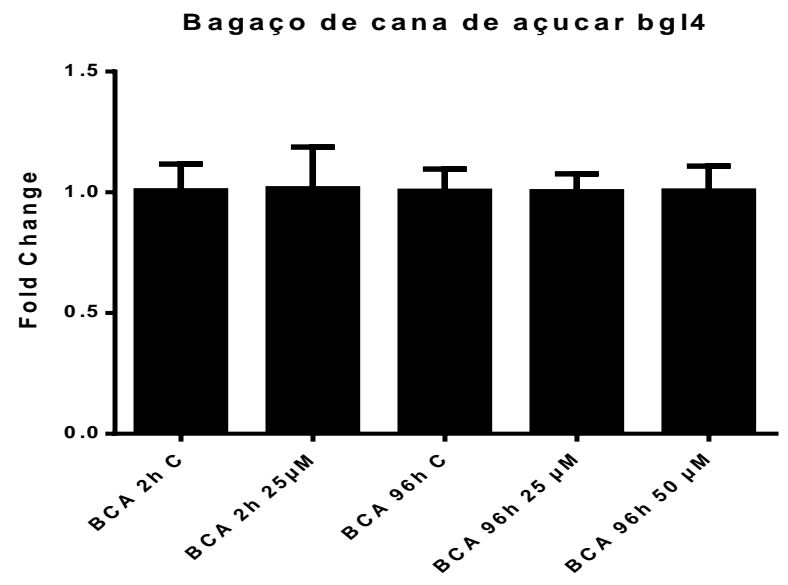

$\mathbf{C}$

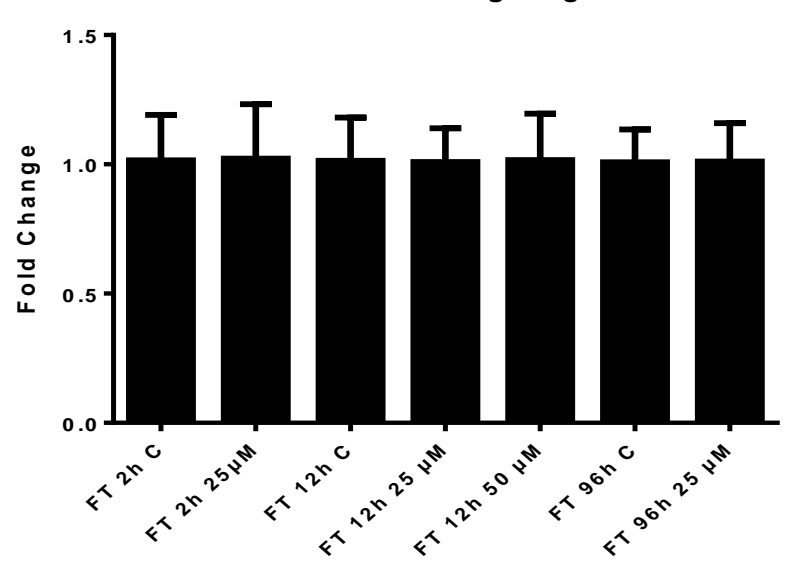

B

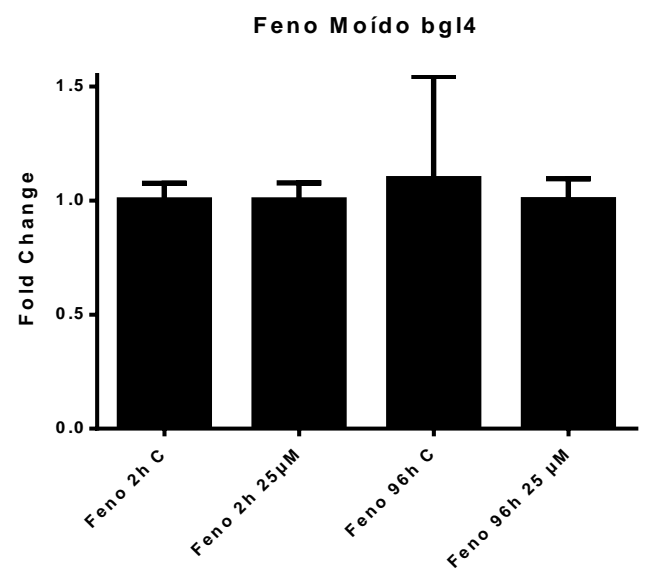

D

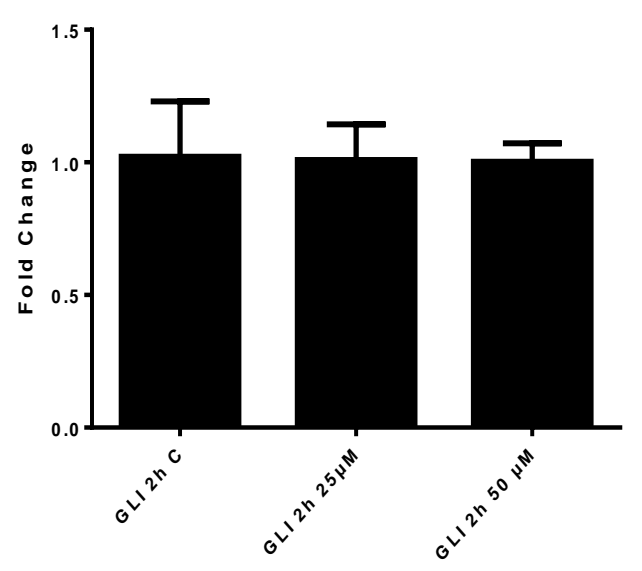

Figura 32. Acúmulo de transcritos de $b g / 4$. Em (A): Bagaço de cana de açúcar, (B): Feno moído, (C) Farelo de trigo e em (D): Glicose. O Fold change foi calculado utilizando a condição controle de cada substrato e tempo.

Para o gene de bg/4 (Fig. 31), não houve alteração de acúmulo de transcritos em nenhuma das condições analisadas, demostrando que a expressão desse gene não foi afetada 
pela fonte de carbono disponível e tampouco pelo tratamento com a 5-AZA. Curiosamente, a expressão do gene bg/4 mostrou-se induzida por BCA, em pH alcalino, no trabalho de Mellode-Sousa e colaboradores (2011). Benoliel e colaboradores (2010) expressaram o gene de bg/4 em S.cerevisiae e, em suas análises, verificaram que a atividade da proteína recombinante era tolerante a diferentes concentrações de glicose. Os dados de RT-qPCR apresentados aqui mostram que os níveis de transcritos de bg/4 permaneceram os mesmos quando o fungo foi cultivado em glicose, BCA, FT e feno, indicando que a presença de substratos complexos não induz a expressão deste gene em pH neutro. Tais dados são importantes para estratégias de otimização da produção e da atividade de beta-glicosidades do fungo $H$. grisea, que corresponde a um importante gargalo na conversão enzimática da lignocelulose.

\subsection{Efeito da 5-AZA sobre o acúmulo de transcritos de genes de endoxilanases}

Os genes utilizados para esta análise foram xyn1 (Fig. 33) e xyn2 (Figura 34).

A

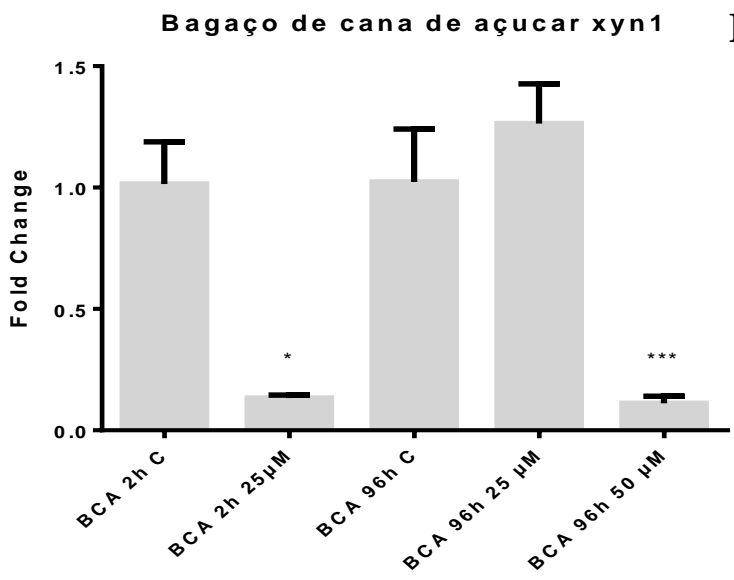

C

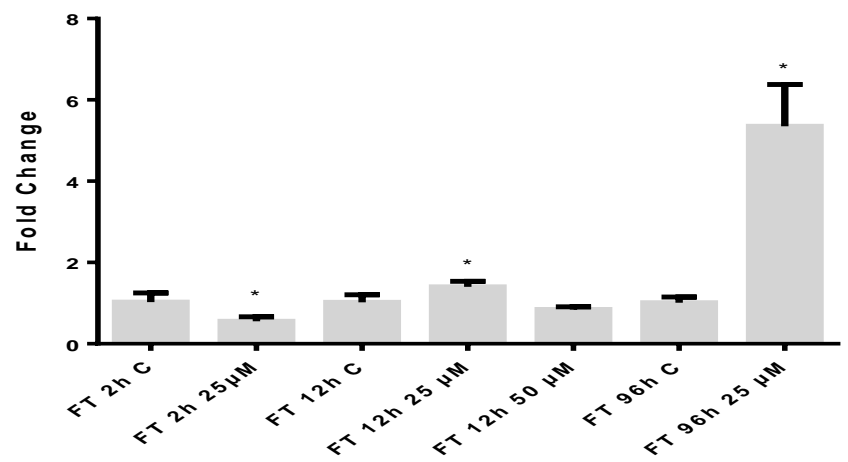

B

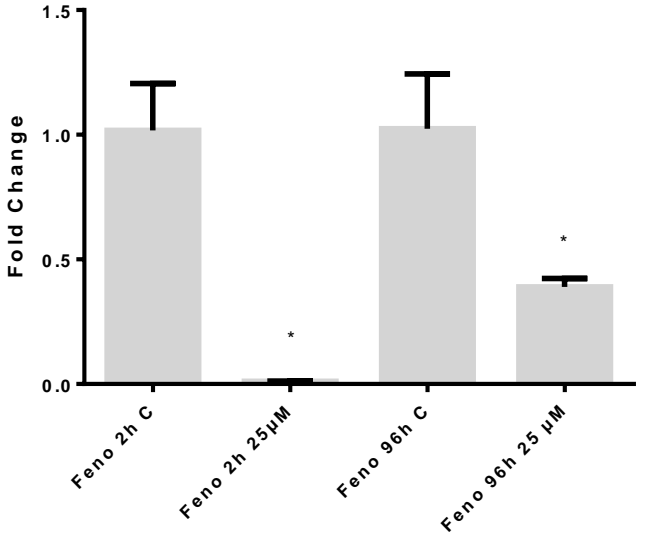

D

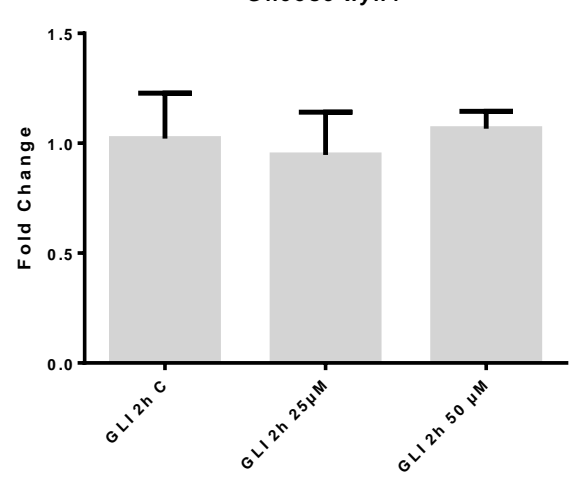

Figura 33. Acúmulo de transcritos de xyn1. Em (A): Bagaço de cana de açúcar, (B): Feno moído, (C) Farelo de trigo e em (D): Glicose. O Fold change foi calculado utilizando a condição controle de cada substrato e tempo. Asteriscos indicam diferença estatística em relação ao respectivo controle. $\left({ }^{*}\right) p<0,05 ;\left({ }^{* *}\right): p<0,01 ;\left(^{* * *}\right): p<0,001$. 
Para $x y n 1$, o tratamento com a droga levou a uma redução do acúmulo de transcritos quando em crescimento em BCA (Fig. 33A) e Feno (Fig. 33B), tanto em 2h (BCA e Feno) quanto em $96 \mathrm{~h}$ (BCA apenas na concentração de $50 \mu \mathrm{M}$ ) de cultivo. Já o Farelo de trigo, que apresenta um teor maior de hemicelulose do que de celulose (revisto em V. Menon, M. Rao, 2012), a presença de 5-AZA acarretou em uma redução de transcritos xyn1 apenas em $2 \mathrm{~h}$. Em $12 \mathrm{~h}$ e $96 \mathrm{~h}$, na concentração de $25 \mu \mathrm{M}$, verificou-se um aumento do acúmulo de transcritos de xyn1. Em glicose (Fig. 33D) não foi verificada alteração de acúmulo de xyn1 em nenhuma concentração analisada.

A
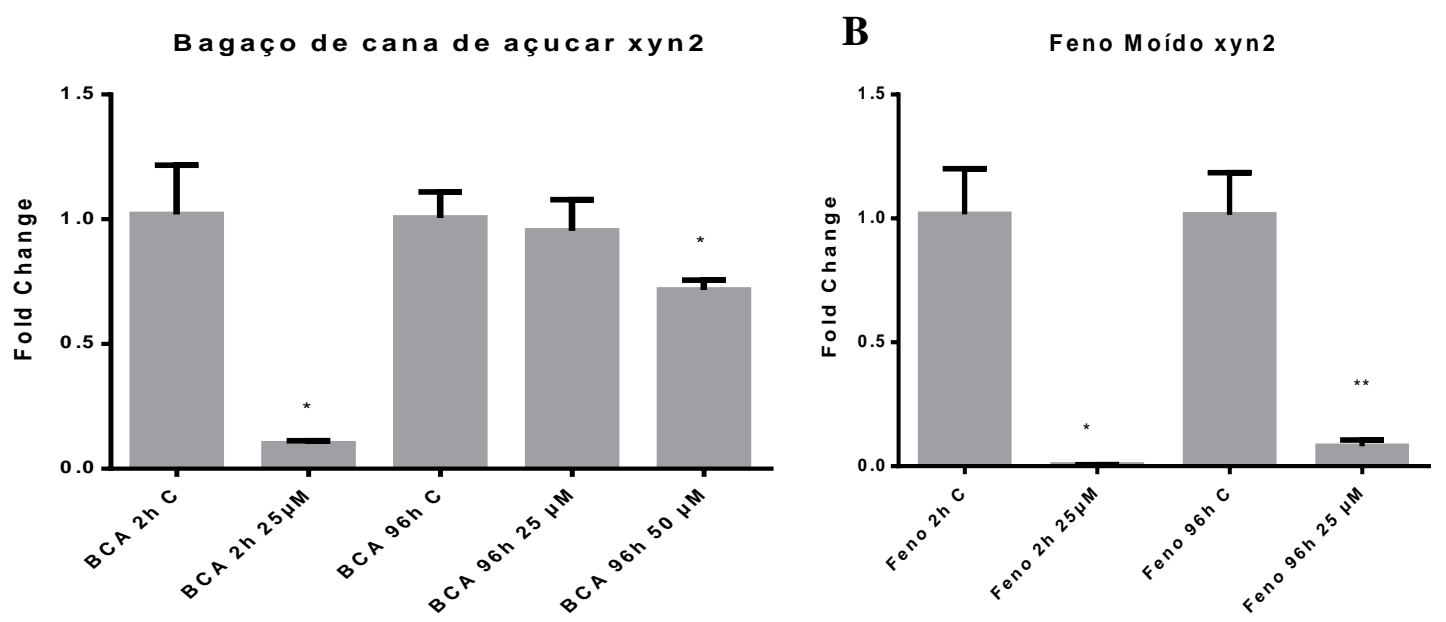

C

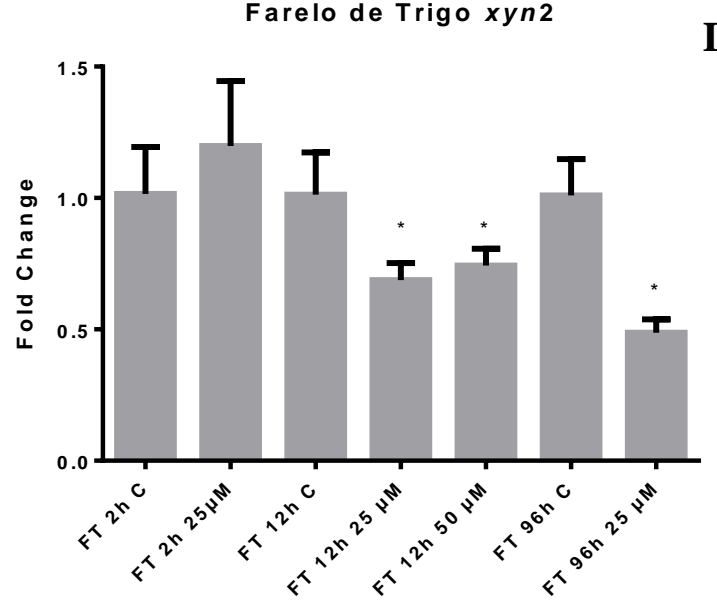

D

Glicose xyn2

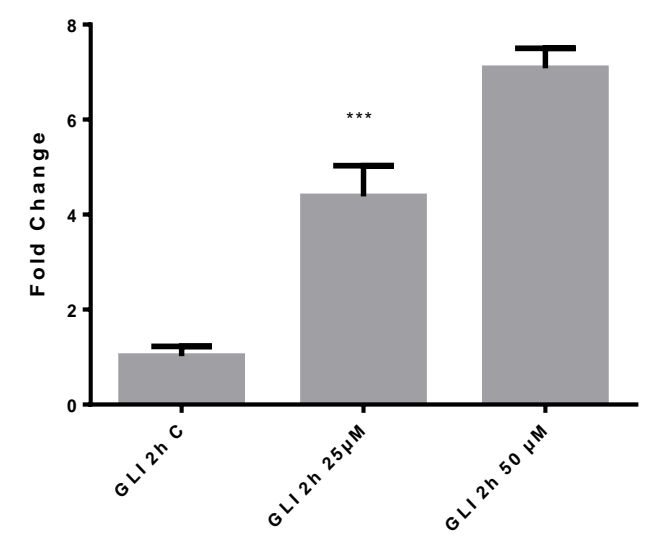

Figura 34. Acúmulo de transcritos de xyn2. Em (A): Bagaço de cana de açúcar, (B): Feno moído, (C) Farelo de trigo e em (D): Glicose. O Fold change foi calculado utilizando a condição controle de cada substrato e tempo. Asteriscos indicam diferença estatística em relação ao respectivo controle. $\left(^{*}\right) p<0,05 ;\left(^{* *}\right): p<0,01 ;\left(^{* * *}\right): p<0,001$

Quando o fungo $H$. grisea foi cultivado em BCA (Fig. 34A) e Feno (Fig. 34B), o perfil de acúmulo de transcritos de $x y n 2$ foi similar ao de $x y n 1$, sendo que uma redução foi observada nos tempos de 2 h e 96 h, nas mesmas concentrações que em relação a xyn1. Curiosamente, em reposta a crescimento em FT (Fig. 34C), estes genes apresentaram um perfil diferente e 
antagônico. Em 12 h de cultivo, xyn2 apresentou uma diminuição no acúmulo de transcritos para ambas as concentrações utilizadas, enquanto no mesmo tempo $x y n 1$ teve um aumento de transcritos quando a 5-AZA estava presente na concentração de $25 \mu \mathrm{M}$. O mesmo pode ser observado no tempo de $96 \mathrm{~h}$ : uma redução de xyn2 quando a droga estava presente e um aumento de xyn1 na mesma condição. Em glicose (Fig. 34D), o perfil de acúmulo de transcritos de xyn1 e xyn2 também foi diferente, uma vez que foi verificado um aumento significativo (superior a 4 vezes) do acúmulo de transcritos de xyn2 quando a droga estava presente, e este aumento ocorreu para ambas as concentrações utilizadas. likura e colaboradores (1997) descreveram o gene $x y n 1 H$. grisea, verificando que este gene apresenta na sua região promotora 3 sítios similares à sequência consenso para ligação do repressor catabólico (CREA ), uma indicação de que a transcrição desse gene seja reprimida pela presença de glicose no meio. Não dispomos de dados quanto à estrutura da região promotora de xyn2. Estes dados indicam que os genes de endoxilanases xyn1 e xyn2 do fungo $H$. grisea podem ser regulados por mecanismos diferentes, e que a metilação do DNA está envolvida nesta regulação.

Um importante achado em nosso trabalho foi que a desmetilação do DNA é capaz de superar a inibição que a glicose exerce sobre a transcrição dos genes de celulases e xilanase, informação de importante aplicação biotecnológica. Quando presente no meio, a glicose ativa o fator transcricional CreA, responsável pela repressão catabólica em organismos produtores de celulase e os genes dessas enzimas não são expressos. Porém, no presente trabalho foi verificado que, mesmo na presença da glicose como única fonte de carbono, quando $\mathrm{H}$. grisea foi cultivado em presença da droga 5-AZA por 2 horas, houve um aumento no acúmulo de transcritos de genes de celulases $c b h 1.1$, cbh1.2 e eg/1 e de xilanase xyn2. Além disso, foi observado um aumento da atividade de CMCase quando a droga estava presente durante 0 crescimento em glicose (Figura 22). O fato de esses genes terem aumentado a quantidade de transcritos em uma condição de repressão pode indicar que o sistema CreA esteja sendo afetado pela ação da droga ou que a regulação por metilação do DNA seja mais forte mecanisticamente do que a repressão por glicose.

\subsection{Correlação do efeito da 5-AZA nos ensaios enzimáticos e no acúmulo de transcritos dos diferentes genes analisados}

Os gráficos seguintes representam a correlação entre os valores de ensaios enzimáticos com os valores de Fold change obtidos nos experimentos de RT-qPCR. Nestes gráficos o intuito é verificar se existe uma relação do efeito da 5-AZA quando analisamos a atividade enzimática juntamente com o acúmulo de transcritos. Porém, é imprescindível lembrar que existem diferentes pontos de regulação entre o mRNA e a síntese e secreção de proteínas no sobrenadantes (a taxa de degradação do mRNA, os mecanismos de estabilização do mRNA, a taxa de tradução, as modificações pós-traducionais e as vias de secreção de proteínas). 


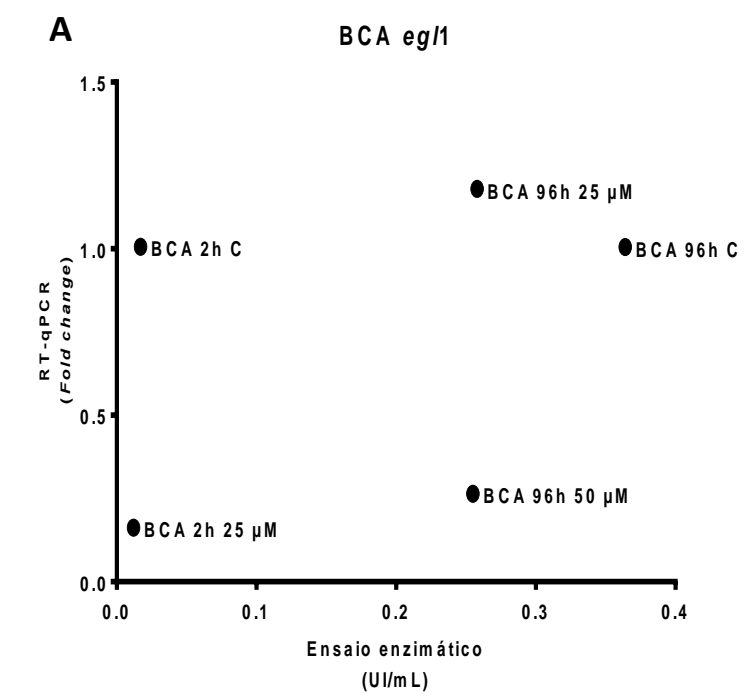

B Feno Moído egl1

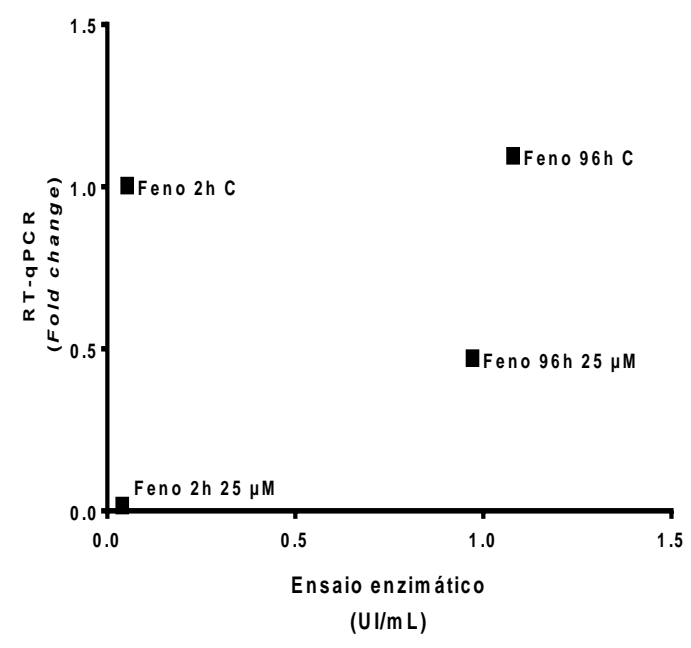

C

Farelo de Trigo eg/1
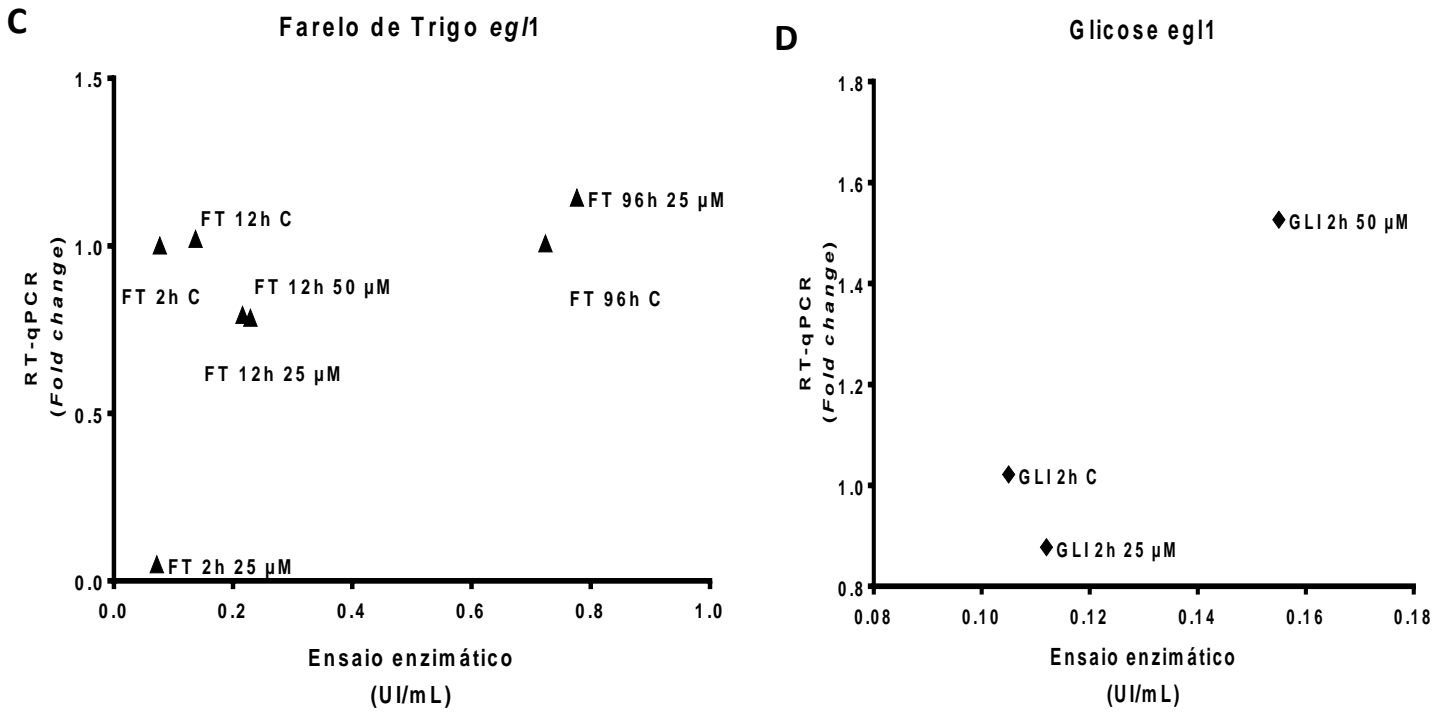

Figura 35. Correlação entre os valores de ensaios enzimáticos de CMCase com os de RTqPCR para o gene eg/1. Em (A): Bagaço de cana de açúcar, (B): Feno moído, (C) Farelo de trigo e em (D): Glicose.

A figura acima (Fig.35) mostra a correlação entre as atividades enzimáticas de CMCase detectadas nos sobrenadantes de cultura do fungo $\mathrm{H}$.grisea cultivado nos diferentes substratos e os valores de Fold change para o gene eg/1. Quando o fungo foi cultivado em BCA (Fig.35A) é possível detectar uma correlação positiva do efeito da 5-AZA entre o acúmulo de transcritos de eg/1 e o ensaio enzimático de CMCase em 96h de cultivo, já que a presença da droga na concentração de $50 \mu \mathrm{M}$ levou a uma redução tanto da atividade de CMCase quanto do acúmulo de transcritos deste gene quando o fungo foi cultivado neste substrato.

Quando o fungo foi cultivado em Feno Moído (Fig.35B) e em FT (Fig.35C) não foi possível verificar uma correlação do efeito da 5-AZA entre o ensaio enzimático de CMCase e o 
acúmulo de transcritos de eg/1. Para o cultivo em glicose (Fig.35D) é evidente uma correlação do efeito da 5-AZA entre atividade de CMCase e acúmulo de transcritos de eg/1. Quando a droga estava presente na concentração de $50 \mu \mathrm{M}$ e o fungo foi cultivado em glicose por $2 \mathrm{~h}$, foi possível verificar um aumento dos transcritos de eg/1 e também um aumento da atividade de CMCase, indicando uma possível correlação positiva. Vale lembrar que o aumento na atividade de CMCase detectado pode não ser reflexo do aumento de acúmulo de transcritos de eg/1, uma vez que, como já mencionado, existem diferentes vias regulatórias entre mRNA e enzimas secretadas, o que este gráfico mostra é que um aumento pode ser verificado tanto na atividade enzimática quanto no acúmulo de transcritos de eg/1 nesta condição.

A
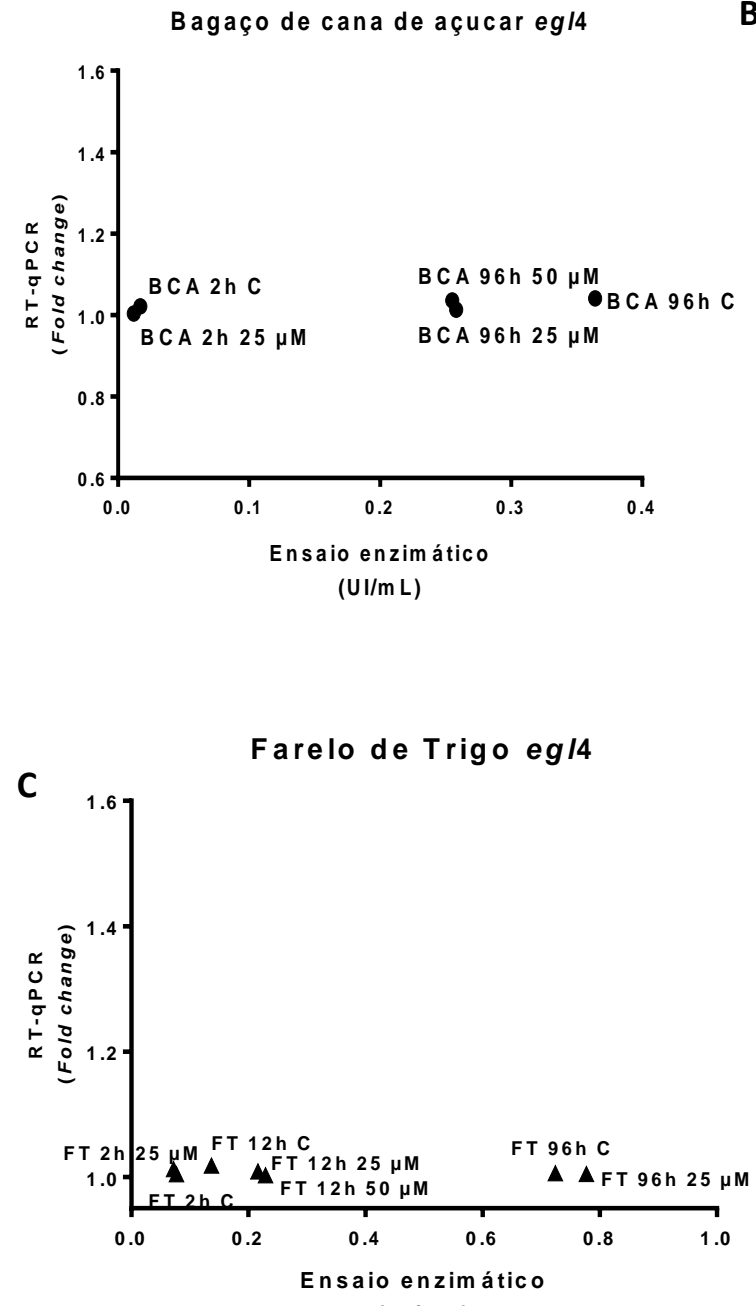

$(\mathrm{U} \mathrm{I} / \mathrm{mL})$
B Feno Moído eg/4

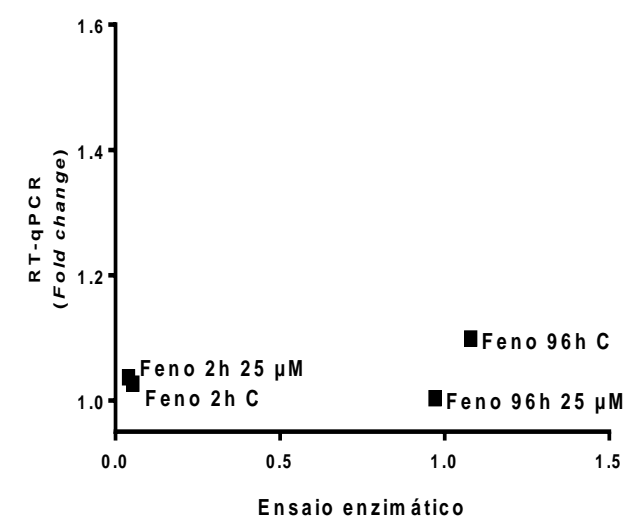

$(\mathrm{UI} / \mathrm{mL})$

D

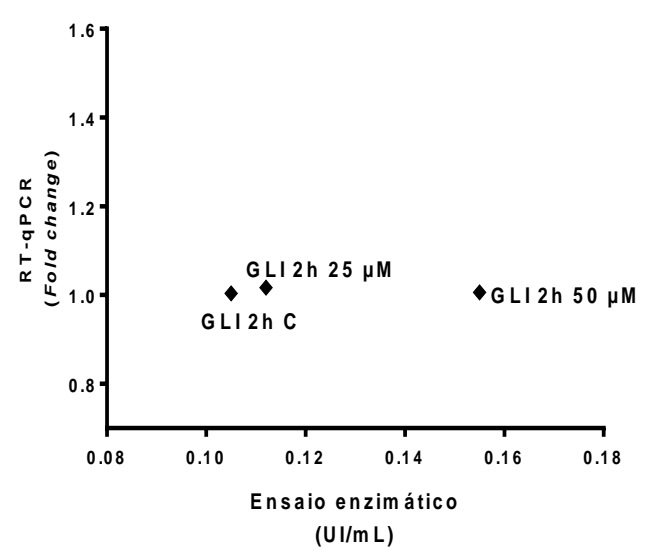

Figura 36. Correlação entre os valores de ensaios enzimáticos de CMCase com os de RTqPCR para o gene eg/4. Em (A): Bagaço de cana de açúcar, (B): Feno moído, (C) Farelo de trigo e em (D): Glicose.

Para o gene eg/4 (Fig.36) não foi possível verificar nenhuma correlação entre o acúmulo de transcritos e a atividade de CMCase, uma vez que os transcritos deste gene não foram afetados pelo substrato que o fungo foi cultivado ou pela presença da droga no meio de cultura (Fig.29). 
Neste trabalho não foram realizados ensaios enzimáticos para medir a atividade de celobiohidrolases, dessa forma realizar uma correlação entre ensaio enzimático e acúmulo de transcritos de celobiohidrolases seria inviável, porém a celobiodriolase $\mathrm{CBH} 1.2$, codificado pelo gene $c b h 1.2$, do fungo H.grisea foi descrita como possuindo atividade bi-funcional, isso é, apresentando tanto atividade de endoglicanase como de exoglicanase (Oliveira et al., 2013). Com isso, também foi realizada uma correlação entre atividade de CMCase e acúmulo de transcritos de cbh1.2.

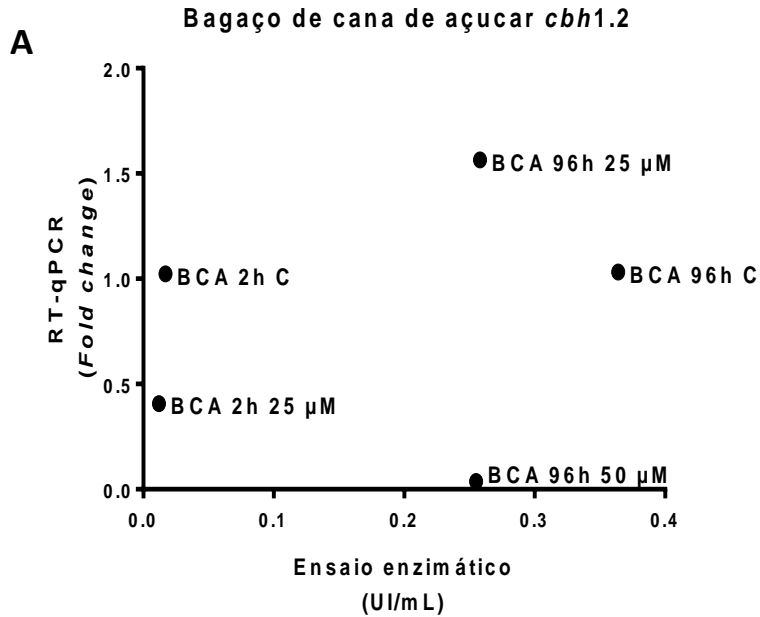

C

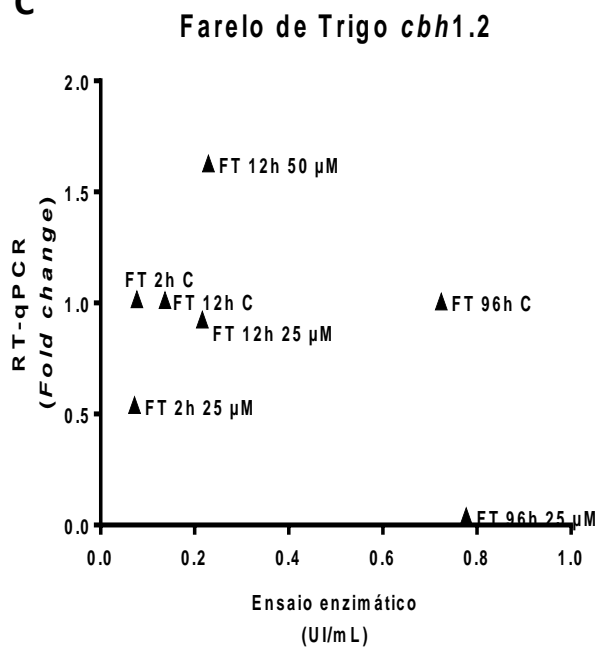

B

Feno Moído cbh1.2

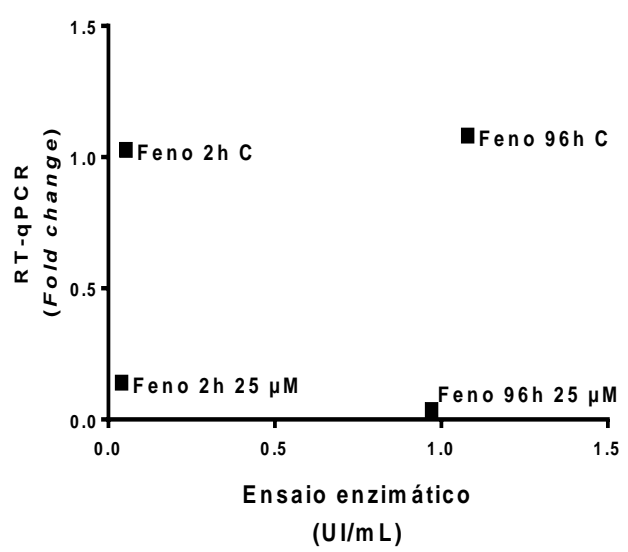

D

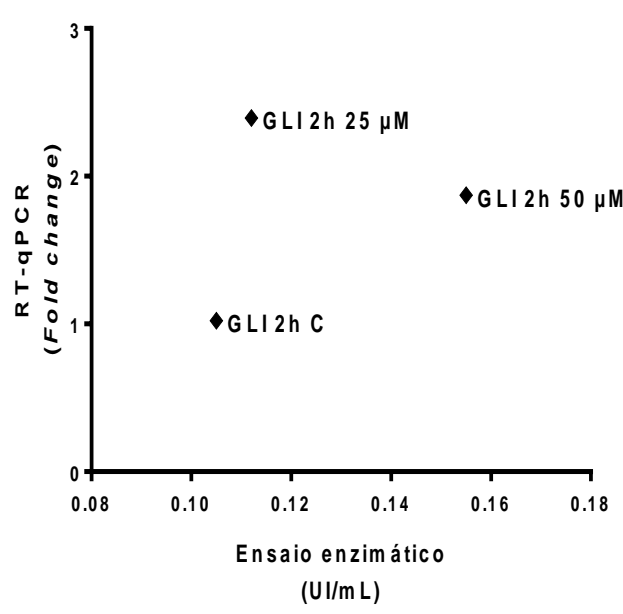

Figura 37. Correlação entre os valores de ensaios enzimáticos de CMCase com os de RTqPCR para o gene cbh1.2. Em (A): Bagaço de cana de açúcar, (B): Feno moído, (C) Farelo de trigo e em (D): Glicose.

Para o gene cbh1.2 foi possível verificar uma correlação do efeito da 5-AZA entre o acúmulo de transcritos e a atividade de CMCase detectada nos sobrenadantes de todos os substratos que o fungo foi cultivado. Para o cultivo em BCA (Fig.37A) a presença da droga na concentração de $50 \mu \mathrm{M}$ acarretou tanto na redução do acúmulo de transcritos do gene cbh1.2 
quanto na atividade de CMCase em $96 \mathrm{~h}$ de cultivo neste substrato. Quando o fungo foi cultivado em Feno Moído (Fig.37B) também foi possível verificar uma correlação do efeito da 5AZA em $96 \mathrm{~h}$, uma vez que a presença da droga na concentração de $25 \mu \mathrm{M}$ levou tanto a uma redução no acúmulo de transcritos deste gene quanto na atividade de CMCase. A Fig.37C mostra que uma relação do efeito da 5-AZA entre transcritos de cbh1.2 e atividade de CMCase também foi possível quando o fungo foi cultivado em FT. Em $12 \mathrm{~h}$ de cultivo neste substrato e na presença da 5-AZA na concentração de $50 \mu \mathrm{M}$ um aumento da atividade de CMCase e um aumento do acúmulo de transcritos de cbh1.2 foram detectados. Por fim, quando a glicose foi a única fonte de carbono para o fungo uma correlação do efeito da 5-AZA entre acúmulo de transcritos de cbh1.2 e atividade de CMCase também foi observada, já que quando a droga estava presente na concentração de $50 \mu \mathrm{M}$ foi verificado um aumento do acúmulo de transcritos do gene em questão e também na atividade de CMCase. É importante sempre ressaltar que essas diminuições/aumentos verificados na atividade enzimática de CMCase não são fruto da diminuição/aumento do acúmulo de transcritos de celulases, foi apenas verificado que para essas condições coincidentemente a droga teve o mesmo efeito sobre a atividade enzimática e o acúmulo de transcritos.

Não foi possível realizar uma análise de correlação entre a atividade enzimática com o acúmulo de transcritos dos genes cbh1.1 e bg/4, já que não foram realizados ensaios enzimáticos de celobiohidrolases e beta-glicosidases neste trabalho e ainda não foi demonstrado que estes genes de H.grisea produzam enzimas com atividade bi-funcional, como a CBH1.2. Dessa forma, não foram realizadas análises de correlação para estes dois genes.

Os próximos gráficos correlacionam o acúmulo de transcritos dos genes de xilanases analisados neste trabalho (xyn1 e xyn2) com a atividade de xilanase detectada nos sobrenadantes de cultura do fungo H.grisea cultivado nos diferentes resíduos agrícolas. 

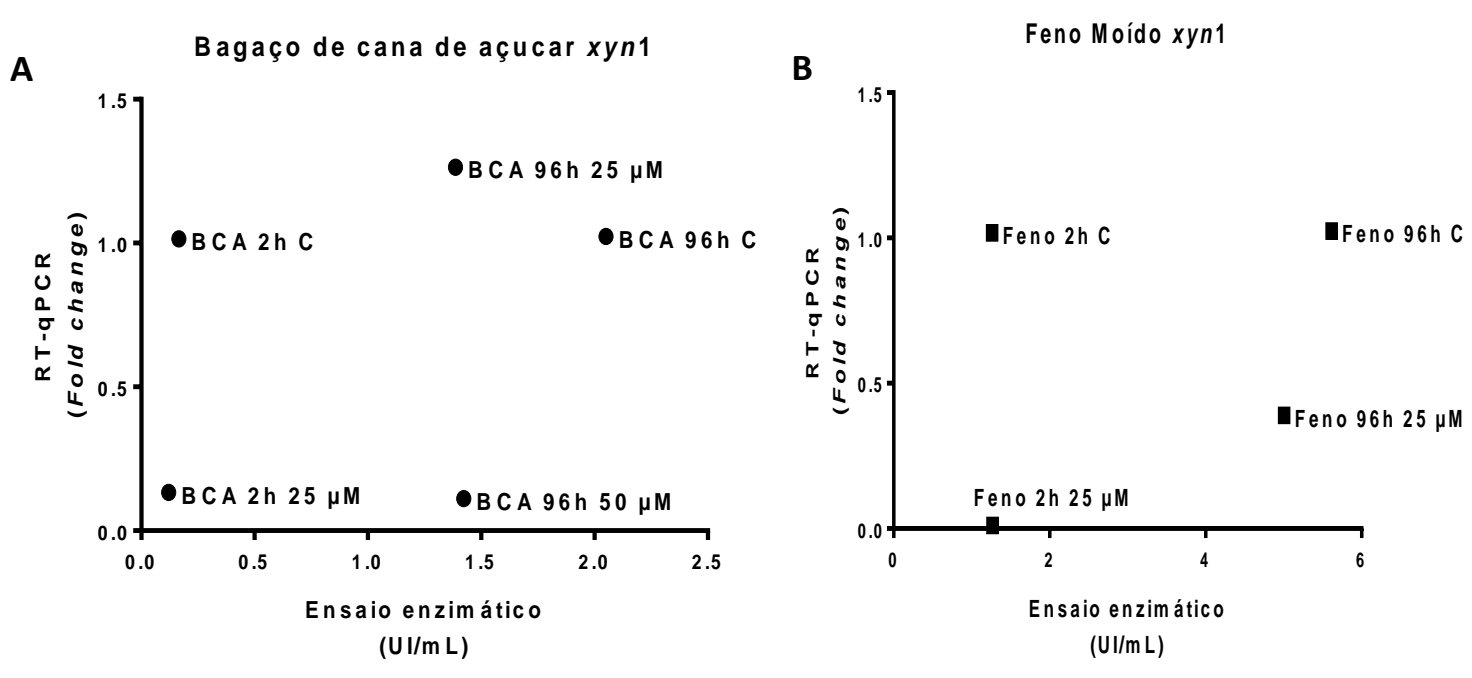

C

Farelo de Trigo xyn 1

D

Glicose $x y n 1$
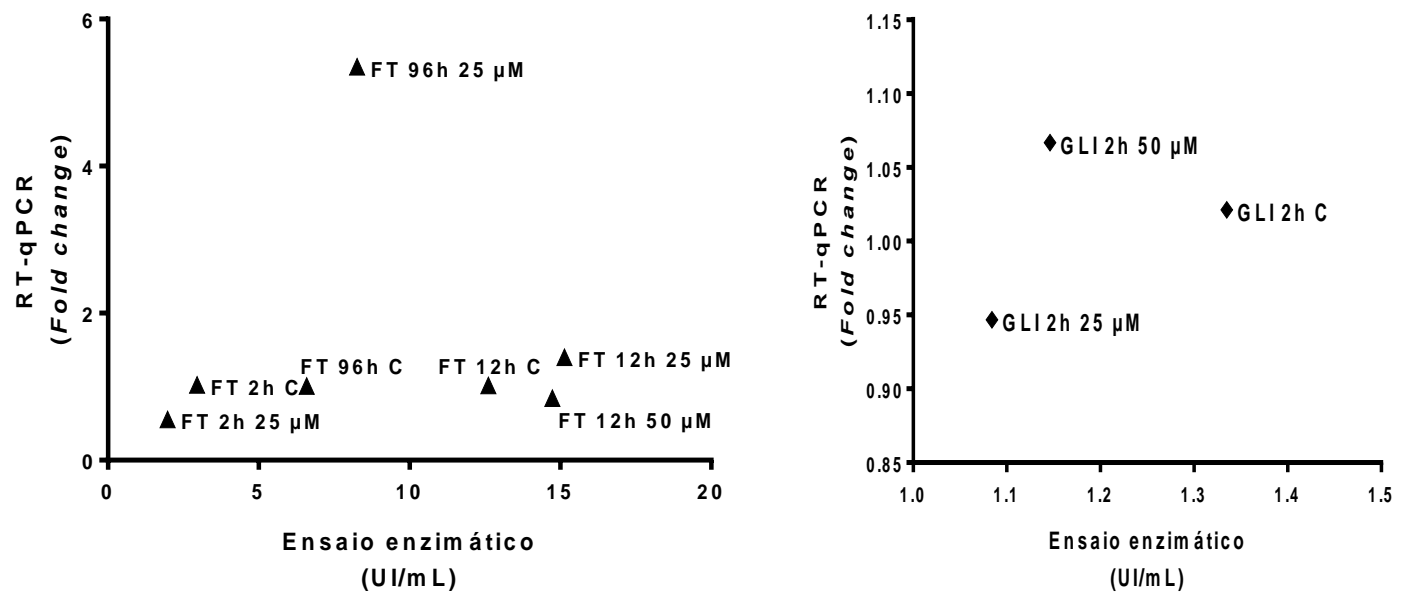

Figura 38. Correlação entre os valores de ensaios enzimáticos de xilanase com os de RTqPCR para o gene xyn1. Em (A): Bagaço de cana de açúcar, (B): Feno moído, (C) Farelo de trigo e em (D): Glicose.

Para o gene $x y n 1$ foi possível verificar uma correlação positiva do efeito da 5-AZA entre o acúmulo de transcritos deste gene e a atividade de xilanase para o cultivo do fungo em BCA (Fig.38A) e para FT (Fig.38C), mas nenhuma relação foi verificada para o Feno Moído (Fig.38B) e para GLI (Fig38D). Quando o fungo foi cultivado em BCA por $96 \mathrm{~h}$, a presença da droga 5-AZA na concentração de $50 \mu \mathrm{M}$ acarretou em uma redução da atividade de xilanase como também no acúmulo de transcritos do gene xyn1. Já quando o fungo foi cultivado em FT por 12 e 96 h, a 5-AZA levou a um aumento da atividade de xilanase e também do acúmulo de transcritos do gene xyn1 quando presente na concentração de $25 \mu \mathrm{M}$, indicando uma correlação positiva do efeito da droga neste substrato. O gene xyn2 não apresentou o mesmo 
perfil de $x y n 1$ quando foram correlacionadas a atividade de xilanase e o acúmulo de transcritos do gene xyn2 (Fig.39).

A

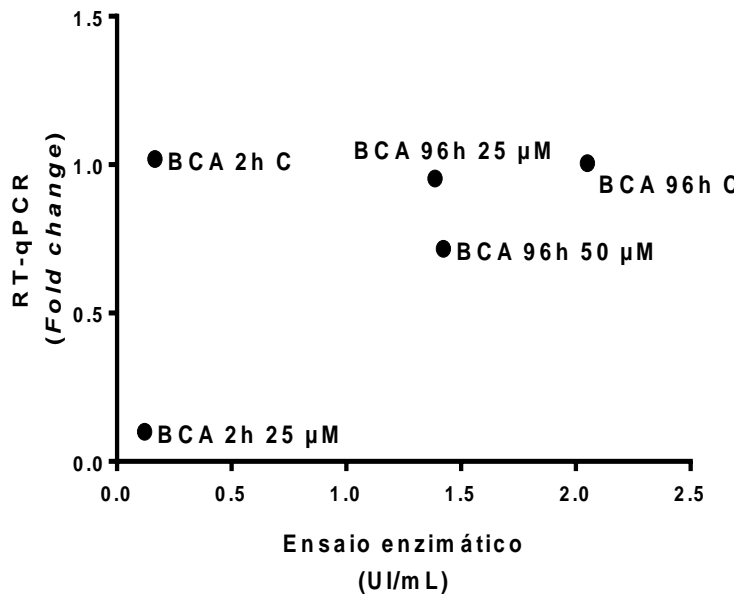

C

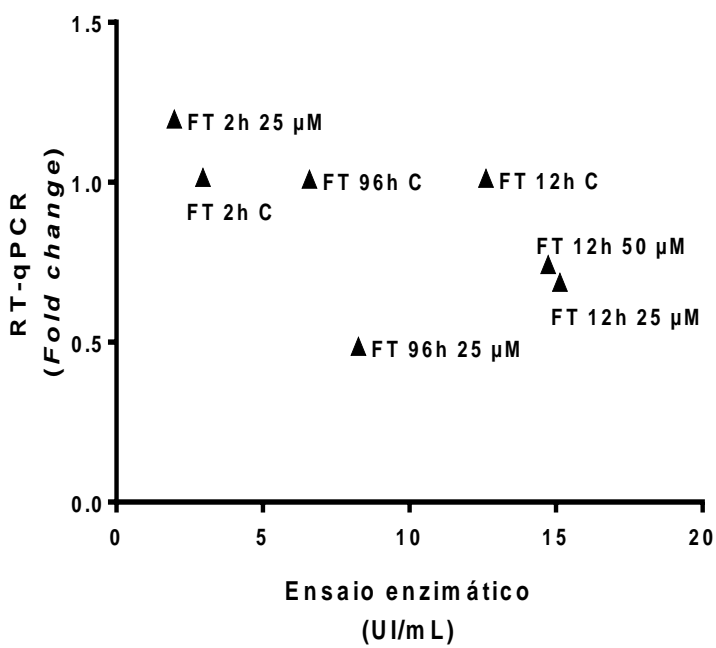

B Feno Moído xyn2

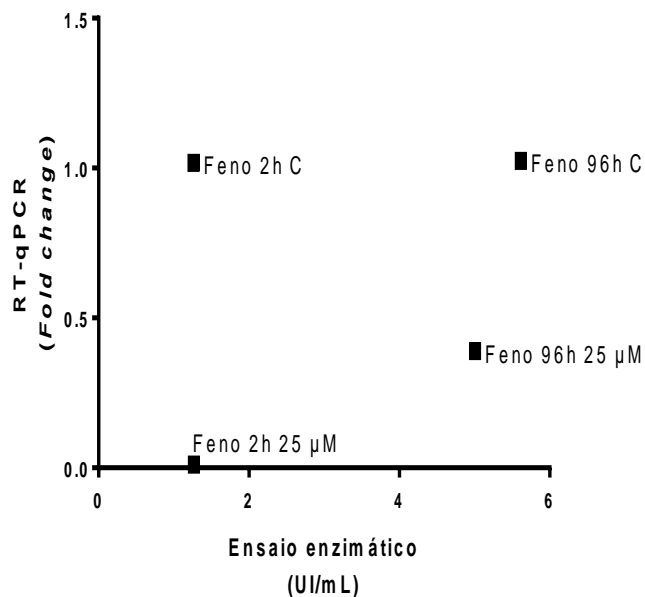

D Glicose $x y n 2$

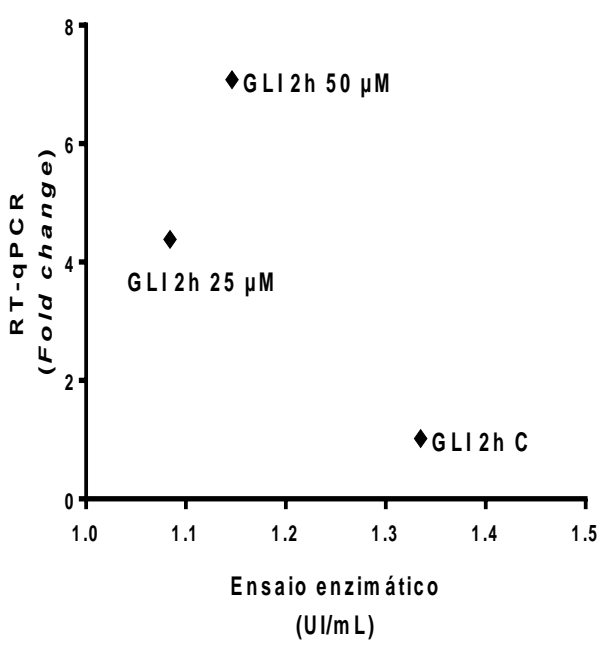

Figura 39. Correlação entre os valores de ensaios enzimáticos de xilanase com os de RTqPCR para o gene xyn2. Em (A): Bagaço de cana de açúcar, (B): Feno moído, (C) Farelo de trigo e em (D): Glicose.

Para o gene xyn2 foi possível verificar uma correlação do efeito da 5-AZA entre o acúmulo de transcritos e o ensaio enzimático de xilanase apenas quando o fungo foi cultivado em BCA por 96 h (Fig.39A), já que a presença da droga (na concentração de $50 \mu \mathrm{M}$ ) levou a uma redução da atividade de xilanase e a uma redução no acúmulo de transcritos do gene 
xyn2. Para o cultivo em Feno (Fig39.B), FT (Fig39.C) e GLI (Fig.39D) não foi verificada nenhuma correlação do efeito da 5-AZA entre acúmulo de transcritos do gene xyn2 e atividade de xilanase.

Analisando todos gráficos acima conjuntamente, fica evidente que a correlação do efeito da 5-AZA sobre os ensaios enzimáticos e os acúmulos de transcritos dos genes analisados não acontece para todos os substratos e tempos. Em alguns casos quando a droga estava presente foi possível verificar um aumento/diminuição da atividade enzimática e também um aumento/diminuição de um gene que codifica uma enzima com atividade enzimática relacionada, porém isso nem sempre é verdade. A justificativa para ocorrer esta diferença está nos diversos mecanismos regulatórios que existem entre a transcrição do mRNA e a produção e secreção da enzima. Dessa forma, é coerente não exista sempre uma relação positiva entre acúmulo de transcritos e ensaio enzimático. 


\section{CONCLUSÃO E PERSPECTIVAS}


Nesse trabalho foram avaliados os efeitos da droga 5-aza-2'-deoxi-citidina sobre as atividades enzimáticas de CMCase e de xilanase do fungo termofílico $\mathrm{H}$. grisea var. thermoidea e no acúmulo de transcritos de genes de celulases e xilanases. Para isso, o fungo foi cultivado em 4 diferentes substratos: bagaço de cana-de-açúcar explodido a vapor (BCA), farelo de trigo (FT), feno moído e glicose por 2, 12 e 96 horas na presença de duas concentrações diferentes da droga 5-AZA , $25 \mu \mathrm{M}$ e $50 \mu \mathrm{M}$.

Em presença de 5-AZA, a atividade de CMCase secretada quando do cultivo em BCA e feno manteve-se inalterada em 2 e 12 h, porém diminui em $96 \mathrm{~h}$. Em FT e glicose, um aumento de atividade foi detectado para $12 \mathrm{~h}$ de cultivo em presença de 5-AZA $50 \mu \mathrm{M}$, enquanto para as demais condições não houve modificação em relação aos controles.

A presença de 5-AZA em cultivo em BCA levou a uma diminuição da atividade de xilanase total em $96 \mathrm{~h}$; essa atividade não foi afetada nos períodos de incubação menores. Para a atividade de xilanase induzida por crescimento em feno ou em glicose, nenhuma alteração foi observada. Em FT, a 5-AZA provocou as mais notáveis alterações na atividade xilanolítica dos sobrenadantes: diminuição em 2 h/50 $\mu \mathrm{M}$ porém aumento em 12 e 96 h/25 $\mu \mathrm{M}$.

Quanto ao acúmulo de transcritos, distintos perfis foram observados para os diferentes genes em presença de 5-AZA:

- eg/1 teve o acúmulo diminuído em BCA 2 h/25 $\mu \mathrm{M}$ e 96 h/50 $\mu \mathrm{M}$, feno moído $2 \mathrm{~h} / 25 \mu \mathrm{M}$ e em FT $2 \mathrm{~h} / 25 \mu \mathrm{M}$.

- cbh1.1 teve os transcritos diminuídos em BCA 2 h/25 $\mu \mathrm{M}$ e $96 \mathrm{~h} / 25 \mu \mathrm{M}$, Feno e FT $2 \mathrm{~h} / 25 \mu \mathrm{M}$, porém aumentados nesses dois últimos substratos em $96 \mathrm{~h} / 25 \mu \mathrm{M}$.

- cbh1.2 teve o acúmulo de transcritos diminuído em BCA 2 h/25 $\mu \mathrm{M}$ e 96 h/50 $\mu \mathrm{M}$; para Feno e FT, uma redução ocorreu em 2 h/25 $\mu \mathrm{M}$ e 96/h $25 \mu \mathrm{M}$. Aumento do acúmulo de transcritos para esse gene foi detectado em BCA 96 h/25 $\mu \mathrm{M}$ e FT 12 h/50 $\mu \mathrm{M}$.

- Para xyn1 se observou redução do acúmulo de transcritos em BCA 2 h/25 $\mu \mathrm{M}$ e $96 \mathrm{~h} / 50 \mu \mathrm{M}$, Feno $2 \mathrm{~h} / 25 \mu \mathrm{M}$ e $96 \mathrm{~h} / 25 \mu \mathrm{M}$ e FT $2 \mathrm{~h} / 25 \mu \mathrm{M}$. Por outro lado, houve aumento dos transcritos em FT $12 \mathrm{~h} / 25 \mu \mathrm{M}$ e $96 \mathrm{~h} / 25 \mu \mathrm{M}$.

- Para os transcritos de xyn2, redução foi observada em BCA 2 h/25 $\mu \mathrm{M}$ e 96 $\mathrm{h} / 50 \mu \mathrm{M}$, Feno $2 \mathrm{~h} / 25 \mu \mathrm{M}$ e $96 \mathrm{~h} / 25 \mu \mathrm{M}$ e em FT $12 \mathrm{~h} / 25 \mu \mathrm{M}, \mathrm{FT} 12 \mathrm{~h} / 50 \mu \mathrm{M}$ e $96 \mathrm{~h} / 25$ $\mu \mathrm{M}$.

- A presença da 5-AZA mostrou-se capaz de superar a repressão por glicose e aumentar os níveis dos transcritos eg/1, cbh1.1, cbh1.2 e xyn2 quando o fungo foi crescido nesse substrato como única fonte de carbono. 
- Os níveis de transcritos dos genes eg/4 e bg/4 não sofreram alteração em nenhuma das condições estudadas.

Os dados do presente trabalho indicam que a modulação epigenética, no nível de metilação do DNA, exerce papel na regulação da expressão dos genes de celulase e xilanase do fungo termofílico $H$. grisea var. thermoidea e que pode ser empregada visando à otimização de processos biotecnológicos de conversão de resíduos agrícolas em produtos de maior valor agregado. 
REFERÊNCIAS BIBLIOGRÁFICAS 
Abraham, A.-L., Nagarajan, M. et al. (2012). Genetic Modifiers of Chromatin Acetylation Antagonize the Reprogramming of Epi-Polymorphisms. PLOS Genetics 8(9): 1-16e10029581.

ABREU, D., MORAES, L. A., NASCIMENTO, E. N., OLIVEIRA, R. A. A Produção de Cana-deaçúcar no Brasil e a Saúde de Trabalhador Rural. Revista Brasileira de Medicina do Trabalho. Ed. 9(2), 2011, p. 49-61.

Aghcheh R.K. \& Kubicek C.P. Epigenetics as an emerging tool for improvement of fungal strains in biotechnology. Appl Microbiol Biotechnol(2015). DOI: 10.1007/s00253-015-6763-2.

Angarten, N.B. O (2013). Análise estrutural dos promotores dos genes de endoglicanase eg/1 e eg/4 de Humicola grisea var. thermoidea. Dissertação de Mestrado apresentada ao Departamento de Biologia Celular da Universidade de Brasília

Aramayo R, Selker EU. 2013. Neurospora crassa, a Model System for Epigenetics Research. Cold Spring Harbor Perspectives in Biology 5: a017921-a017921.

ARAÚJO, E.F.; BARROS, E.G.; CALDAS, R.A. \& SILVA, D.O. $\beta$-glucosidase activity of a thermophilic cellulolytic fungus Humicola sp. Biotechnol. Lett., 5: 781- 784. 1983.

Aro, N.; Pakula, T.; Penttila, M. (2005).Transcriptional regulation of plant cell wall degradation by filamentous fungi. FEMS Microbiol Rev, v. 29, n. 4, p. 719-39.

ARO, N.; SALOHEIMO, A.; ILMÉN, M. \& PENTTILÄ, M. ACEIl, a novel transcriptional activator involved in regulation of cellulase and xylanase genes of Trichoderma reesei. J. Biol. Chem., 276: 24309-24314. 2001.

Azevedo M de, O., M. S. Felipe, et al. (1990). "Cloning, sequencing and homologies of the cbh1 (exoglucanase) gene of Humicola grisea var. thermoidea." J Gen Microbiol 136(12): 2569-76.

Bae, H. J., Kim, H. J., Kim, Y. S. (2008) Production of a recombinant xylanase in plants and its potential for pulp biobleaching applications. Bioresource Technology, 99:3513-3519.

Baitey, C. and Arst, H. N., 1975. Carbon catabolite repression in Aspergillus nidulans. Eur. J. Biochem., 51: 573-577.

Beguin, P. and J. P. Aubert (1994). "The biological degradation of cellulose." FEMS Microbiol Rev 13(1): 25-58.

Benoliel, B., Pocas-Fonseca, M. J., Goncalves, F. A., \& Pepe, L. M. (2010). Expression of a Glucose tolerant $\beta$-glucosidase from Humicola grisea var. thermoidea in Saccharomyces cerevisiae. Appl Biochem Biotechnol , 160, 2036-2044.

Bjanesoy T.E.et al. Altered DNA methylation profile in Norwegian patients with Autoimmune Addison's Disease. Molecular Immunology 59:208-216(2014). 
Brenachot, X. et al (2014). The histone acetyltransferase MOF activates hypothalamic polysialylation to prevent diet-induced obesity in mice. Molecular metabolism 3: 619-629.

Brosch G., Loidl P., Graessle S. (2008). Histone modifications and chromatin dynamics: a focus on filamentous fungi. FEMS Microbiol. Rev. 32, 409-439. 10.1111/j.1574-6976.2007.00100.x

Burgers, W. A., Fuks, F. \& Kouzarides, T. (2002). DNA methyltransferases get connected to chromatin. Trends in Genetics 18(6):275-277.

Caddick, M. X.; Brownlee, A. G.; Arst, H. N., Jr. (1986).Regulation of gene expression by pH of the growth medium in Aspergillus nidulans. Mol Gen Genet, v. 203, n. 2, p. 346-53.

Calcagno-Pizarelli, A. M., Negrete-Urtasun, S., Denison, S. H., Rudnicka, J. D., Bussink, H.-J., Munera-Huertas, T., et al. (2007). Establishment of the ambient pH signaling complex in Aspergillus nidulans: Pall assists plasma membrane localization of PalH. Eukaryot Cell , 6 (12), 2365-2375.

CARDELLO, L.; TERENZI, H.F. \& JORGE, J.A. A cytosolic trehalase from the thermophilic fungus Humicola grisea var. thermoidea. Microbiology, 140: 1671-1677.1994.

Champagne, F. A. (2013). Epigenetics and developmental plasticity across species. Dev. Psychobiol. 55, 33-41. doi: 10.1002/dev.21036

CHAVES, V.M.G. Algumas características fisiológicas e propriedades do complexo celulase de um fungo termófilo isolado de compostagem. Dissertação (Mestrado), Universidade Federal de Viçosa-MG. 1982.

Chen PY, Montanini B, LiaoWW, Morselli M, Jaroszewicz A, Lopez D, Ottonello S, Pellegrini MA (2014) Comprehensive resource of genomic, epigenomic and transcriptomic sequencing data for the black truffle Tuber melanosporum. Gigascience 3:25. doi:10.1186/2047-217X-3-25

Chulkin, A. M., Vavilova, E. A., and Benevolenskij, S. V.: Transcriptional regulator of carbon catabolite repression CreA of filamentous fungus Penicillium canescens, Mol. Biol., 44, 596-605 (2010).

Collins T., Gerday C., Feller G. (2005). Xylanases, xylanase families and extremophilic xylanases.FEMS Microbiol. Rev. 29, 3-23.10.1016/j.femsre.2004.06.005

Cosgrove D. J. (2005). Growth of the plant cell wall. Nat. Rev. Mol. Cell Biol. 6, 850-861 $10.1038 / \mathrm{nrm} 1746$.

Crucello A, Sforça DA, Horta MAC, dos Santos CA, Viana AJC, Beloti LL, et al. (2015) Analysis of Genomic Regions of Trichoderma harzianum IOC-3844 Related to Biomass Degradation. PLoS ONE 10(4): e0122122. doi:10.1371/journal.pone.0122122 
Cubero, B.; Scazzocchio, C. (1994).Two different, adjacent and divergent zinc finger binding sites are necessary for CREA-mediated carbon catabolite repression in the proline gene cluster of Aspergillus nidulans. EMBO J, v. 13, n. 2, p. 407-15.

Da Silva, R.; Yim, D. K.; Park, Y. K. (1994).Application of thermostable xylanases from Humicola sp. for pulp improvement. Journal of Fermentation and Bioengineering, v. 77, n. 1, p. 109-111.

Dang, Y.; Li, L.; Guo, W.; Xue, Z.; Liu, Y. Convergent transcription induces dynamics DNA methylation at disiRNA loci. PLoS Genet. 2013, 9, e1003761.

Dashtban M, Schraft H, Qin W: Fungal bioconversion of lignocellulosic residues; opportunities \& perspectives. Int J Biol Sci 2009, 5:578-595.

Davis, D. (2003). Adaptation to environmental pH in Candida albicans and its relation to pathogenesis. Curr Genet , 44 (1), 1-7.

De Faria, F. P., O. V. Te, et al. (2002). "Expression and processing of a major xylanase (XYN2) from the thermophilic fungus Humicola grisea var. thermoidea in Trichoderma reesei." Lett Appl Microbiol 34(2): 119-23.

DE PAULA, E.H.; POÇAS-FONSECA, M.J. \& AZEVEDO, M.O. The product of Humicola grisea var. thermoidea $c b h 1.2$ gene is the major protein under induction by lignocellulosic residues. World Journal of Microbiology \& Biotechology, 19: 631-635. 2003.

De-Paula, E. H., L. P. Ramos, et al. (1999). "The potential of Humicola grisea var. thermoidea for bioconversion of sugar cane bagasse." Bioresource Technology 68(1): 35-41.

Diez, E., Alvaro, J., Espeso, E. A., Rainbow, L., Suarez, T., Tilburn, J., et al. (2002). Activation of the Aspergillus PacC zinc finger transcription factor requires two proteolytic steps. EMBO J , 21 (6), 1350-1359.

Dowzer, C. E., \& Kelly, J. M. (1989). Cloning of the creA gene from Aspergillus nidulans: a gene involved in carbon catabolite repression. Curr Genet , 15 (6), 457-459.

Eglen Richard M. and Terry Reisine. (2011). Screening for Compounds That Modulate Epigenetic Regulation of the Transcriptome : An Overview. J Biomol Screen 16: 1137

Espeso, E. A., and H. N. Arst, Jr. 2000. On the mechanism by which alkaline pH prevents expression of an acid-expressed gene. Mol. Cell. Biol.20:3355-3363.

Espeso, E. A., Tilburn, J., Arst, H. N., \& Penalva, M. A. (1993). pH regulation is a major determinant in expression of a fungal penicillin biosynthetic gene. EMBO J , 12 (10), 3947-3956. 
FARIA, F.P. (2002).Clonagem, Caracterização e Análise de Expressão de um gene de xilanase(Hxyn2) do fungo Humicola grisea var.thermoidea. Tese de Doutorado apresentada ao Departamento de Biologia Celular da Universidade de Brasília

Golbabapour S, Abdulla MA, and Hajrezaei M. (2011). A concise review on epigenetic regulation: Insight into molecular mechanisms. Intl J Mol Sci 12, 8661-8694.

Greer EL, Blanco MA, Gu L, Sendinc E, Liu J, AristizabalCorrales D, Hsu CH, Aravind L, He C, Shi Y. 2015. DNA methylation on N(6)-adenine in C. elegans. Cell 161:868-78.

Grewal S.I., and Elgin S.C. (2007). Transcription and RNA interference in the formation of heterochromatin. Nature 447, 399-406.

H. V. Lee, S. B. A. Hamid, and S. K. Zain, "Conversion of Lignocellulosic Biomass to Nanocellulose: Structure and Chemical Process," The Scientific World Journal, vol. 2014, Article ID 631013, 20 pages, 2014. doi:10.1155/2014/631013.

He XJ, Chen T, Zhu JK. Regulation and function of DNA methylation in plants and animals. Cell research. 2011;21(3):442-65. doi: 10.1038/cr.2011.23

Hernando-Herraez I, Garcia-Perez R,Sharp AJ, Marques-Bonet T (2015) DNA Methylation:Insights into Human Evolution. PLoS Genet 11(12):e1005661. doi:10.1371/journal.pgen.1005661

Hervas-Aguilar, A., Rodriguez, J. M., Tilburn, J., Arst, H. N., \& Penalva, M. A. (2007). Evidence for the direct involvement of the proteasome in the proteolytic processing of the Aspergillus nidulans zinc finger transcription factor PacC. J Biol Chem , 282 (48), 34735-34747.

Ho, K. L., McNae, I. W., Schmiedeberg, L., Klose, R. J., Bird, A. P., and Walkinshaw, M. D. (2008). MeCP2 binding to DNA depends upon hydration at methyl-CpG. Mol. Cell 29, 525-531. doi: 10.1016/j.molcel.2007.12.028

Holtzapple MT, Cognata M, Shu Y, Hendrickson C. 1990. Inhibition of Trichoderma reesei cellulase by sugars and solvents. Biotechnol Bioeng 36:275- 287

Hrmova, M., Biely, P., \& Vrsanska, M. (1986) Specificity of cellulase and $\beta$-xylanase induction in Trichoderma reesei QM 9414. Arch Microbiol, 144: 307-311.

Häkkinen, M., Sivasiddarthan, D., Aro, N., Saloheimo, M., and Pakula, T.M. (2015) The effects of extracellular $\mathrm{pH}$ and of the transcriptional regulator $\mathrm{PACl}$ on the transcriptome of Trichoderma reesei. Microb Cell Fact 14: 63. 
likura, H.; Takashima, S.; Nakamura, A.; Masaki, H.; Uozumi, T. (1997).Cloning of a gene encoding a putative xylanase with a cellulose-binding domain from Humicola grisea. Biosci Biotechnol Biochem, v. 61, n. 9, p. 1593-5.

IkedaK,VanVu B, Kadotani N, Tanaka M,Murata T, Shiina K, Chuma I,Tosa Y, Nakayashiki H (2013) Is the fungus Magnaporthe losingDNAmethylation? Genetics 195(3):845-855. doi:10.1534/genetics.113.155978

IPEA - INSTITUTO DE PESQUISA ECONÔMICA E APLICADA. Diagnóstico dos Resíduos Orgânicos do Setor Agrossilvopastoril e Agroindústrias Associadas. IPEA, 2012

Izawa, M., O. Takekawa, et al. (2009). "Inhibition of histone deacetylase causes reduction of appressorium formation in the rice blast fungus Magnaporthe oryzae." $\mathrm{J}$ Gen Appl Microbiol 55(6): 489-98.

Jiang, Z., Bail, A. L., Wu, A. (2008) Effect of the thermostable xylanase B (XynB) from Thermotoga maritima on the quality of frozen partially baked bread. Journal of Cereal Science, 47:172-179.

Jin B, Robertson KD. DNA methyltransferases, DNA damage repair, and cancer. Advances in experimental medicine and biology. 2013;754:3-29. doi: 10.1007/978-1-4419-9967-2 1

Joelsson E . Erdei B., Galbe M., Wallberg O. Techno-economic evaluation of integrated firstand second-generation ethanol production from grain and straw. Biotechnol Biofuels (2016) 9:1. DOI 10.1186/s13068-015-0423-8

Jones, P. A. \& Taylor, S. M. (1980). Cellular differentiation, cytidine analogs and DNA methylation. Cell 20:85-93.

Karahoca and Momparler: Pharmacokinetic and pharmacodynamic analysis of 5-aza-2'deoxycytidine (decitabine) in the design of its dose-schedule for cancer therapy. Clinical Epigenetics 2013 5:3.

Karch KR, DeNizio JE, Black BE and Garcia BA (2013) Identification and interrogation of combinatorial histone modifications. Front. Genet. 4:264. doi: 10.3389/fgene.2013.00264.

Kim, J. K., M. Samaranayake, et al. (2009). "Epigenetic mechanisms in mammals." Cell Mol Life Sci 66(4): 596-612.

Ko WH, Yang CH, Lin MJ, Chen CY, Tsou YJ (2011) Humicola phialophoroide sp. nov. from soil with potential for biological control of plant diseases. Bot Stud 52:197-202 .

Kricka,W.; Fitzpatrick, J. and Bond, U. (2014).Metabolic engineering o fyeasts by heterologous enzyme production for degradation ofcellulose and hemicellulose from biomass: a perspective.Front.Microbiol. 5:174. doi:10.3389/fmicb.2014.00174. 
Kuscu C, Zaratiegui M, Kim HS, Wah DA, Martienssen RA, et al. (2014) CRL4-like Clr4 complex in Schizosaccharomyces pombe depends on na exposed surface of Dos1 for heterochromatin silencing. Proceedings of the National Academy of Sciences of the United States of America 111: 1795-1800.

Landraud P, Chuzeville S, Billon-Grande G, Poussereau N, Bruel C (2013) Adaptation to pH and Role of PacC in the Rice Blast Fungus Magnaporthe oryzae. PLoS ONE 8(7): e69236. doi:10.1371/journal.pone.0069236

Lange, L., Bech, L. et al. (2012). The importance of fungi and of mycology for a global development of the bioeconomy IMA Fungus 3(1): 87-92.

Lee DW, Freitag M, Selker EU, Aramayo R (2008) A Cytosine Methyltransferase Homologue Is Essential for Sexual Development in Aspergillus nidulans. PLoS ONE 3(6): e2531. doi:10.1371/journal.pone.0002531

Lewis ZA, Adhvaryu KK, Honda S, Shiver AL, Knip M, et al. (2010) DNA Methylation and Normal Chromosome Behavior in Neurospora Depend on Five Components of a Histone Methyltransferase Complex, DCDC. PLoS Genet 6(11): e1001196. doi:10.1371/journal.pgen.1001196

Lewis ZA, Honda S, Khlafallah TK, Jeffress JK, Freitag M, Mohn F, Schubeler D, Selker EU. Relics of repeat-induced point mutation direct heterochromatin formation in Neurospora crassa. Genome Res.2009;19(3):427-437. doi: 10.1101/gr.086231.108.

Liu Z, Marcucci G, Byrd JC, Grever M, Xiao J, Chan KK. Characterization of decomposition products and preclinical and low dose clinical pharmacokinetics of decitabine (5-aza-2'deoxycytidine) by a new liquid chromatography/tandem mass spectrometry quantification method. Rapid Commun Mass Spectrom.2006;20:1117-26. doi: 10.1002/rcm.2423.

MacCabe, A. P., Van, J. P., Tilburn, J., Arst, H. N., \& Visser, J. (1996). Identification, cloning and analysis of the Aspergillus niger gene pacC, a wide domain regulatory gene responsive to ambient pH. Mol Gen Genet , 250 (3), 367-374.

Mandels, M.; Reese, E. T. (1960).Induction of cellulase in fungi by cellobiose. J Bacteriol, v. 79, p. 816-26.

Maresca A, Zaffagnini M, Caporali L, Carelli V and Zanna C (2015) DNA methyltransferase 1 mutations and mitochondrial pathology: is mtDNA methylated? Front. Genet. 6:90. doi: 10.3389/fgene.2015.00090

MASON, E.W. Annotated account of fungi received at the Imperial Mycologica Institute. List II (fasc.2). Imp. Myc. Inst. Papers, 3: 67, 1933. Apud White \& Downing. Mycologia, 45: 951-963. 1953. 
Mello-De-Sousa, T. M.; Silva-Pereira, I.; Poças-Fonseca, M. J. (2011).Carbon source and pHdependent transcriptional regulation of cellulase genes of Humicola grisea var. thermoidea grown on sugarcane bagasse. Enzyme Microb Technol, v. 48, n. 1, p. 19-26.

Menon, V., Rao, M., 2012. Trends in bioconversion of lignocellulose: biofuels, platform chemicals \& biorefinery concept. Progr. Energy Combust. Sci. 38, 522-550.

MONTI, R.; TERRENZI, H.F. \& JORGE, J.A. Purification of an extracellular xylanaseMottiar, Y., Vanholme, R., Boerjan, W., Ralph, J., Mansfield, S.D. (2015) Designer lignins: harnessing the plasticity of lignification. Current Opinion in Biotechnology, 37, 190-200, doi:10.1016/j.copbio.2015.10.009.

Motwani, T, Poddar, M. et al. (2012). Sir3 and Epigenetic Inheritance of Silent Chromatin in Saccharomyces cerevisiae. Molecular and Cellular Biology 32(14):2784-2793.

Nair et al:: Study of cell differentiation by phylogenetic analysis using histone modification data. BMC Bioinformatics 2014 15:269.

Nortey, T. N., J. F. Patience, J. S. Sands, N. L. Trottier, and R. T. Zijlstra. 2008. Effects of xylanase supplementation on digestibility and digestible content of energy, amino acids, phosphorus, and calcium in wheat by-products from dry milling in grower pigs. J. Anim. Sci. 86:3450-3464.

Oh, Gabriel et al. DNA Modification Study of Major Depressive Disorder: Beyond Locus-byLocus Comparisons.Biological Psychiatry(2014).

Okamoto et al.: Bioconversion of xylose, hexoses and biomass to ethanol by a new isolate of the white rot basidiomycete Trametes versicolor. SpringerPlus 2014 3:121.

Oliveira GS, Ulhoa CJ, Silveira MH, Andreaus J, Silva-Pereira I, Pocas-Fonseca MJ, et al. An alkaline thermostable recombinant Humicola grisea var. thermoidea cellobiohydrolase presents bifunctional (endo/exoglucanase) activity on cellulosic substrates. World J Microbiol Biotechnol. 2013;29(1):19-26. doi:10.1007/s11274-012-1153-8

OlIVEIRA, A.R.; XIMENES, E.A. \& FELIX, C.R. Amylolytic activity of Humicola sp. An. Acad. Bras., 63: 409-414. 1991.

Oliverio, A. M., and Katz, L. A. (2014). The dynamic nature of genomes across the tree of life. Genome Biol. Evol. 6, 482-488. doi: 10.1093/gbe/evu024.

Penalva, M. A., and H. N. Arst, Jr. 2002. Regulation of gene expression by ambient pH in filamentous fungi and yeasts. Microbiol. Mol. Biol. Rev.66:426-446. 
Poças-Fonseca, M. J., B. D. Lima, et al. (1997). "Humicola grisea var. thermoidea cbh1.2: A new gene in the family of cellobiohydrolases is expressed and encodes a cellulose-binding domain-less enzyme." J Gen Appl Microbiol 43(2): 115-120.

Poças-Fonseca, M. J., I. Silva-Pereira, et al. (2000). "Substrate-dependent differential expression of Humicola grisea var. thermoidea cellobiohydrolase genes." Can J Microbiol 46(8): 749-52.

Poças-Fonseca, M. J., Mello-de-Sousa, T. M. \& Aguiar, S. M. (2008). pH-Related transcriptional regulation of lignocellulolytic enzymes and virulence factors genes in fungi. In: Current Advances in Molecular Mycology. Y. Gherbawy, R. L. Mach \& M. Rai (Eds.). Nova Science Publishers, Inc.

Polizeli, M. L., A. C. Rizzatti, et al. (2005). "Xylanases from fungi: properties and industrial applications." Appl Microbiol Biotechnol 67(5): 577-91.

Portnoy et al.: The CRE1 carbon catabolite repressor of the fungus Trichoderma reesei: a master regulator of carbono assimilation. BMC Genomics 2011 12:269.

POTHIRAJ, C.; KANMANI, P.; BALAJI, P. (2006). Bioconversion of lignocellulose materials. Mycobiol.34: 159-165.

Qian Kang, Lise Appels, Tianwei Tan, and Raf Dewil, "Bioethanol from Lignocellulosic Biomass: Current Findings Determine Research Priorities," The Scientific World Journal, vol. 2014, Article ID 298153, 13 pages, 2014. doi:10.1155/2014/298153

R. Meneses, G.I. Varela, H. Flores, Evaluating the use of Atriplex nummularia hay on feed intake, growth, and carcass characteristics of creole kids, Chilean, J. Agric. Res. 72 (1) (2012) 74-79. http://dx.doi.org/10.4067/S0718-58392012000100012

Rogstad DK, Herring JL, Theruvathu JA, Burdzy A, Perry CC, Neidigh JW, Sowers LC. Chemical decomposition of 5-aza-2'-deoxycytidine (Decitabine): kinetic analyses and identification of products by NMR, HPLC, and mass spectrometry. Chemical research in toxicology. 2009;22(6):1194-204.

Rollins, J. A.; Dickman, M. B. (2001).pH signaling in Sclerotinia sclerotiorum: identification of a pacC/RIM1 homolog. Appl Environ Microbiol, v. 67, n. 1, p. 75-81.

Rose, C. M., van den Driesche, S., Sharpe, R. M., Meehan, R. R., \& Drake, A. J. (2014). Dynamic changes in DNA modification states during late gestation male germ line development in the rat. Epigenetics \& chromatin, 7, 19. 
Ruijter, G. J.; Visser, J. (1997).Carbon repression in Aspergilli. FEMS Microbiol Lett, v. 151, n. 2, p. 103-14.

SALOHEIMO, A.; ARO, N.; ILMÉN, M. \& PENTTILÄ, M. Isolation of the ace1 gene encoding a Cys2-His2 transcription factor involved in regulation of activity of the cellulase promoter $c b h 1$ of Trichoderma reesei. J. Biol. Chem., 275: 5817-5825. 2000.

Selker E.U., Tountas N.A., Cross S.H., Margolin B.S., Murphy J.G., Bird A.P., Freitag M. The methylated component of the neurospora crassa genome. Nature. 2003;422:893-897. doi: 10.1038/nature01564.

Selvig, K.; Alspaugh, J. A. (2011).pH Response Pathways in Fungi: Adapting to Host-derived and Environmental Signals. Mycobiology, v. 39, n. 4, p. 249-56.

Sinclair SH, Rennoll-Bankert KE and Dumler JS (2014) Effector bottleneck: microbial reprogramming of parasitized host cell transcription by epigenetic remodeling of chromatin structure. Front. Genet. 5:274. doi: 10.3389/fgene.2014.00274.

Smith L. G. (2001). Plant cell division: building walls in the right places. Nat. Rev. Mol. Cell Biol. 233-39 10.1038/35048050

Strauss, J. and Reyes-Dominguez, Y. (2011) Regulation of secondary metabolism by chromatin structure and epigenetic codes Fungal Genetics and Biology 48: 62-69.

Strauss, J., Horvath, H. K., Abdallah, B. M., Kindermann, J., Mach, R. L., \& Kubicek, C. P. (1999). The function of CreA, the carbon catabolite repressor of Aspergillus nidulans, is regulated at the transcriptional and post-transcriptional level. Mol Microbiol, 32 (1), 169-178.

Strauss, J., R. L. Mach, S. Zeilinger, G. Hartler, G. Stoffler, M. Wolschek, and C. P. Kubicek. 1995. Cre1, the carbon catabolite repressor protein from Trichoderma reesei. FEBS. Lett. 376:103-107.

Stresemann, C. and Lyko, F. (2008), Modes of action of the DNA methyltransferase inhibitors azacytidine and decitabine. Int. J. Cancer, 123: 8-13. doi: 10.1002/ijc.23607

Suarez, T., \& Penalva, M. A. (1996). Characterization of a Penicillium chrysogenum gene encoding a PacC transcription factor and its binding sites in the divergent $p c b A B-p c b C$ promoter of the penicillin biosynthetic cluster. Mol Microbiol , 20 (3), 529-540.

Sun J, Glass NL (2011) Identification of the CRE-1 cellulolytic regulon in Neurospora crassa. PLoS One 6-e25654. 
Takashima, S., A. Nakamura, et al. (1996). "Cloning, sequencing, and expression of the cellulase genes of Humicola grisea var. thermoidea." J Biotechnol 50(2-3): 137-47.

Takashima, S., A. Nakamura, et al. (1997). "Cloning, sequencing, and expression of a thermostable cellulase gene of Humicola grisea." Biosci Biotechnol Biochem 61(2): 245-50.

Takashima, S., A. Nakamura, et al. (1999). "Molecular cloning and expression of the novel fungal beta-glucosidase genes from Humicola grisea and Trichoderma reesei." J Biochem 125(4): 728-36.

Takashima, S., H. likura, et al. (1999). "Comparison of gene structures and enzymatic properties between two endoglucanases from Humicola grisea." J Biotechnol 67(2-3): 85-97.

Takashima, S., Nakamura, A., Hidaka, M., Masaki, H., \& Uozumi, T. (1998). Isolation of the creA gene from the cellulolytic fungus Humicola grisea and analysis of CreA binding sites upstream from the cellulase genes. Biosci Biotechnol Biochem , 62 (12), 2364-2370.

TAKASHIMA, S.; NAKAMURA, A.; MASAKI, H. \& TAKESHI, U. Purification and Characterization of Cellulases from Humicola grisea. Biosci. Biotech. biochem., 60: 77-82. 1995.

Tam WL1, Weinberg RA (2013). The epigenetics of epithelial-mesenchymal plasticity in cancer. Nat Med. 19: 1438-1449.

Tamayo, E. N.; Villanueva, A.; Hasper, A. A.; De Graaff, L. H.; Ramon, D.; Orejas, M. (2008).CreA mediates repression of the regulatory gene $x \ln R$ which controls the production of xylanolytic enzymes in Aspergillus nidulans. Fungal Genet Biol, v. 45, n. 6, p. 984-93.

Tamburini, E.; Costa, S.; Marchetti, M.G.; Pedrini, P. Optimized Production of Xylitol from Xylose Using a Hyper-Acidophilic Candida tropicalis. Biomolecules 2015, 5, 1979-1989.

Tilburn, J., Sarkar, S., Widdick, D. A., Espeso, E. A., Orejas, M., Mungroo, J., et al. (1995). The Aspergillus PacC zinc finger transcription factor mediates regulation of both acid- and alkalineexpressed genes by ambient pH. EMBO J , 14 (4), 779-790.

Trevisan, G. L., Oliveira, E. H. D., Peres, N. T. A, Cruz, A. H. S., Martinez-Rossi, N. M., \& Rossi A.(2011) .Transcription of Aspergillus nidulans pacC is modulated by alternative RNA splicing of palB. FEBS Letters, 585:3442-3445.

Waddington C. (1942). The epigenotpye. Endeavour 1 18-20

van Peij, N. N.; Gielkens, M. M.; de Vries, R. P.; Visser, J., \& de Graaff, L. H. (1998). The transcriptional activator XInR regulates both xylanolytic and endoglucanase gene expression in Aspergillus niger. Appl Environ Microbiol , 64 (10), 3615-3619. 
van West, P., S. J. Shepherd, et al. (2008). "Internuclear gene silencing in Phytophthora infestans is established through chromatin remodelling." Microbiology 154(Pt5): 1482-90.

Wang, Q.; Szaniszlo, P. J. (2009).Roles of the $\mathrm{pH}$ signaling transcription factor PacC in Wangiella (Exophiala) dermatitidis. Fungal Genet Biol, v. 46, n. 9, p. 657-66.

Vautard, G., P. Cotton, and M. Fevre. 1999. The glucose repressor CRE1 from Sclerotinia sclerotiorum is functionally related to CREA from Aspergillus nidulans but not to the Mig proteins from Saccharomyces cerevisiae. FEBS Lett. 453:54-58.

Williams R. B., Henrikson J. C., Hoover A. R., Lee A. E., Cichewicz R. H. (2008). Epigenetic remodeling of the fungal secondary metabolome. Org. Biomol. Chem. 6 1895-1897.doi: 10.1039/b804701d

Yu, R., Jih, G., Iglesias, N. \& Moazed, D. Determinants of heterochromatic siRNA biogenesis and function. Mol Cell 53, 262-276, doi:10.1016/j.molcel.2013.11.014 (2014).

Zemach, A., and Zilberman, D. (2010). Evolution of eukaryotic DNA methylation and the pursuit of safer sex. Curr. Bio. 20, R780-R785

Zhang G, Huang H, Liu D, Cheng Y, Liu X, Zhang W, Yin R, Zhang D, Zhang P, Liu J, et al. 2015. N(6)-methyladenine DNA modification in Drosophila. Cell 161:893-906.

Zimmermann, A. L.; Terenzi, H. F.; Jorge, J. A. (1990).Purification and properties of an extracellular conidial trehalase from Humicola grisea var. thermoidea. Biochim Biophys Acta, v. 1036 , n. 1 , p. $41-6$.

Zutz C, Gacek A, SulyokM,WagnerM, Strauss J, Rychli K (2013) Small chemical chromatin effectors alter secondary metabolite production in Aspergillus clavatus. Toxins (Basel) 5(10):1723-1741 